\title{
29. KARST MORPHOLOGY AND DIAGENESIS OF THE TOP OF ALBIAN LIMESTONE PLATFORMS, MID-PACIFIC MOUNTAINS ${ }^{1}$
}

\author{
Edward L. Winterer, ${ }^{2}$ Robert van Waasbergen, ${ }^{3}$ Jacqueline Mammerickx, ${ }^{2}$ and Steven Stuart ${ }^{2}$
}

\begin{abstract}
The upper surface of the Albian platform limestone on many Mid-Pacific Mountains (MPM) guyots, as shown by multibeamsonar, bathymetric data, and seismic-reflection data from where pelagic sediments have buried the Albian platform limestone, shows that the top of the limestone sequence has been sculptured by streams, by waves, and by dissolution during an episode of emergence to heights of as much as $180 \mathrm{~m}$ above sea level. Seismic-reflection profiles show that the surface is arched over the buried volcanic basement, reflecting progressive differential compaction of the limestone section over erosional relief on the basement. This compaction began during early stages of burial of limestone layers and continued after final drowning of the platform. On some guyots, differential erosion left a prominent perimeter rim several tens of meters high. This atoll-like erosional form was drowned in post-Albian, pre-mid-Turonian time, with no further accumulation of platform limestone. Petrographic and stable-isotopic studies of samples recovered in drill holes in the upper parts of the platform limestone on Allison and Resolution guyots show dissolution cavities tens of meters below the top of the limestone, some filled with pelagic sediments and others still open and lined with stalagmite-like calcite structures and cements showing evidence of accumulation in vadose environments.
\end{abstract}

\section{INTRODUCTION}

New data on the Mid-Pacific Mountains (MPM) (Fig. 1), amassed during Ocean Drilling Program (ODP) Leg 143 (Shipboard Scientific Party, 1993a, 1993b, 1993c), provide the basis for a new assessment of the morphology of the MPM guyots, especially of the morphology of the top surface of the Lower Cretaceous carbonate platform. As revealed during previous seismic-reflection and multibeam surveys (published in part in Shipboard Scientific Party, 1973; Heezen et al., 1973; Nemoto and Kroenke, 1985; van Waasbergen and Winterer, 1993), this surface is not flat, as would be expected from a simple drowning of a shallow-water carbonate platform; instead, it shows both local relief and, on most guyots, a broad doming of the upper surface. The top limestone surface is generally buried beneath a mound of younger pelagic sediments that seal the local relief on the unconformity. Winterer and Metzler (1984) ascribed the local relief to erosional topography developed during an episode of emergence in the mid-Cretaceous. From multibeam bathymetric data obtained on a later survey, van Waasbergen and Winterer (1993) extended the emergence hypothesis to many Lower Cretaceous guyots elsewhere in the northwest Pacific.

Evidence presented herein bears strongly on the question of the origin of atoll morphology. Many guyots in the northwest Pacific, including some within the MPM, have a pronounced perimeter rim, and thus have the superficial morphology of a modern coral atoll. Since Darwin (1842) first put forward his hypothesis on the origin of coral reefs, it has been widely accepted that upward growth of an original fringing reef around a subsiding volcanic island will result successively in a barrier reef and finally in an atoll, of roughly the same diameter as the original island. The hypothesis depends on upward growth at the platform margin being greatly advantaged as compared to more interior zones. Embellishments on this hypothesis (e.g., Daly, 1934; Hoffmeister and Ladd, 1944; Keunen, 1950) postulate bevelling during lowered sea level in the Pleistocene, and then renewed upward growth of a rim, owing to most favorable growth conditions at the edge of a platform. The simple upward-growth hy-

\footnotetext{
${ }^{1}$ Winterer, E.L., Sager, W.W., Firth, J.V., and Sinton, J.M. (Eds.), 1995. Proc. ODP. Sci. Results, 143: College Station, TX (Ocean Drilling Program).

${ }_{2}^{2}$ Scripps Institution of Oceanography, La Jolla, CA 92093, U.S.A.

${ }^{3}$ University of Tulsa, Tulsa, OK 74104, U.S.A.
}

pothesis has been challenged, most recently and vigorously by Purdy (1974), who offered an alternative hypothesis that the atoll form of modern reefs is inherited from a rimmed erosional landscape developed during one or more episodes of subaerial emergence of a carbonate bank. Upon rapid resubmergence, the reef community established itself on the rim and grew upward apace with subsidence.

To test these contrasting hypotheses and to try to understand the origin of the domical arching, we analyzed survey data from eight different guyots in different parts of the MPM as well as data from drilling at Allison Guyot (Site 865) and Resolution Guyot (Sites 866-868).

Of particular interest, in the light of morphologic evidence for subaerial exposure of guyot summits in the Mid-Pacific Mountains, are intervals in the materials collected from cores at the drill sites on Allison and Resolution guyots, in which visible, open and cementand sediment-filled fractures and cavities occur, as well as intervals of unusual cementation. Samples from such intervals were collected for petrographic and geochemical analysis, and results from these studies are reported herein and interpreted.

Discussion of the possible causes and larger implications of a regional mid-Cretaceous emergence episode is beyond the scope of this chapter, but these broader questions are examined in the synthesis chapter in this volume.

\section{Morphologic Data}

Of the 50-odd guyots in the MPM (Fig. 1), survey data for only about one fourth of these are adequate to define the morphology of the upper surface of the Lower Cretaceous shallow-water platform limestone in any detail. On some guyots, the platform limestone is widely exposed at the seafloor, and for a few of these, there are multibeamecho-sounder bathymetric surveys. On many other guyots, the limestone is partly to wholly blanketed by a cover of younger pelagic sediments, and for these a network of good-quality seismic profiles is required to reveal relief features on the unconformity. We first discuss data from eight guyots for which there are instructive data, namely, Cape Johnson, Allison, Resolution, "Jacqueline," "Renard," "Heezen," Horizon (at Deep Sea Drilling Project [DSDP] Site 171) and Sio Guyots (names within quotation marks are unofficial, i.e., not recognized and approved by a national or international authority for geographic names. These names are nonetheless in widespread use on charts and in scientific publications). Second, we discuss data from other MPM 
A

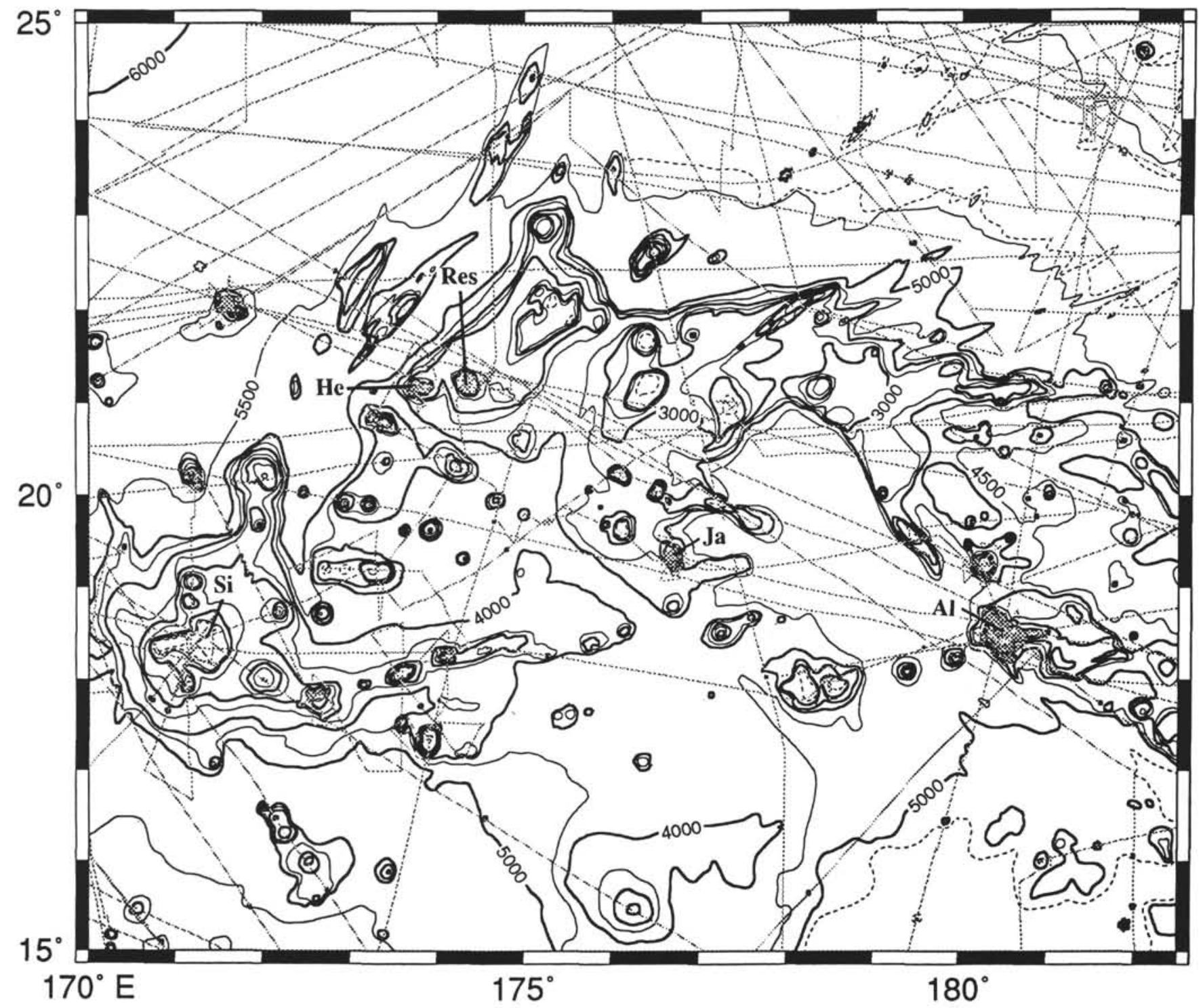

Figure 1. Bathymetry of Mid-Pacific Mountains. A. Western part. B. Eastern part. Contour interval $=1000 \mathrm{~m}$, with additional 500-and $100-\mathrm{m}$ contours shown where appropriate. Tracks of precision echo-sounding lines shown. Guyots mentioned in the text have been labeled. From west to east, these are $\mathrm{Si}=\mathrm{Sio}, \mathrm{He}=$ "Heezen," Res = Resolution, Ja = "Jacqueline," $\mathrm{Al}=$ Allison, $\mathrm{CJ}=$ Cape Johnson, Ren = "Renard," Ho = Horizon. No contours are shown in the northeast corner of B, near the Hawaiian seamounts.

guyots for which we have only a few, or even only one, survey line. For each guyot, we introduce the relevant data on the morphology of the upper surface of the limestone and then go on to an interpretation. In a later section, we pull the data together into a synthesis and a model for the evolution of MPM guyot morphology.

Two major features of the upper surface of the limestone require explanation. The broad-scale relief on many MPM guyots is the domeor arch-like shape of the surface. Instead of the nearly flat surface that would be expected for the uppermost limestone strata, which dredging and drilling show were deposited within a few meters of sea level, the surface arches over the central part of the guyot, forming an irregular, but broadly domical surface with its highest parts from 20 to as much as $200 \mathrm{~m}$ above the level of the edge of the break in slope at the perimeter of the summit area (Fig. 2). We present evidence herein that the form of this surface is mainly the result of differential compaction of platform strata over buried volcanic basement relief.
The second feature of the limestone surface on many guyots is that it has been shaped by erosion. The most common erosional form in this relief is a discontinuous ridge that forms a rim around the perimeter, standing 20 to $60 \mathrm{~m}$ higher than an adjacent, inner ring of elongate depressions, or moats, that parallel the rim ridges. It is this girdle of perimeter ridges that gives many guyots their atoll-like form. Most guyots in the MPM not having a perimeter rim have other major erosional forms on the upper surface of the limestone, and some of these are described in detail below.

The limestone surface on many guyots is further engraved by relatively small-scale relief in the form of oval depressions resembling sinkholes and dolines as much as $180 \mathrm{~m}$ deeper than their immediate surroundings. Additional small-scale features include local cliffs, buttes, mesas, and, on at least one guyot, a dendritic drainage pattern. We ascribe the rim and moat, and the other small-scale relief to erosion by streams, by dissolution, and by waves during a time of 


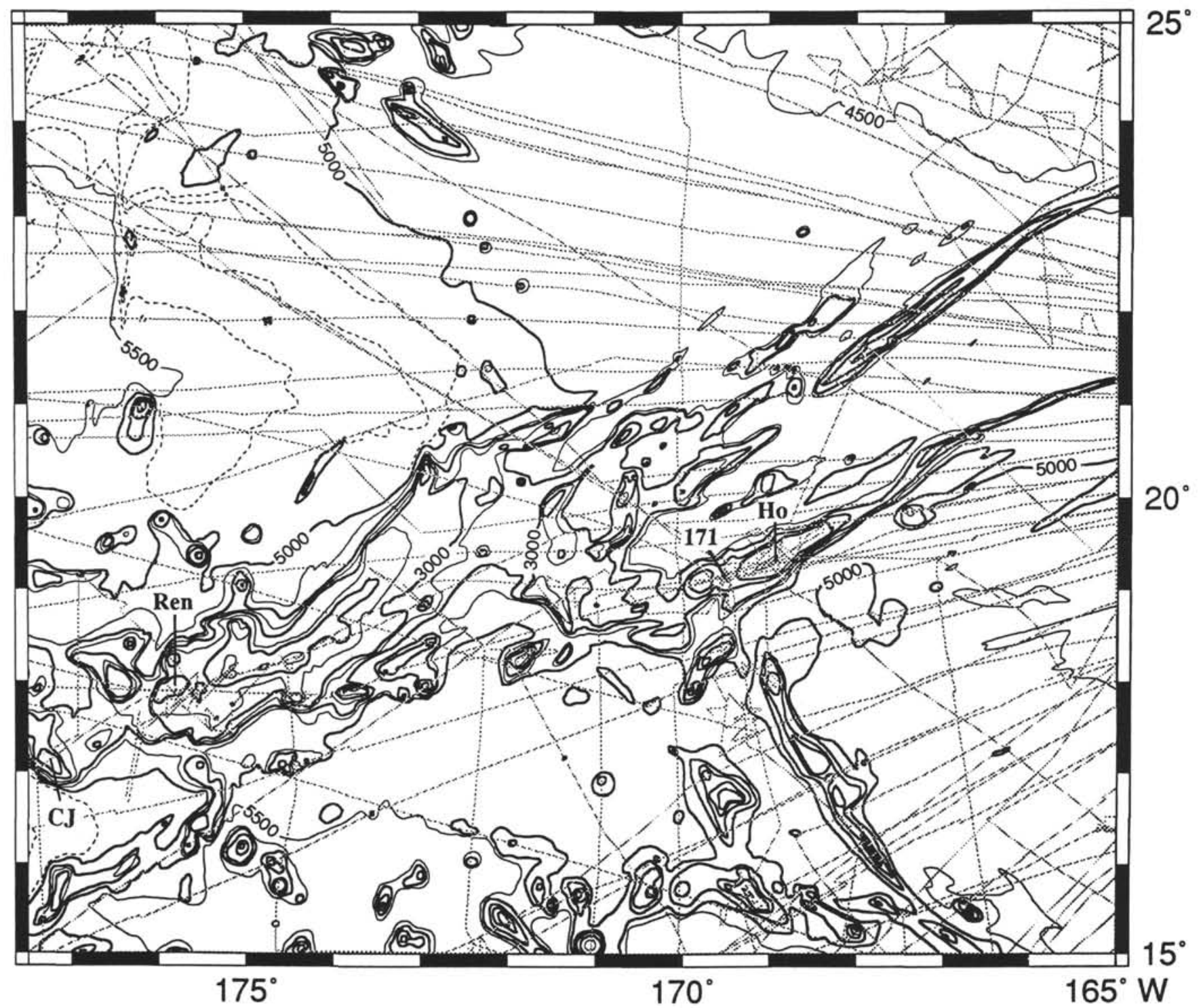

Figure 1 (continued).

emergence of the guyot summit, following deposition of the last shallow-water limestone strata.

\section{Petrographic and Geochemical Methods and Data}

In addition to the morphologic data, we here present new data on the petrology and geochemistry of the uppermost parts of the shallowwater limestone strata drilled in the MPM during ODPLeg 143. These data provide direct, material evidence about the diagenetic history of the upper limestone strata. We have no comparable material from other guyots in MPM, except for Site 171 at Horizon Guyot, for which there are petrographic descriptions of the limestones in the "Site 171" chapter (Shipboard Scientific Party, 1973).

The upper portions of the shallow-water limestone sections drilled at Allison (Site 865) and Resolution guyots (Sites 865, 866, 867, and 868 ) yielded very poor core recovery (typically, less then $1 \%$ ). In general, samples were recovered as 1 - to $4-\mathrm{cm}$-sized rounded fragments, mostly in the core catcher. Limestone facies include abundant wacke- stone and mudstone, as well as fossiliferous packstone, all of Albian age. These samples form the only direct, material information on the stratigraphy and diagenetic history the upper parts of the sections.

For petrographic observations, standard petrographic thin sections were prepared from available limestone samples. These were studied with a Nikon petrographic microscope with a $35-\mathrm{mm}$ camera attachment.

Different components from within the samples were subsampled with a fine-tipped dental drill. Sample sizes ranged from 10 to $100 \mu \mathrm{g}$. These were placed in small copper vessels and roasted at $375^{\circ} \mathrm{C}$ for 1 $\mathrm{hr}$, under vacuum. The samples were reacted with dry phosphoric acid at $90^{\circ} \mathrm{C}$, under vacuum, using a common-vat reaction container. The gas released by the reaction was collected, and water and any other noncondensible substances removed in an automated vacuum line with liquid-nitrogen traps. The clean $\mathrm{CO}_{2}$ gas was then allowed to enter a mass spectrometer, and the ratio of ${ }^{18} \mathrm{O}$ to ${ }^{16} \mathrm{O}$ and ${ }^{13} \mathrm{C}$ to ${ }^{12} \mathrm{C}$ was measured and compared to that of the reference gas, which has a known isotopic ratio relative to PDB. The entire process from reac- 


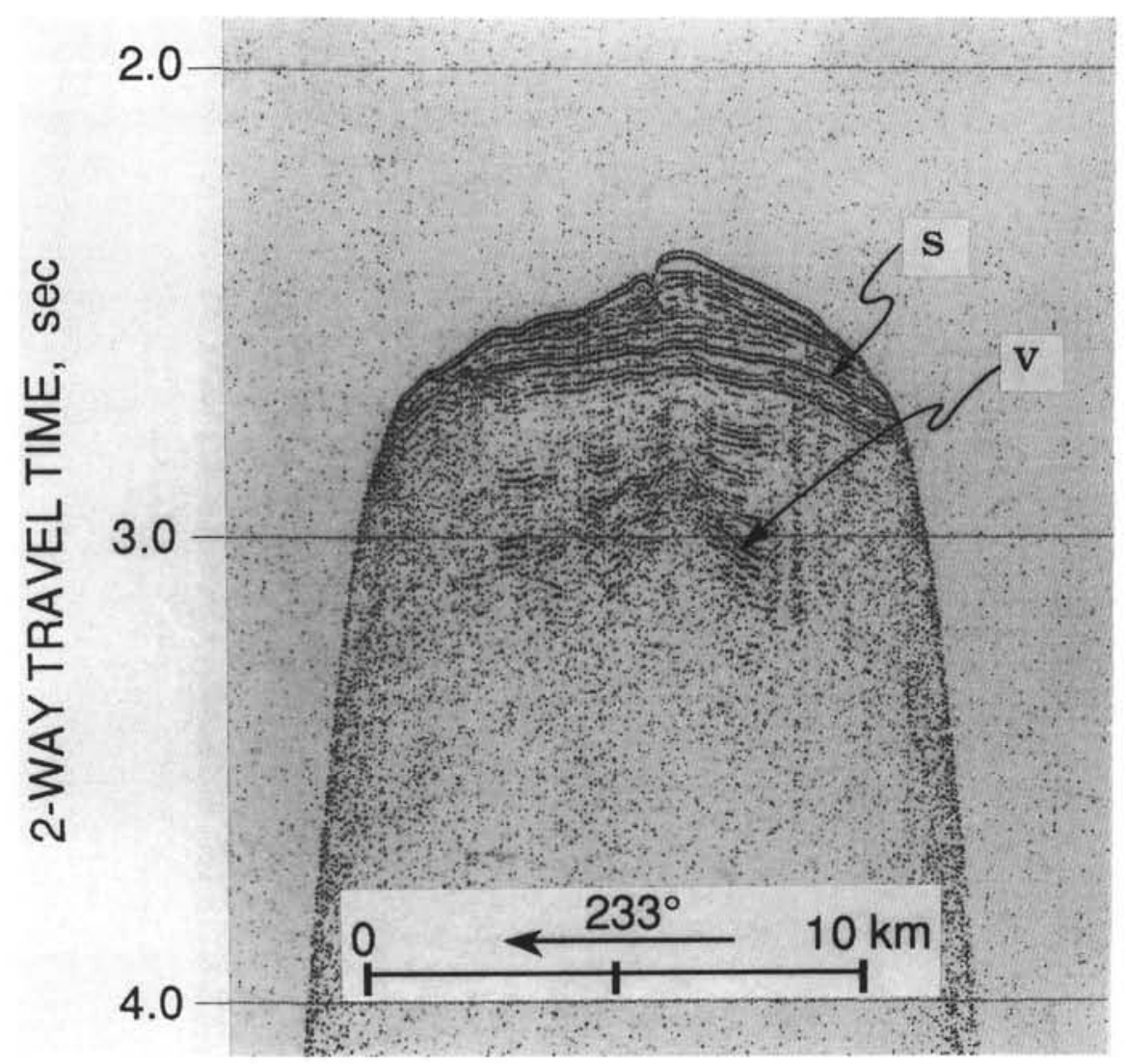

Figure 2. Seismic-reflection profile across Cape Johnson Guyot showing domical surface (s) of platform limestone beneath the cover of pelagic sediments. A central volcanic hill $(v)$ is buried beneath the platform strata, which onlap the volcanic hill slopes. Near the base of the section, onlapping layers may include volcanic detritus derived from erosion of still-exposed parts of the volcanic hill, and these layers may have interfingered with nonmarine sediments that had initial seaward dips, at least in parts close to the hill. On the other hand, as judged from drilling at Site 865 on Allison Guyot (Shipboard Scientific Party, 1993a), higher layers, above the top of the buried hill, are nearly pure shallow-water limestone and were originally deposited horizontally. Their present-day attitudes must therefore result from post-depositional deformation. Because upper layers of limestone dip progressively less steeply than lower layers, the dip of the layers is attributed in large measure to progressive differential compaction over the rigid volcanic hill. Compaction continued after the deposition of the uppermost limestone layers, giving the surface of unconformity its arched shape. Middle Cretaceous shallow-water fossils were dredged from the upper slopes of this guyot by Hamilton (1950),

tion to measurement was done automatically, through a computercontrolled vacuum line, thus ensuring a high degree of consistency in sample treatment. Isotopic ratios measured in this way are thought to be reproducible to $0.2 \%$.

\section{Allison Guyot}

\section{Morphology of Summit Area}

The generalized bathymetry of the upper part of the Allison Guyot (Fig. 3; Al in Fig. 1A) shows a broad mound of pelagic sediments over the top of the guyot and steep upper slopes around the perimeter. A cluster of small volcanic cones encrusts the eastern, panhandle end of the guyot, and a small satellite guyot stands just south of the south margin. The guyot was drilled during ODPLeg 143 at Site 865, where about $730 \mathrm{~m}$ of upper Albian shallow-water limestone, intruded by basaltic sills in its lower part, was drilled beneath a cover of younger pelagic sediments (Shipboard Scientific Party, 1993a). Basement was not reached; instead, the drilling stopped in a series of basaltic sills intercalated in shallow-water marl and limestone strata.

The upper surface of the platform limestone is partly exposed around the perimeter of the guyot, but over the main, central region, the surface is buried beneath pelagic sediments. As shown on the contour map (Fig. 4), this surface of unconformity is broadly warped. The surface forms a ridge that trends southward from the northern "cape" of the guyot to a junction with an east-trending ridge that parallels the southern margin of the guyot. From the ridge crests, the surface of unconformity slopes down about $200 \mathrm{~m}$ to the east and northeast into a large closed depression.

The undulating surface is engraved by a now-buried drainage channels that flowed into the closed depression toward the northeast and by a valley that exited to the outer slopes of the guyot toward the southwest. In cross section, the unconformity can be seen to truncate reflection surfaces (bedding) in the underlying platform limestone (Figs. 5, 6, and 7). In some places, the surface rises in sharp steps (Fig. 7), marking lines of buried steep slopes or cliffs that in some places surround mesas or buttes.

Along much of the northern margin of the guyot, as revealed in the multibeam-sonar bathymetry (Fig. 4), the perimeter is marked by a series of narrow ridges that are paralleled closely on their interior side by elongate closed depressions or moats, typically 80 to 120 m deeper than the perimeter ridges. Generally, seismic reflections beneath the perimeter ridges are incoherent, but in a few places (Figs. 8 and 9), reflectors with a gentle seaward dip can be traced across the moat and through or beneath the ridge.

Most of the depressions or moats behind the perimeter ridges are shallow, but one closed depression, on the east side of the northern cape of the guyot, extends at least $180 \mathrm{~m}$ vertically downward from the adjacent top of the platform. By contrast, along the western and southwestern margins of the guyot, the edge of the platform is marked simply by a prominent break in slope, from generally flat on the platform to slopes of about $20^{\circ}$ below. Along the southeast margin, the original form of the edge of the platform has been destroyed by large-scale slumping. 


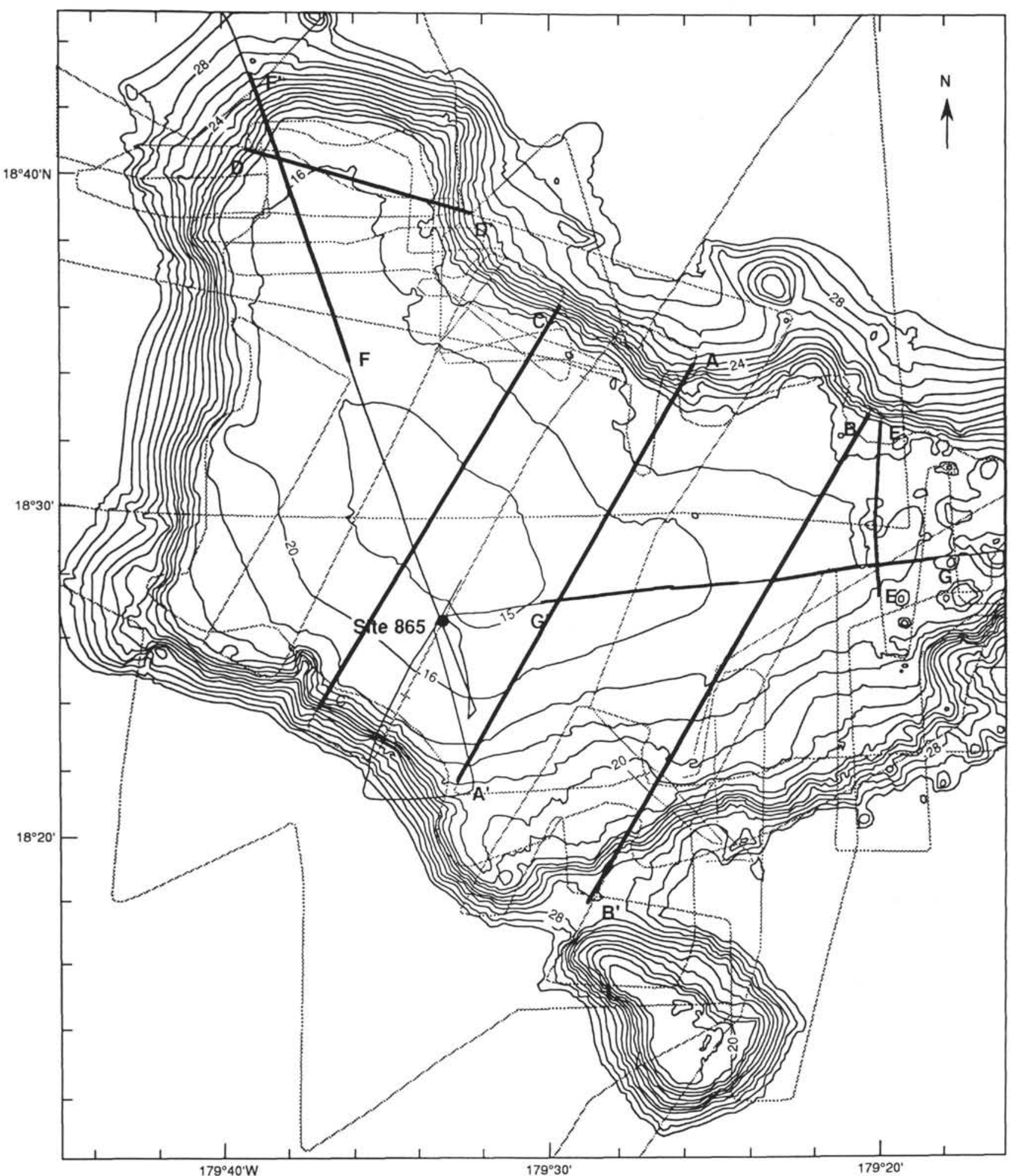

Figure 3. Generalized bathymetry of Allison Guyot, from surveys by Thomas Washington during Scripps Institution of Oceanography (SIO) cruises Roundabout, Leg 10, and Aries, Leg 5, and from JOIDES Resolution during Leg 143. Contour interval $100 \mathrm{~m}$. Track lines of survey vessels shown, with thicker lines indicating portions of tracks shown, for which seismic-reflection profiles are shown in subsequent figures.

The depth to the break in slope at the outer margin of the platform varies irregularly around the platform perimeter, from about $1700 \mathrm{~m}$ along the north and west margins, to about $1800 \mathrm{~m}$ along the eastern parts of the northeast margin. Near the eastern end of the guyot, where young volcanoes (about $85 \mathrm{Ma}$ according to radiometric data from Duncan and Pringle, this volume) have been emplaced, the volcanoes are surrounded by current-formed moats in the younger pelagic sediments (Fig. 10).

We interpret the stepped topography on the unconformity in the interior parts of the guyot to be the result of differences in erosional resistance of limestone strata, and the narrow closed depressions to be sinkholes or dolines that developed by dissolution during a period 


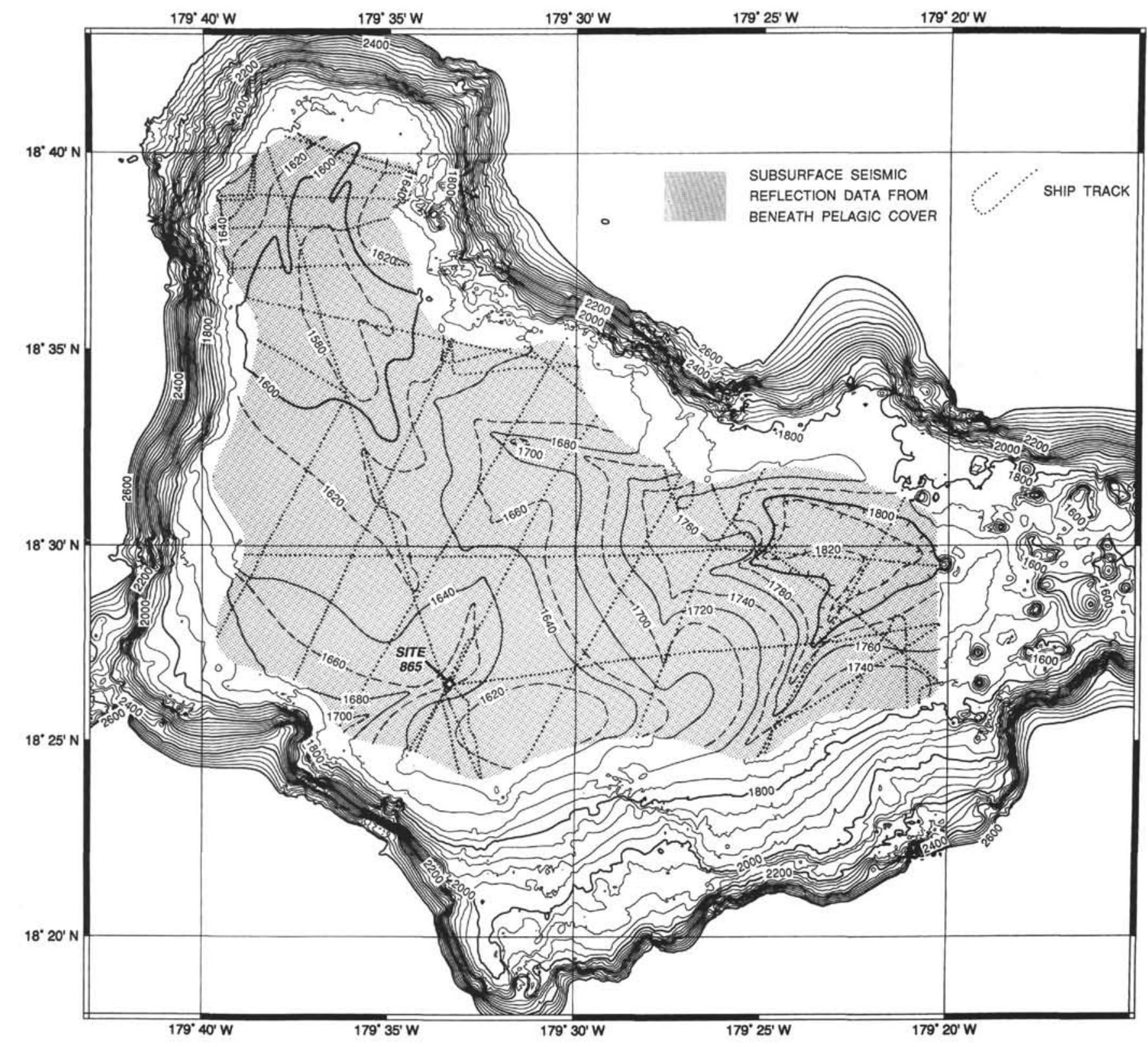

Figure 4. Contour map of the upper surface of the Lower Cretaceous platform limestone on Allison Guyot. Over the central region of the guyot the surface is covered by pelagic sediments (stippled pattern). Depths from multibeam and 3.5-kHz echo-sounder, and seismic survey data collected by Thomas Washington during SIO cruises Roundabout, Leg 10, and Aries, Leg 5, and from JOIDES Resolution during Leg 143. Contour interval, 40 m, with additional 20-m contours shown beneath pelagic cover. A sound velocity of $1600 \mathrm{~m} / \mathrm{s}$ was used for the pelagic sediments. Depths were adjusted at crossings to match depths measured by multibeam echo-sounding during Roundabout, Leg 10, cruise. Dotted lines show seismic-reflection profiler tracks used when constructing the map.

of emergence of the guyot. The 180 -m depth of the sinkhole on the northeast margin gives an estimate of the minimum depth of subaerial dissolution erosion, and thus of the minimum relative fall of sea level.

Evidence supporting an erosional, as opposed to a "reefal," constructional origin for the perimeter rims and moats, comes from seismicreflection profiles (Figs. 8 and 9) that show reflectors beneath the rim continuous with reflectors in the interior of the platform (Fig. 8) and reflectors within the rim truncated by erosion at the moat (Fig. 9).

The broad relief on the unconformity follows in a subdued way the relief of the deeply-buried, underlying acoustic basement seen on seismic-reflection profiles (e.g., Figs 5, 6, and 11). In two areas especially, the originally flat-lying platform limestone layers are bent into anticlinal arches and pelagic sediments are draped across the arches. One of these arches trends west across the southern part of the platform from near the cluster of volcanic cones at the eastern, panhandle end of the guyot (Fig. 6). The arch shows about $150 \mathrm{~m}$ of topographic relief on its north flank and about $200 \mathrm{~m}$ of structural relief with respect to the upper limestone reflectors. Nearly the whole limestone section beneath the south slope of this anticline has been erosionally truncated and then partly buried beneath pelagic sediments, which onlap the arch from the north (Fig. 5). The other arch is beneath the northern cape of the guyot (Fig. 7) and shows about $60 \mathrm{~m}$ of both topographic and structural relief with respect to upper reflectors in the platform limestone.

The arching of the limestone reflectors beneath the northern cape and across the southern part of the platform is interpreted as mainly resulting from the combined effects of depositional onlap and differential compaction of sediments over original relief on volcanic ridges 


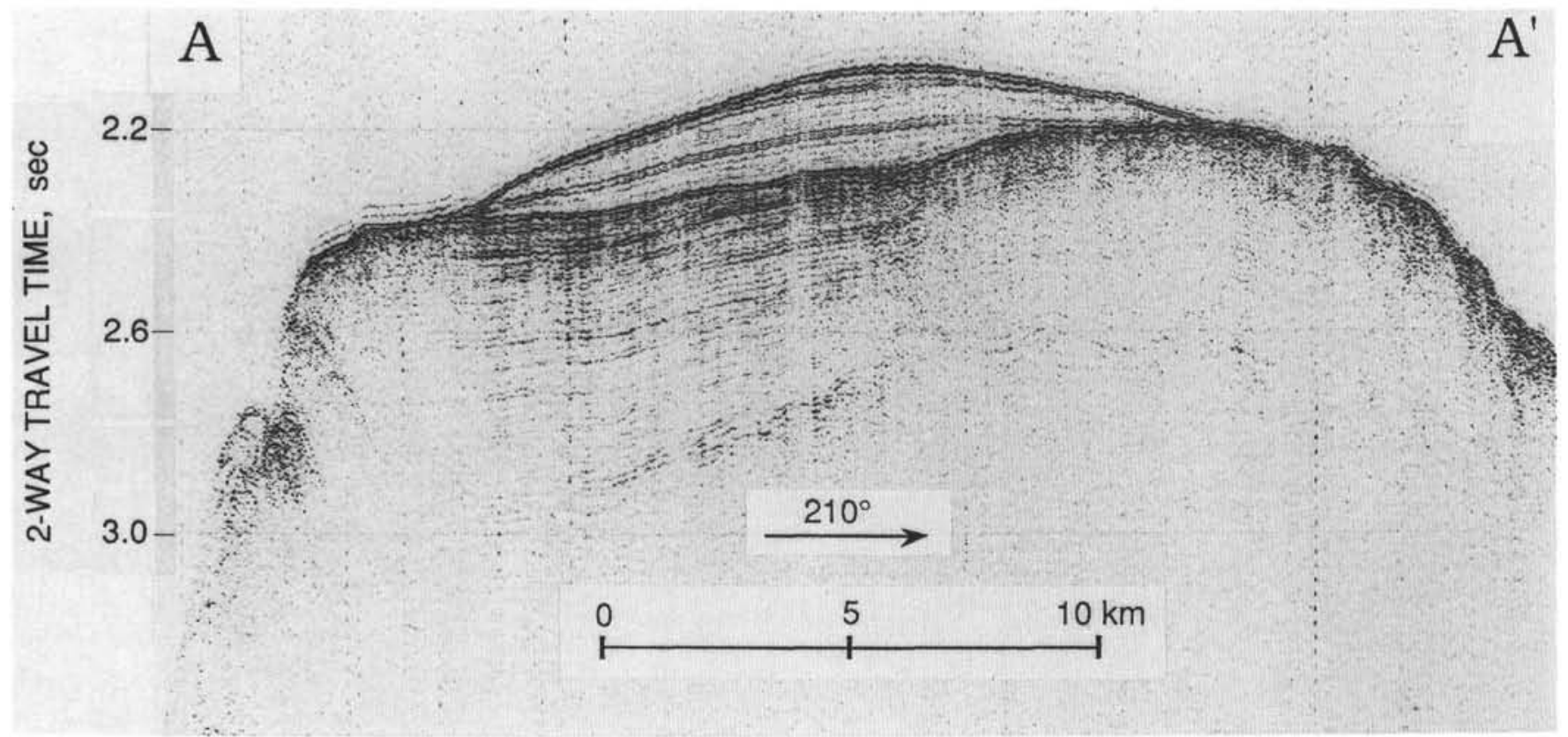

Figure 5. Reflection profile (A-A' in Fig. 3) across the east-central part of Allison Guyot. The unconformity between pelagic sediments and Albian platform limestone strata is the prominent reflector at about $2.37 \mathrm{~s}$ TWT on the left (north) side of the guyot. The profile shows arching of reflectors in the Lower Cretaceous platform limestone over the buried ridge and the right (south) side of the guyot. Note the truncation of reflectors in the platform limestone at the unconformity, and the onlap of pelagic sediments onto the arch. The thinning of the limestone section towards the arch is partly by onlap of lower reflectors onto the deepest strong reflector, at $2.6 \mathrm{~s}$ TWT at the crest of the arch. This reflector is correlated with the top of basalt near Site 865 (Shipboard Scientific Party, $1993 \mathrm{a}$ ). The prominent reflector within the pelagic sequence can be traced to Site 865 , where it correlates closely with the top of the Paleocene. Profile taken from Thomas Washington during SIO cruise Roundabout, Leg 10. Vertical exaggeration at seafloor about 13×.

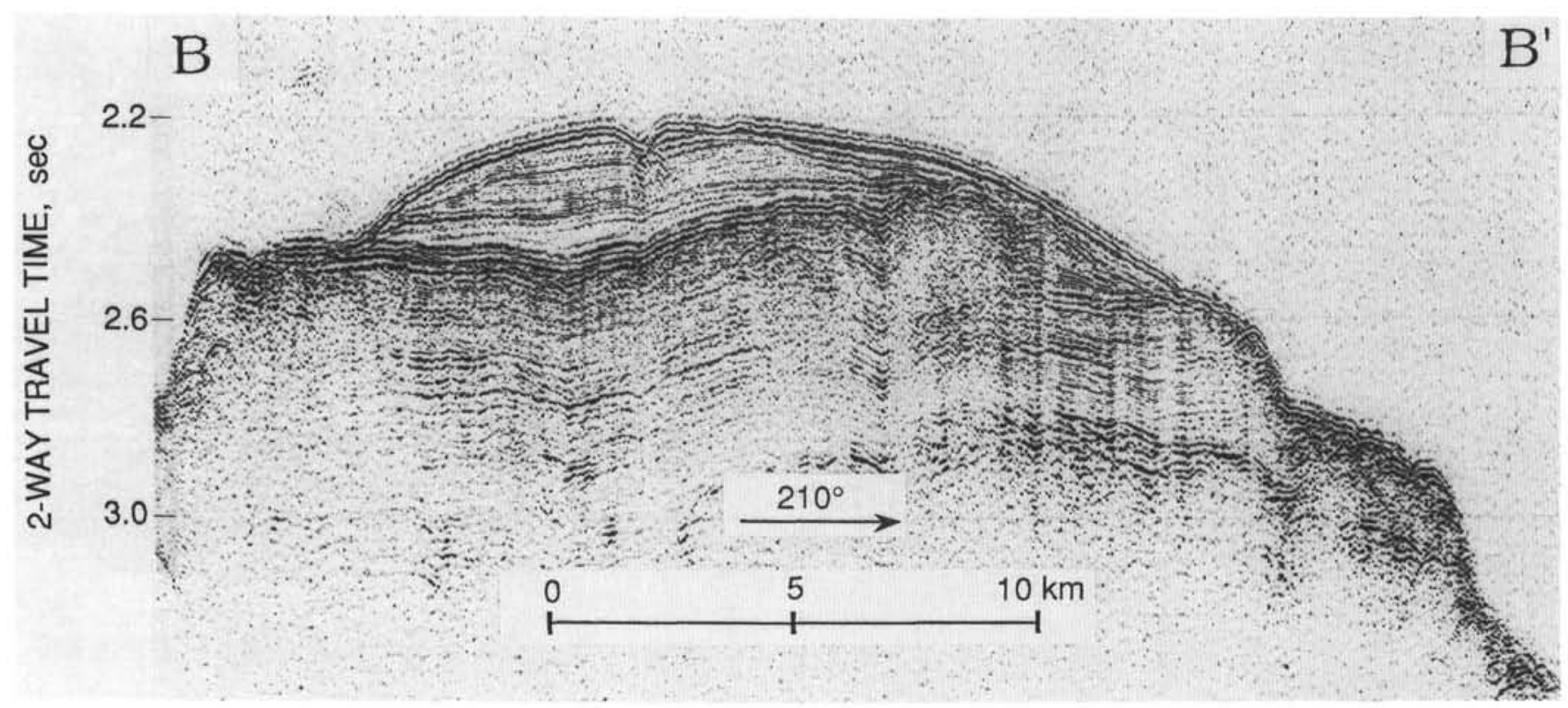

Figure 6. Reflection profile (B-B' in Fig. 3) across the eastern part of Allison Guyot. The unconformity between pelagic sediments and platform limestone strata is at about $2.45 \mathrm{~s}$ TWT on the left (north) side of the guyot. The southern (right) margin of the guyot shows a set of large slump scars truncating Lower Cretaceous platform limestone layers on the south side of an anticlinal arch. The upper scar, above about $2.55 \mathrm{~s}$ TWT, is buried by younger pelagic sediments. An unconformity at a high stratigraphic level within the pelagic sediments, marked by a truncating reflector that dips southwestward from near the shallowest point on the profile, suggests that the slump occurred during the late Cenozoic. Basaltic basement is inferred at the reflector at about $2.8 \mathrm{~s}$ TWT, on the crest of the anticlinal arch. Profile taken from Thomas Washington during SIO cruise Roundabout, Leg 10. Vertical exaggeration at seafloor about 13×. 


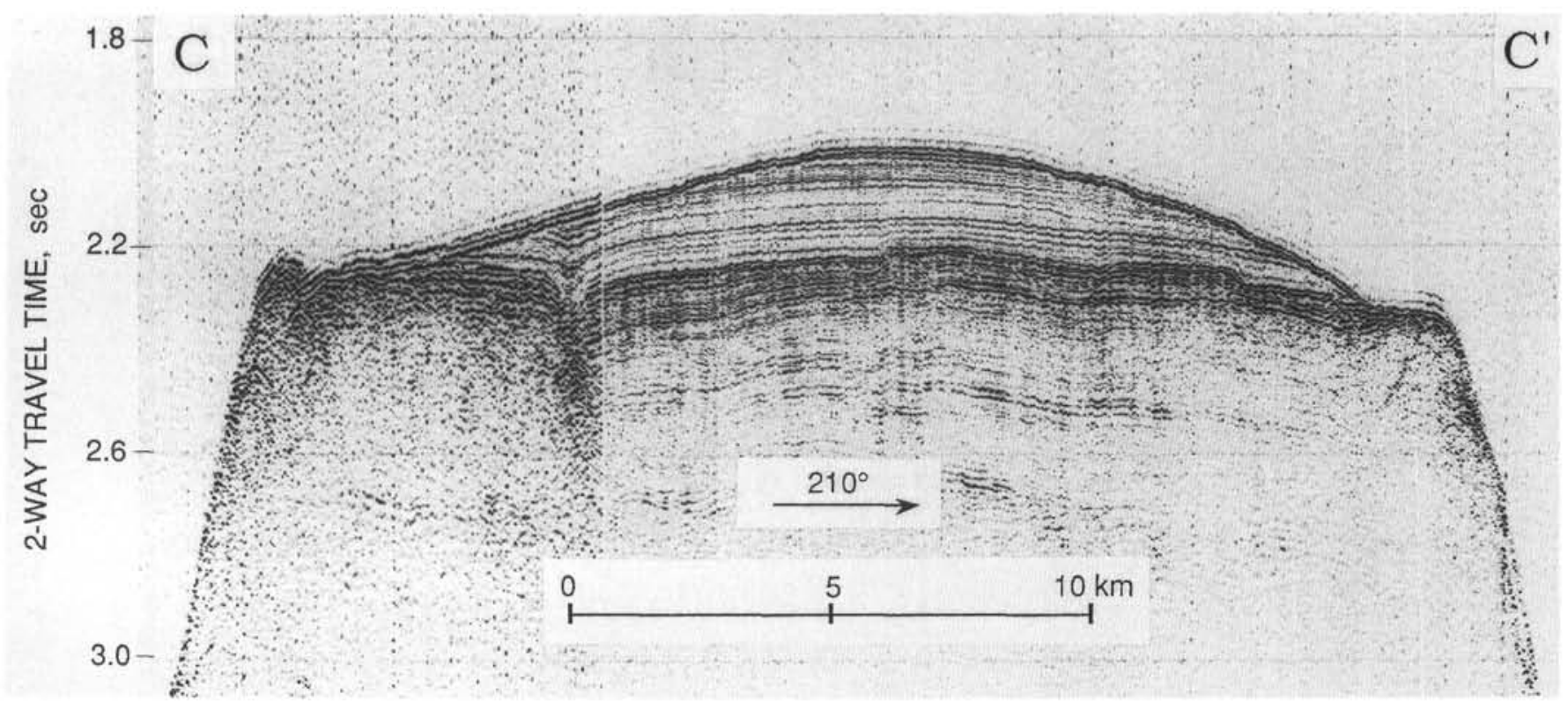

Figure 7. Reflection profile (C-C' in Fig. 3) across the west-central part of Allison Guyot, showing truncation of reflectors in the Lower Cretaceous platform limestone by the unconformity between the limestone and the overlying pelagic sediments. The unconformity is marked by the strong reflector at about $2.2 \mathrm{~s}$ TWT, under the summit of the guyot. The stepped topography on the unconformity is interpreted as the result of differential erosion of limestone layers. Profile taken from Thomas Washington during SIO cruise Roundabout, Leg 10. Vertical exaggeration at seafloor about $13 \times$.

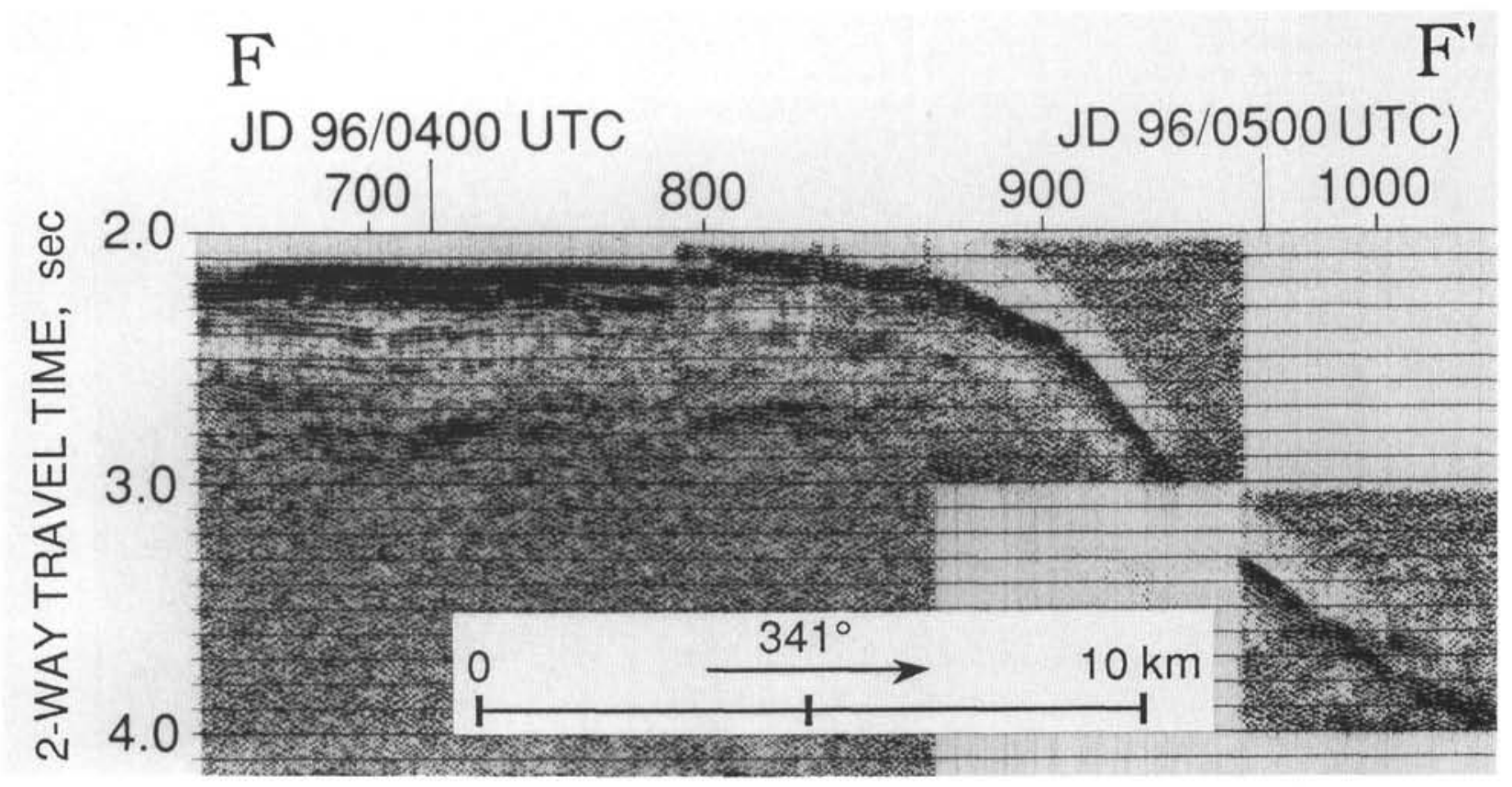

Figure 8. Processed ( $0.2 \mathrm{~s} \mathrm{AGC}$, mixed) seismic-reflection profile across the north end of Allison Guyot (F-F' in Fig. 3), showing smooth continuation of reflectors from the platform interior across the margin. The offset of the seafloor at Shotpoint 800 is an artifact. Profile taken from JOIDES Resolution during Leg 143 . Vertical exaggeration at seafloor about $5 \times$.

and mounds. As shown in a seismic-reflection profile (Fig. 11A) and on the accompanying depth section (Fig. 11B), most of the compaction is in the lower part of the platform sediments, in the part shown by drilling at Site 865 to include significant proportions of clayey limestone and mudstone interbedded with limestone (Shipboard Scientific Party, 1993a). The profile also shows the onlap of sediments against the volcanic basement hill. Drilling at Site 865 terminated in mixed volcanic sills and interbedded muddy sediments and limestone at about the level of the prominent reflector shown at 2.90 s two-way traveltime (TWT) (Fig. 11A) and both this profile and the profile at a right angle (Fig. 7) show that additional sediments occur beneath the deepest level drilled. As shown by the progressively greater bending of seismic reflectors with depth (Fig. 11), compaction of sediments began immediately as they were buried, and progressed as more and 
D

D'

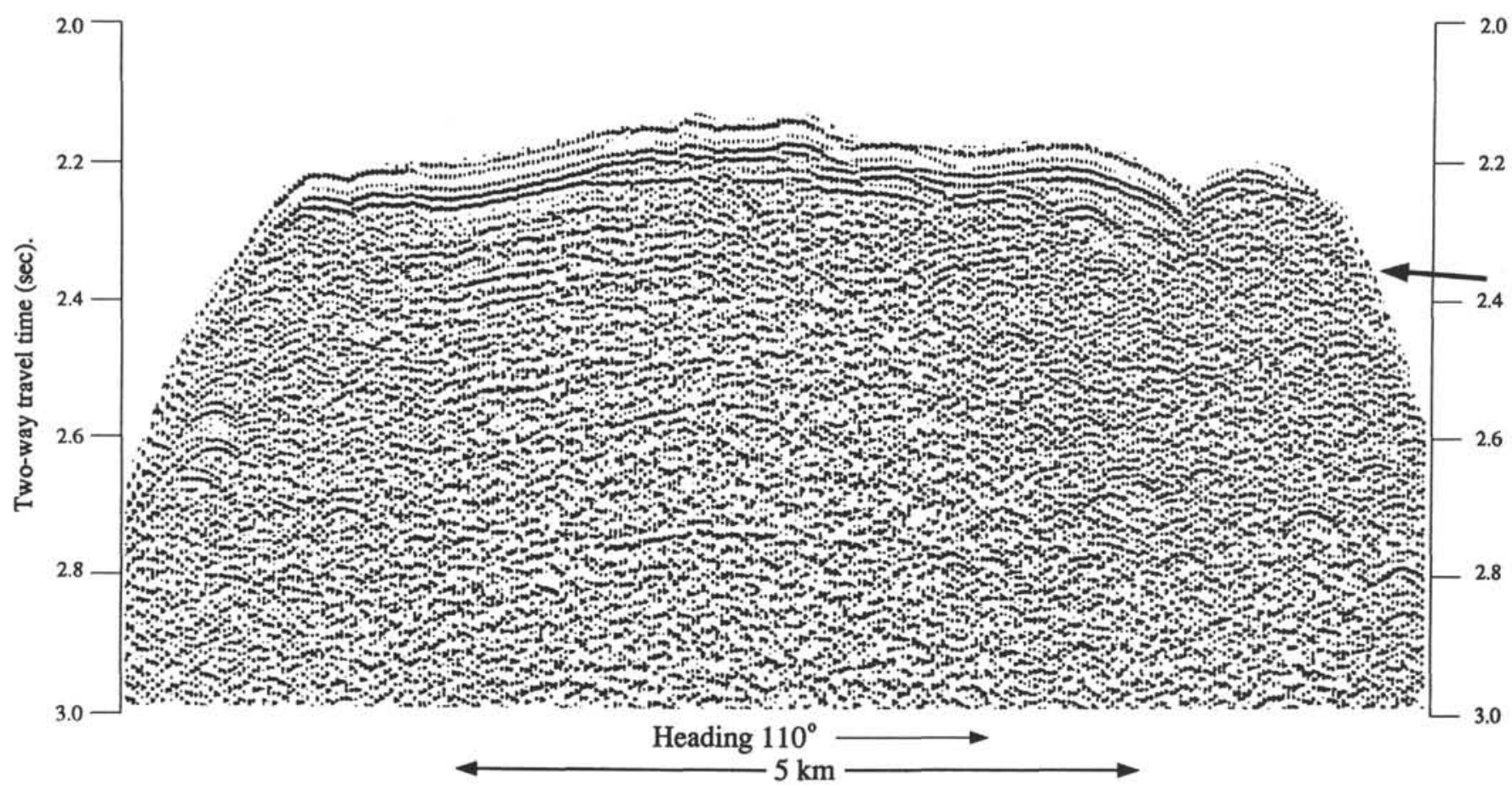

Figure 9. Processed ( $0.05 \mathrm{~s}$ AGC, filtered) seismic-reflection profile across north end of Allison Guyot (D-D' in Fig. 3), showing gently seaward-dipping reflectors in platform limestone beneath perimeter ridge at the east (right) end of the profile. The arrow on the right side of the figure is aligned with a prominent reflector. Upper reflectors are truncated at the moat behind the ridge, showing that the moat and ridge are the result of erosion, not of constructional processes. Profile taken from Thomas Washington during SIO cruise Roundabout, Leg 10. Vertical exaggeration at seafloor about $7 \times$.

more sediments were added. When the last volcanic relief was buried, clay deposition virtually ceased, and only limy sediments were deposited across the whole of the carbonate platform.

At any one time during accumulation of the platform limestone sequence, the top surface was essentially flat, at sea level. Thus, the present-day configuration of each of the limestone reflectors in Figure $11 \mathrm{~B}$ is a result of compaction from a formerly level surface. Using this criterion, the minimum total compaction of the deepest limestone interval, between volcanic basement and the volcanic sills, is about $50 \%$; from the sills to reflector $\mathrm{K} 5$, about $33 \%$, and from reflector $\mathrm{K} 5$ to the top of the limestone, about $21 \%$. These figures are compatible with the data from artificial-compaction experiments on modern carbonate sediments (Shinn and Robbin, 1983), keeping in mind that their experiments produced only mechanical compaction, whereas in nature, chemical compaction can be important as well and can continue long after the initial loading has ceased. The porosity of the Albian limestones is mainly between $10 \%$ and $20 \%$ (Shipboard Scientific Party, 1993a) and, assuming the system to be closed, the total predicted compaction would be about $75 \%$. The actual total compaction may thus be greater than the amount recorded simply by the differential warping of layers in the succession that lap out against basement. Compaction reduces the thickness of the limestone, and thus the water depth to the top of the Albian limestone increases over time, both from compaction and from thermal subsidence of the underlying lithosphere.

At the time of cessation of platform limestone deposition, close to the end of the Albian, the surface of the platform was nearly flat, at sea level. To produce the erosional landscape, that is, the drainage pattern, mesas, and closed depressions, the platform had to become emergent. For the drainage to have its actual pattern (Fig. 4), consistently running from the ridge areas downward toward the large depression on the eastern part of the guyot, and from the ridges toward the exterior of the guyot, implies that the originally flat surface became warped to form the low ridges. This, in turn, implies that differential compaction continued during the emergent stage.

The fact that seismic reflectors are obscured within the higher parts of the southern arch (Fig. 5) suggests modification, such as by diagenesis by meteoric waters, during emergence of the platform, after cessation of shallow-water limestone deposition in the latest Albian and before the time of deposition of the oldest pelagic sediments in cavities in the upper part of the limestone during Turonian time (Shipboard Scientific Party, 1993a). Following drowning, compaction continued, but at a slower and slower rate. The differential compaction was completed mainly prior to Cenozoic time, because Paleocene sediments onlap the arches (Fig. 5).

At some time following arching, a large slump, or set of slumps, developed along the south flank of the southern anticline, cutting deeply into and across the Lower Cretaceous limestone strata. Multibeam bathymetric data show that the fill in the submarine valley south of the guyot (Fig. 3) has a very hummocky topography, suggesting debris flows that originated from the slumps. According to the seismic reflection stratigraphy inferred from drilling at Site 865 (Shipboard Scientific Party, 1993a), the prominent unconformity visible within the overlying pelagic sediments (Fig. 6) suggests that the slumping happened during the Cenozoic.

\section{Petrography and Geochemistry of Core Samples from Upper Parts of Limestone}

The uppermost portion of the shallow-water carbonate section drilled on Allison Guyot (see Figs. 1A and 3 for location) consists of a thin (a few decimeters) crust of mineralized pelagic limestone associated with manganese oxide deposits (Site 865, Subunit IIA). This crust overlies a section of shallow-water limestone (Subunit IIB) that contains intervals with abundant cavities and fractures that are commonly filled with ce- 


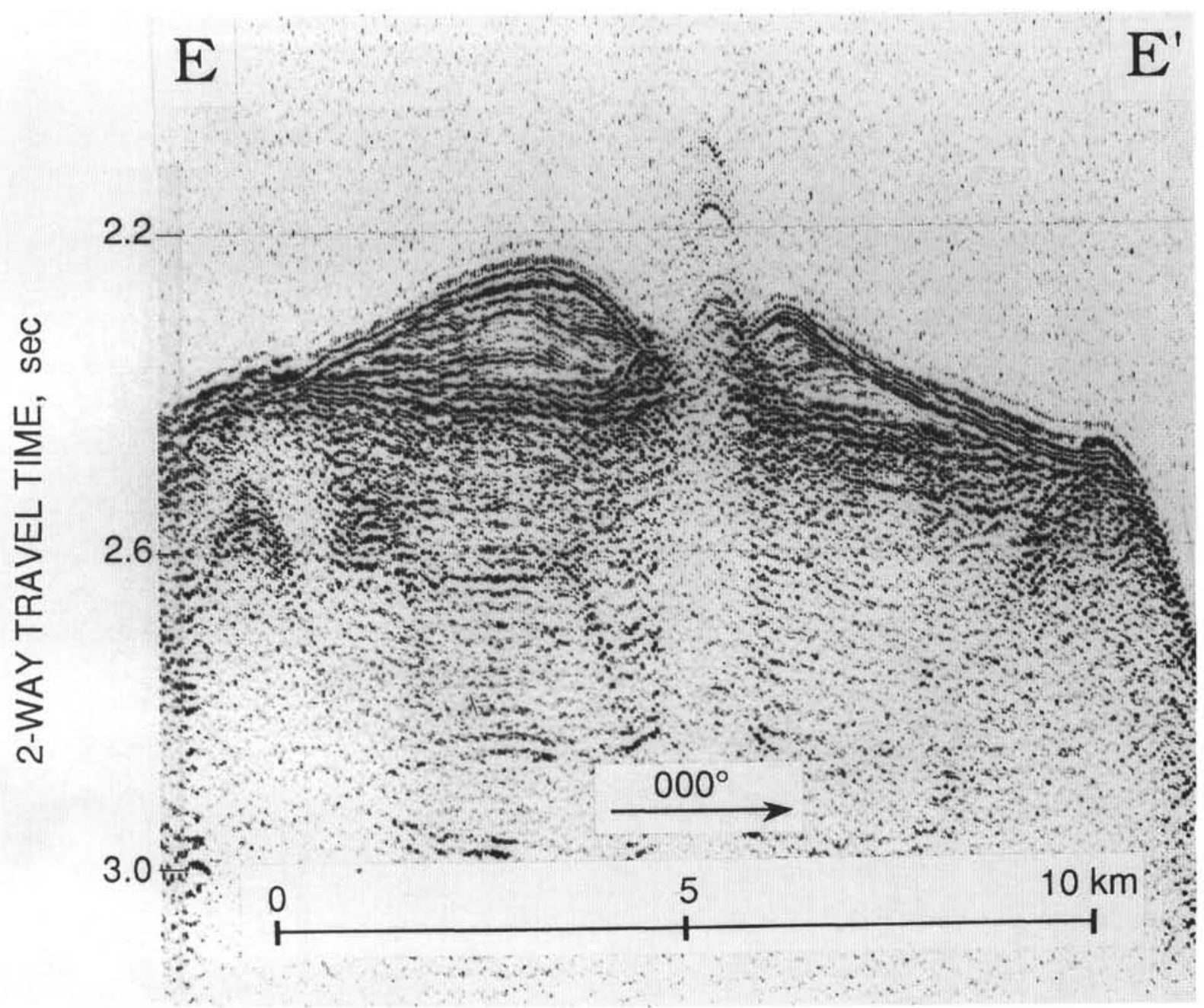

Figure 10. Reflection profile (E-E' in Fig. 3) showing an erosional moat around a volcanic cone. The cone was emplaced at about 85 Ma (Duncan and Pringle, this volume). Profile taken from Thomas Washington during SIO cruise Roundabout, Leg 10. Vertical exaggeration at seafloor about $13 \times$.

ments, internal sediments, and mineralized pelagic sediments (Shipboard Scientific Party, 1993a). The limestone facies comprise peloidal mudstone, wackestone, and packstone in which molds of mollusk shell debris are common. Several of the intervals of limestone with large fractures or cavities were subsampled and studied petrographically to establish the sequence of diagenetic events that led to their fractured and/or cemented states. Selected components from within these samples were analyzed for their stable isotopic composition (Tables 1-3).

Examples of intervals with centimeter-size, cement- and sedimentfilled cavities can be seen in Samples 143-865A-18R-CC, 0-2 cm (Fig. 12), 143-865A-22R-CC, 3-4 cm (Fig. 13), and 143-865B-17X-CC, 25-28 cm (Fig. 14). These samples show textural evidence of having similar diagenetic histories. Sample 143-865A-18R-CC, 0-2 cm (Fig. 12), consists of chalky, fossiliferous wackestone across which extends a planar, interrupted cavity, partly filled with white, tan, and dark brown laminated geopetal sediment. In cross section, the edge of the cavity forms a sharp boundary truncating grains in the host rock, indicating that the cavity walls are erosional, not some form of shelter porosity. Filling the cavity are several types of material: the earliest is a layer of clear, bladed, spar cement that lines cavity walls (Fig. 13) as well as open molds and, in a few places, completely fills smaller molds in the host rock. Overlying this cement are successive laminae of finely crystalline phosphatic silt. Infiltration and deposition of this sediment occurred episodically, resulting in distinct laminae that vary from dark brown (earliest) to white (latest). The latest deposits are either not or only slightly phosphatized. Small, secondary (moldic) pores elsewhere in the sample commonly are lined with bladed spar cement, but for the most part, contain no internal phosphatic sediment.

A typical example of the development and filling of moldic porosity is seen in Sample 143-865A-22R-CC, 3-4 cm (Fig. 14). It consists of chalky, fossiliferous wackestone containing a large $(3 \mathrm{~cm})$ mold of a gastropod shell, which has been completely dissolved and subsequently filled with several generations of cements and internal sediments. Surrounding the shell, and filling the whorls of the shell, is well-indurated, fossiliferous lime mud in which the shell was originally deposited. Parts of the shell that were not filled with mud developed a thin fringe of equant spar cement, possibly accompanying lithification of the mud. The original shell dissolved after lithification of the mud, leaving behind only micrite-filled borings of endolithic algae and fungi. A single generation of bladed calcite cement formed in this mold, followed by partial filling of the remaining spaces in the mold by fine, gray, crystal silt. This silt consists of tiny $(8-20 \mu \mathrm{m})$ euhedral calcite crystals. Overlying this silt, as well as covering the remaining cavity walls, is a second generation of bladed spar cement. This was followed by coating or infilling of the remaining mold-space with isopachous laminae of brown, phosphatic mud with no apparent microfossils (Fig. 15). This mud does not form geopetal deposits, but rather coats the cavity walls in layers of even thickness.

Sample 143-865B-17X-CC, 25-28 cm (Fig. 16), is a packstone of miliolid foraminifers and sponge spicules in a dense micrite matrix. 
Table 1. Stable isotopic analyses of samples from Site 865 .

\begin{tabular}{|c|c|c|c|c|}
\hline $\begin{array}{l}\text { Core, section, } \\
\text { interval }(\mathrm{cm})\end{array}$ & $\begin{array}{l}\delta^{13} \mathrm{C} \\
(\%) \text { ) }\end{array}$ & $\begin{array}{l}\delta^{18} \mathrm{O} \\
(\%))\end{array}$ & Sample description & $\begin{array}{c}\text { Meters } \\
\text { below top } \\
\text { of Albian } \\
\text { limestone }\end{array}$ \\
\hline \multicolumn{5}{|l|}{$143-865 \mathrm{~A}-$} \\
\hline 18R-CC, $0-2$ & 2.934 & -0.882 & Bulk host (matrix) & 5.02 \\
\hline $18 \mathrm{R}-\mathrm{CC}, 0-2$ & 1.703 & -2.072 & Laminated internal sediment (white) & 5.02 \\
\hline $18 \mathrm{R}-\mathrm{CC}, 0-2$ & 3.142 & -1.335 & Spar cement in mold & 5.02 \\
\hline $22 \mathrm{R}-\mathrm{CC}, 3-4$ & 2.783 & -1.042 & White micrite (host) & 38.70 \\
\hline $22 \mathrm{R}-\mathrm{CC}, 3-4$ & 2.695 & -1.642 & Micrite filling shell (matrix) & 38.70 \\
\hline $23 \mathrm{R}-\mathrm{CC}, 15-16$ & 3.103 & -2.136 & Bulk host sample (matrix) & 48.50 \\
\hline $28 \mathrm{R}-1,0-1$ & 2.603 & -1.543 & Bulk host sample (matrix) & 96.60 \\
\hline $28 \mathrm{R}-1,0-1$ & 1.383 & -4.520 & Brown shell material & 96.60 \\
\hline $28 \mathrm{R}-1,0-1$ & 2.902 & -1.034 & Yellow-stained spar cement in cavity & 96.60 \\
\hline $34 \mathrm{R}-1,1-2$ & 1.989 & -2.041 & Bulk host sample (matrix) & 154.50 \\
\hline $34 \mathrm{R}-1,1-2$ & 2.290 & -0.513 & White internal sediment & 154.50 \\
\hline $34 \mathrm{R}-1,1-2$ & 2.993 & -1.624 & Spar cement in fracture & 154.50 \\
\hline 36R-CC, $17-18$ & 2.204 & -2.235 & Bulk host sample (matrix) & 173.60 \\
\hline $37 \mathrm{R}-\mathrm{CC}, 11-12$ & 1.460 & -1.704 & Bulk host sample (matrix) & 183.20 \\
\hline 37R-CC, $11-12$ & 2.127 & -1.882 & Gray sediment in burrow (matrix) & 183.20 \\
\hline 40R-CC, $0-1$ & 3.119 & -2.083 & Pebble of host wackestone & 211.80 \\
\hline \multicolumn{5}{|l|}{ 143-865B- } \\
\hline $17 \mathrm{X}-\mathrm{CC}, 25-28$ & 2.351 & -2.202 & Fragment of host wackestone & 2.30 \\
\hline $17 \mathrm{X}-\mathrm{CC}, 25-28$ & 2.554 & -2.509 & Sandy internal sediment between breccia clasts & 2.30 \\
\hline $17 \mathrm{X}-\mathrm{CC}, 25-28$ & 2.683 & -2.617 & White pelagic internal sediment & 2.30 \\
\hline $17 \mathrm{X}-\mathrm{CC}, 25-28$ & 1.581 & -2.479 & White pelagic internal sediment & 2.30 \\
\hline $17 \mathrm{X}-\mathrm{CC}, 28-30$ & 2.052 & -1.894 & Fragment of host wackestone & 2.35 \\
\hline $17 \mathrm{X}-\mathrm{CC}, 28-30$ & 2.639 & -2.459 & Muddy internal sediment between breccia clasts & 2.35 \\
\hline $17 \mathrm{X}-\mathrm{CC}, 28-30$ & 1.510 & -2.403 & Phosphatic internal sediments & 2.35 \\
\hline $18 \mathrm{X}-\mathrm{CC}, 1-2$ & 2.668 & -1.119 & Bulk host mudstone (matrix) & 6.50 \\
\hline $18 \mathrm{X}-\mathrm{CC}, 1-2$ & 2.907 & -1.688 & Crystal silt internal sediment & 6.50 \\
\hline $18 \mathrm{X}-\mathrm{CC}, 1-2$ & 2.537 & -1.169 & Coarse spar cement & 6.50 \\
\hline $18 \mathrm{X}-\mathrm{CC}, 1-2$ & 2.642 & -1.476 & Sandy internal sediment & 6.65 \\
\hline $18 \mathrm{X}-\mathrm{CC}, 1-2$ & 1.513 & -1.910 & Phosphatic internal sediment & 6.50 \\
\hline
\end{tabular}

Table 2. Stable isotopic analyses of samples from Site $\mathbf{8 6 6 .}$

\begin{tabular}{|c|c|c|c|c|}
\hline $\begin{array}{l}\text { Core, section, } \\
\text { interval }(\mathrm{cm})\end{array}$ & $\begin{array}{l}\delta^{13} \mathrm{C} \\
(\% \circ)\end{array}$ & $\begin{array}{l}\delta^{18} \mathrm{O} \\
(\%(\%)\end{array}$ & Sample description & $\begin{array}{l}\text { Depth } \\
\text { (mbsf) }\end{array}$ \\
\hline 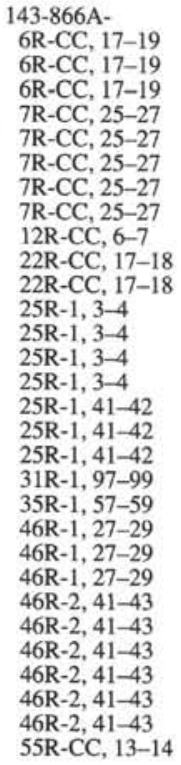 & $\begin{array}{l}2.672 \\
2.836 \\
2.805 \\
2.675 \\
2.609 \\
2.956 \\
2.823 \\
2.952 \\
2.643 \\
2.821 \\
2.609 \\
2.072 \\
2.053 \\
2.349 \\
2.380 \\
2.596 \\
2.757 \\
2.502 \\
2.225 \\
3.151 \\
2.882 \\
2.850 \\
2.404 \\
1.935 \\
2.751 \\
2.208 \\
2.469 \\
2.463 \\
2.378 \\
1.256\end{array}$ & $\begin{array}{r}-2.112 \\
-2.312 \\
-1.472 \\
-2.038 \\
-1.959 \\
-2.084 \\
-1.318 \\
-0.984 \\
-2.169 \\
-1.589 \\
-3.013 \\
-3.012 \\
-2.710 \\
-2.712 \\
-2.627 \\
-2.358 \\
-3.031 \\
-2.562 \\
-2.750 \\
-1.340 \\
-3.856 \\
-2.353 \\
-3.129 \\
-4.944 \\
-5.541 \\
-2.069 \\
-1.962 \\
-1.938 \\
1.579 \\
-5.684\end{array}$ & $\begin{array}{l}\text { Mollusk shell fragment } \\
\text { Bulk host sample (matrix) } \\
\text { Spar in mold (with reddish stain) } \\
\text { Bulk host sample (matrix) } \\
\text { Mollusk shell fragment (preserved) } \\
\text { Internal sediment in small cavity } \\
\text { Spar above internal sediment in cavity } \\
\text { Spar cement in larger fissure } \\
\text { Bulk host sample (matrix) } \\
\text { Micritic blue-green algae fragment } \\
\text { Bulk host (matrix between large grains) } \\
\text { Bulk host sample (matrix) } \\
\text { Coarse spar in crack } \\
\text { Internal sediment in crack } \\
\text { Late-stage alteration of edge of rock } \\
\text { Bulk host sample (matrix) } \\
\text { Gray micrite band } \\
\text { Gray micrite band } \\
\text { Bulk host sample (matrix) } \\
\text { Bulk host sample (matrix) } \\
\text { Bulk host sample (matrix) } \\
\text { Coarse spar in mold } \\
\text { Fine spar from inside open "tunnel" } \\
\text { Bulk host sample (matrix) } \\
\text { White micrite in cavity } \\
\text { Cemented white rubbly fill } \\
\text { White micrite fill in smaller cavity } \\
\text { Cemented white rubbly layer } \\
\text { Late-stage dog-tooth spar in small cavity } \\
\text { Bulk host sample (matrix) }\end{array}$ & $\begin{array}{r}38.58 \\
38.58 \\
38.58 \\
48.08 \\
48.08 \\
48.08 \\
48.08 \\
48.08 \\
96.18 \\
193.98 \\
193.98 \\
222.68 \\
222.68 \\
222.68 \\
222.68 \\
222.68 \\
222.68 \\
222.68 \\
281.48 \\
319.48 \\
415.58 \\
414.58 \\
415.58 \\
417.18 \\
417.18 \\
417.18 \\
417.18 \\
417.18 \\
417.18 \\
50.98\end{array}$ \\
\hline $\begin{array}{l}143-866 \mathrm{~B}- \\
5 \mathrm{M}-1,17-19 \\
6 \mathrm{M}-1,41-43 \\
7 \mathrm{M}-1,54-57 \\
7 \mathrm{M}-1,54-57 \\
7 \mathrm{M}-1,54-57 \\
7 \mathrm{M}-1,54-57 \\
7 \mathrm{M}-1,54-57 \\
8 \mathrm{M}-1,53-54 \\
12 \mathrm{M}-1,37-39 \\
12 \mathrm{M}-1,37-39\end{array}$ & $\begin{array}{l}1.943 \\
2.520 \\
3.200 \\
2.200 \\
2.436 \\
1.912 \\
2.515 \\
1.999 \\
2.661 \\
2.521\end{array}$ & $\begin{array}{l}-3.275 \\
-2.397 \\
-4.129 \\
-4.006 \\
-2.799 \\
-4.481 \\
-3.107 \\
-3.724 \\
-3.380 \\
-5.160\end{array}$ & $\begin{array}{l}\text { Bulk host sample (micrite) } \\
\text { Bulk host sample (micrite) } \\
\text { Rudist shell fragment (preserved) } \\
\text { Homogeneous micrite in rudist chamber } \\
\text { Coarse spar in rudist shell } \\
\text { Yellowish-tan homogeneous micrite } \\
\text { Bulk host wackestone (matrix) } \\
\text { Bulk host wackestone (matrix) } \\
\text { Bulk host wackestone (matrix) } \\
\text { Brown shell material (original shell?) }\end{array}$ & $\begin{array}{l}32.98 \\
42.58 \\
52.28 \\
52.28 \\
52.28 \\
52.28 \\
52.28 \\
61.58 \\
98.88 \\
98.88\end{array}$ \\
\hline
\end{tabular}


A

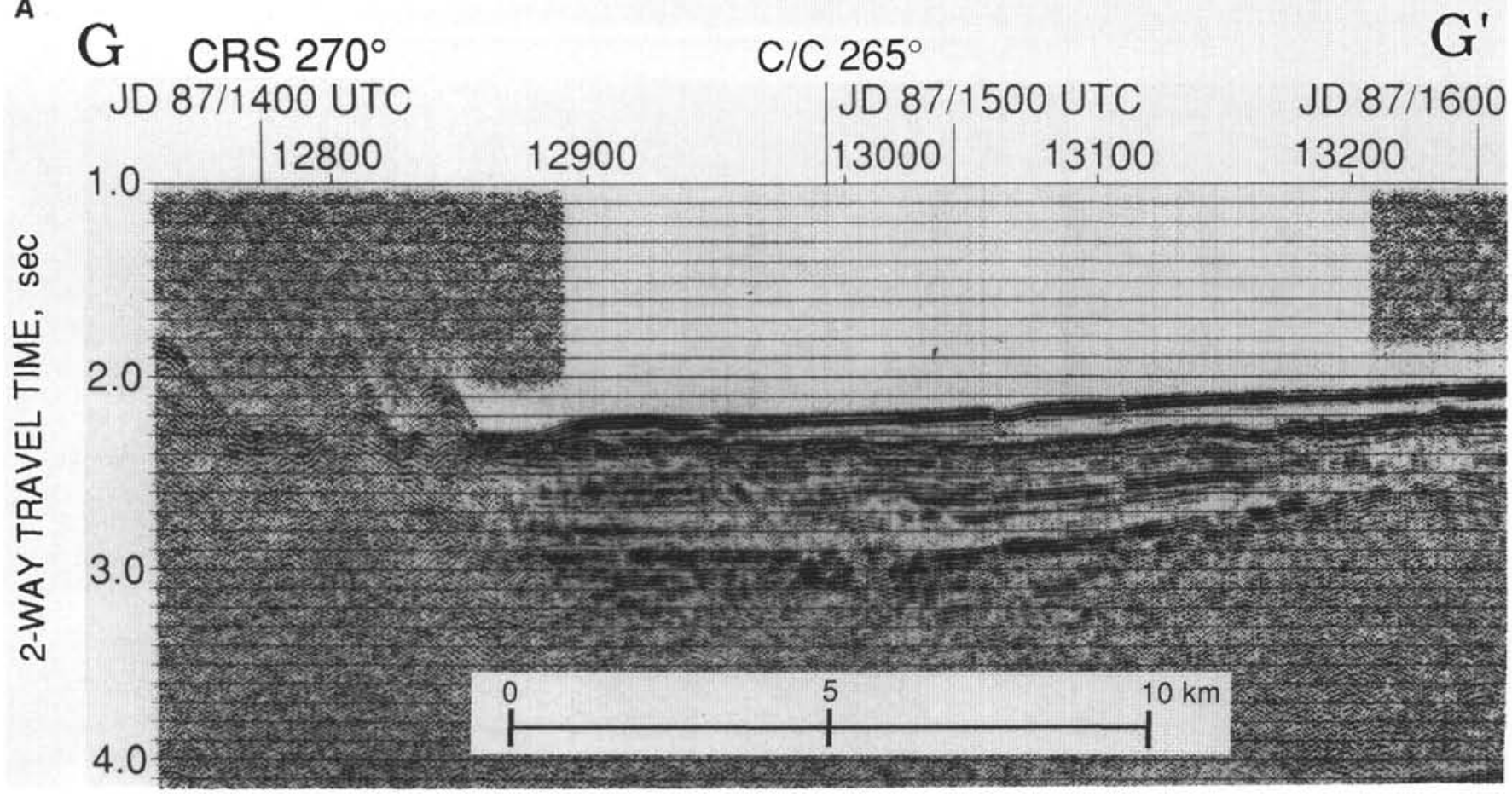

B

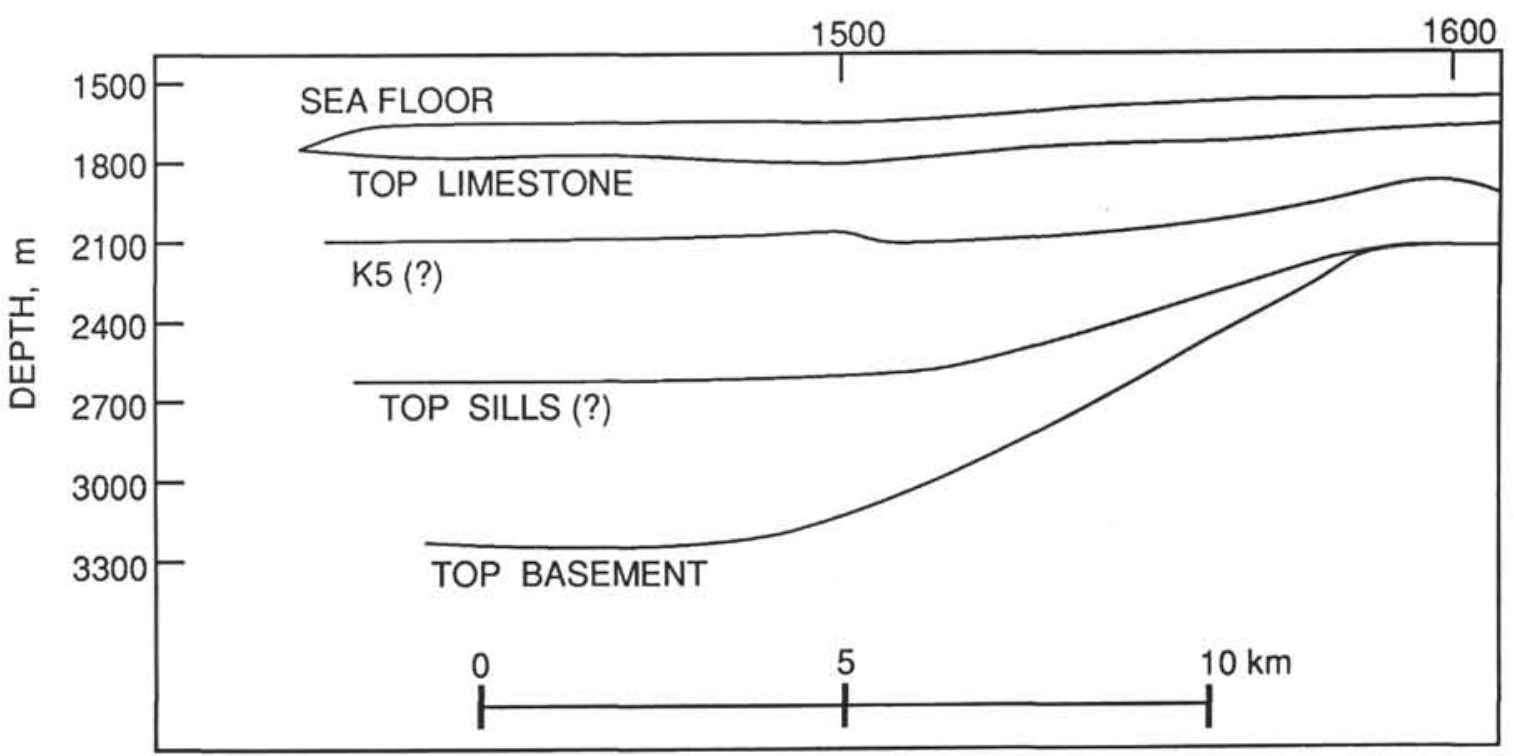

Figure 11. Profile across southeast part of Allison Guyot line (G-G' in Fig. 3). A. Processed ( $0.2 \mathrm{~s} \mathrm{AGC,} \mathrm{mixed)} \mathrm{seismic} \mathrm{line,} \mathrm{showing} \mathrm{buried} \mathrm{basement} \mathrm{topography.}$ The reflector at $2.90 \mathrm{~s}$ TWT is interpreted as corresponding to the sills drilled at Site 865 , and the prominent reflector at $2.55 \mathrm{~s}$ TWT is correlated with the prominent reflector labeled K5 at Site 865 (Shipboard Scientific Party, 1993a). The thick platform strata onlap the basement progressively to the west (right). Vertical exaggeration at seafloor about $4 \times$. B. Depth section along line of seismic profile, using velocity structure at Site 865 , extrapolated to basement (using $3.3 \mathrm{~km} / \mathrm{s}$ average velocity in limestones above basement).

The packstone has been broken into several centimeter-size angular pieces. Filling the space between the breccia clasts is well-sorted fine sand of pellets and small micritized skeletal fragments that are completely cemented with fine, equant calcite. Overlying this internal sediment in some places is gray, crystalline silt similar to that filling secondary pore space in Sample 143-865A-22R-CC, 3-4 cm (Fig. 14). Where the silt is absent, the sandy sediment is overlain by coarse, equant spar cement. The silt forms pseudogeopetal deposits that appear to floor open cavities, but with inconsistent attitudes. The silt infiltrates the underlying sandy sediment, indicating that cementation of the pelletoidal sand had not been completed at the time the silt was deposited. Following the silt is a single generation of equant spar cement that coats the silt deposits as well as other open surfaces not covered by silt. Most of the remaining secondary porosity is filled with very fine-grained, laminated, phosphatic mud that in many places forms laminae that follow the contours of the cavity they fill. The earliest laminae, directly overlying the crystal silt, contain abundant fragments of skeletal debris and small micritic clasts similar to 
Table 3. Stable isotopic analyses from interval 143-867B-4R-1, 123-130 cm.

\begin{tabular}{|c|c|c|}
\hline $\begin{array}{l}\delta^{13} \mathrm{C} \\
(\%)\end{array}$ & $\begin{array}{l}\delta^{18} \mathrm{O} \\
(\% c)\end{array}$ & Sample description \\
\hline \multicolumn{3}{|c|}{$\begin{array}{l}\text { Samples from a transect starting in } \\
\text { host, crossing into cavity-filling } \\
\text { deposits: }\end{array}$} \\
\hline 1.686 & -5.165 & Host grainstone \\
\hline 1.572 & -6.020 & Host grainstone \\
\hline 1.661 & -4.732 & Host grainstone \\
\hline 1.604 & -5.193 & Micrite at edge of cavity \\
\hline 1.218 & -5.053 & Micrite at edge of cavity \\
\hline 1.009 & -6.356 & Fine-grained detritus, near edge of cavity \\
\hline 0.651 & -5.879 & Fine-grained detritus, near edge of cavity \\
\hline 1.121 & -5.943 & Fine-grained detritus, near edge of cavity \\
\hline 2.241 & -8.392 & Earliest coarse spar \\
\hline 2.123 & -8.607 & Coarse spar \\
\hline 2.403 & -4.096 & Latest-stage dog-toothed spar \\
\hline \multicolumn{3}{|c|}{$\begin{array}{l}\text { Samples of one of the small } \\
\text { "stalagmites": }\end{array}$} \\
\hline 1.450 & -6.198 & Micrite in alteration zone \\
\hline 0.565 & -6.369 & Micrite in alteration zone \\
\hline 2.602 & -3.043 & Crystal spar in alteration zone \\
\hline 1.613 & -4.651 & Crystal spar on cavity wall \\
\hline 0.189 & -6.461 & Micrite in alteration zone \\
\hline \multicolumn{3}{|c|}{$\begin{array}{l}\text { Samples from another small, } \\
\text { mostly occluded cavity found } \\
\text { above the main one: }\end{array}$} \\
\hline 0.281 & -6.207 & Micrite edge of cavity (alteration rim) \\
\hline 1.971 & -3.786 & Microspar in host grainstone (top of cavity fill) \\
\hline 2.282 & -2.544 & Fragile microspar cements near cavity roof \\
\hline
\end{tabular}

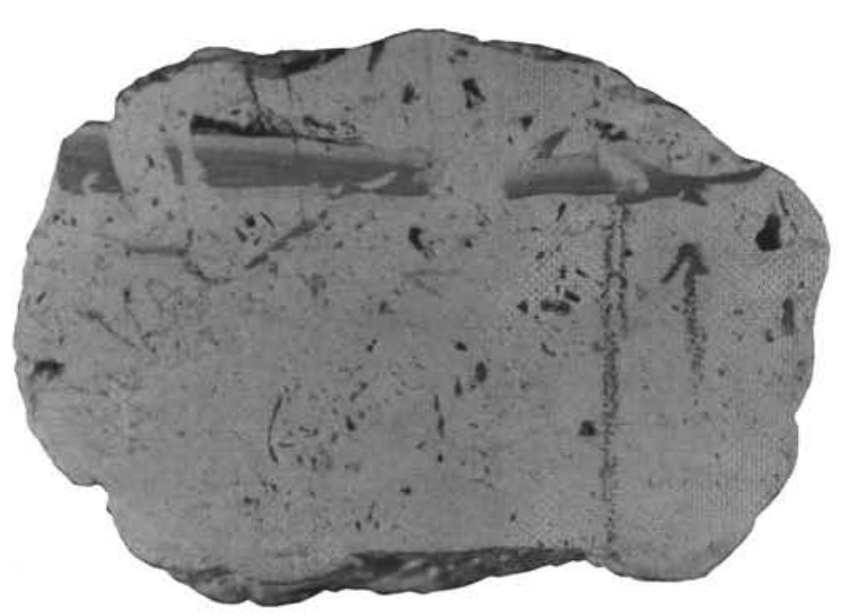

Figure 12. Close-up of core from Sample 143-865A-18R-CC, $0-4 \mathrm{~cm}$, showing white, chalky wackestone with abundant small-scale moldic porosity. A planar cavity partially filled with laminated, fine-grained, phosphatic sediment occupies the top part of the sample. The cavity is approximately $1 \mathrm{~cm}$ high, and interrupted by "pillars" of surrounding host sediment.

the host wackestone. Successively younger laminae of the phosphatic mud contain less shallow-water-derived material, whereas planktonic foraminifers become more and more abundant. The phosphatic deposits do not infiltrate the underlying silt or the pelletoidal sand. This suggests cementation of the earlier internal sediments was completed prior to deposition of the phosphatic mud.

Because the mud abuts wackestone breccia clasts as well as the crystal silt laminae with no apparent authigenic cements bordering these, it is possible that the silt occupies pore space developed after deposition and cementation of the previous generations of internal sediments.

Summarizing the petrographic observations, the formation of cavities in Unit II of Site 865 shows consistent elements of diagenesis in

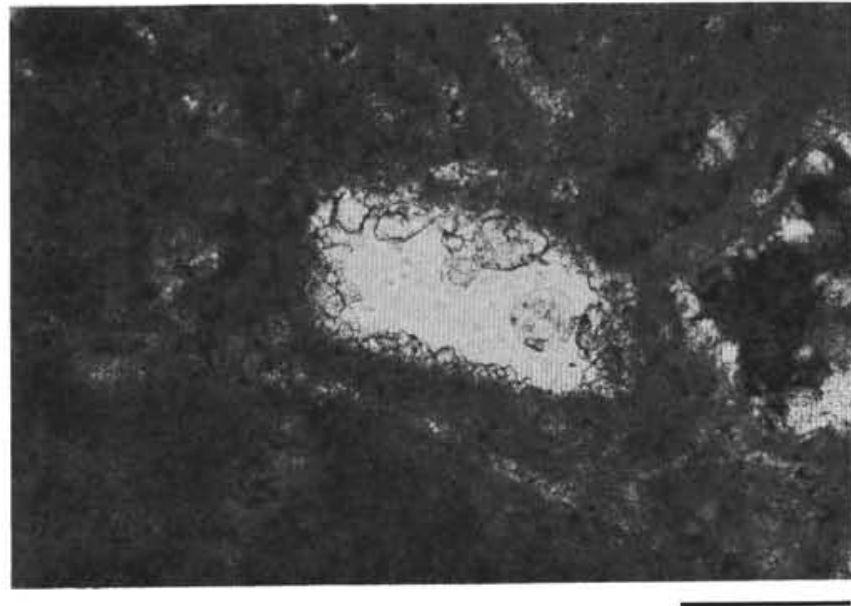

$0.3 \mathrm{~mm}$

Figure 13. Thin-section photomicrograph of Sample 143-865A-18R-CC, $0-4$ $\mathrm{cm}$, showing fine-grained wackestone texture (dark) with a mold of a small, rectangular, skeletal fragment. On the walls of the open mold, calcite cement forms bladed crystals. Surrounding the central mold are smaller molds that have been completely occluded with fine, crystalline calcite. Scale bar is $0.3 \mathrm{~mm}$.

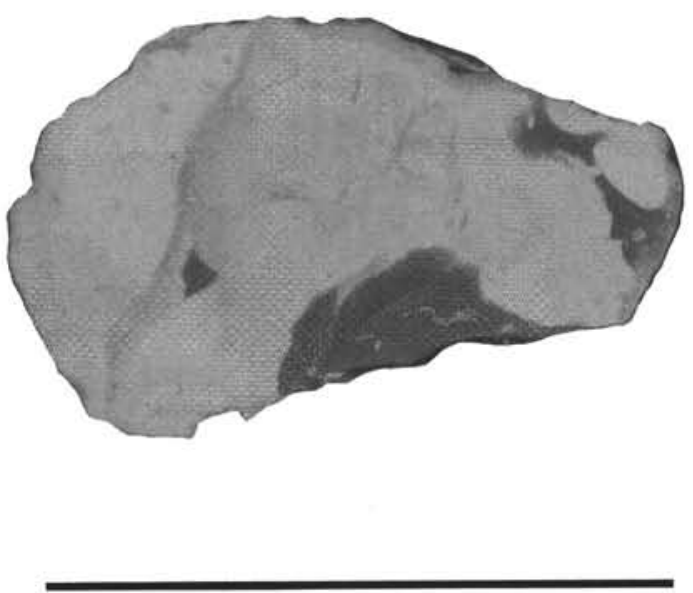

Figure 14. Close-up of core from Sample 143-865A-22R-CC, 3-4 cm, showing pelletal wackestone that fills the whorls of a large, thin-shelled gastropod shell (white and light gray). Thin, curved, darker bands show the micritized edges of the original shell walls. Part of the porosity created by the dissolution of these walls was filled with fine-grained phosphatic sediments that form isopachous and irregular laminae in the top and right parts of the specimen (dark). The black line on the scale is $3 \mathrm{~cm}$ in length.

several of the available samples. Secondary porosity formed in wackestone and packstone facies subsequent to initial lithification of the host material. This porosity took the form of planar cavities, irregular spaces between brecciated pebbles, and molds of large mollusk shells (mostly gastropods). This suggests both chemical removal and mechanical breakup of the original sediments. The secondary porosity was filled by successive generations of marine cement, crystalline internal sediment, pelletoidal sand, and, in some places, fossiliferous lime mud. All of these components appear to be of shallow-water origin, suggesting the creation of pore space and initial filling of this space occurred fairly early in the history of the deposits, before the guyot had sunk into the pelagic realm. 


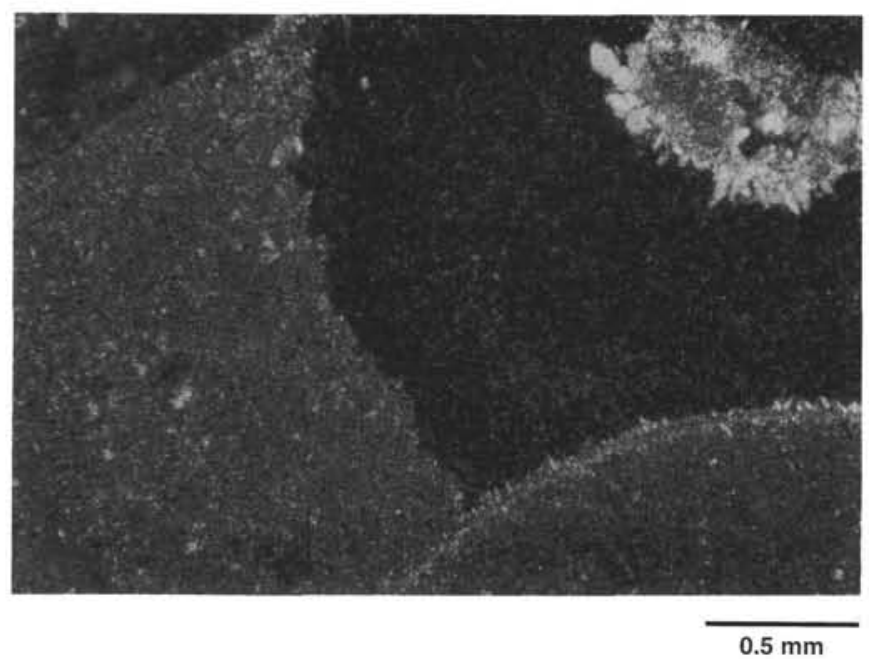

Figure 15. Thin-section photomicrograph of Sample 143-865A-22R-CC, 3-4 $\mathrm{cm}$, showing internal sediments that fill the space created by dissolution of a gastropod shell. The original shell wall is visible as a thin, micritic boundary (curved line) on which small, bladed, calcite crystals have formed. Part of the shell mold is filled with crystal silt (medium gray), which is overlain by very fine-grained, phosphatic sediment (dark). Bladed, spar cement also overlies the micritic edge of a small borehole that formed prior to dissolution of the shell wall, and is now completely surrounded by phosphatic sediment. Scale bar is $0.5 \mathrm{~mm}$.

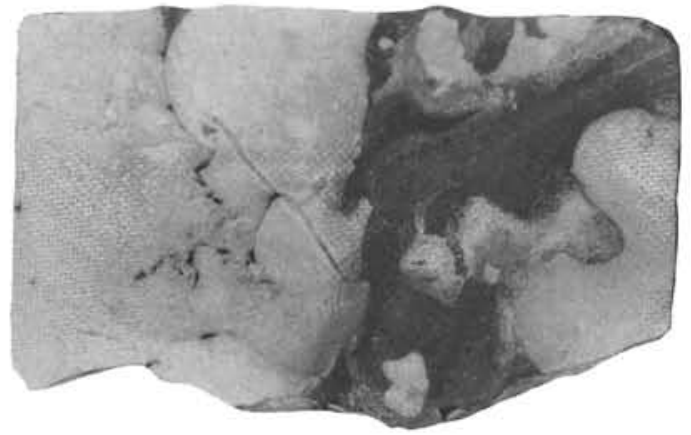

Figure 16. Close-up of core from Sample 143-865B-17X-CC, 25-28 cm, showing centimeter-to millimeter-sized clasts of packstone (white) surrounded by pelletal sand (light gray, specked with white, especially in lower half of sample). Also filling spaces between breccia clasts is very fine-grained, laminated phosphatic sediment (dark). The black line on the scale is $3 \mathrm{~cm}$ long.

Subsequent to these events, the remaining pore spaces were filled by a different type of internal sediment that was phosphatized to various degrees. This phosphatic internal sediment consists primarily of pelagic material (nannofossil ooze with foraminifers) mixed in varying degrees with shallow-water-derived components.

The greatest depth of penetration into the shallow-water platform by these pelagic sediments is about $20 \mathrm{~m}$ below the present-day top of the shallow-water section (Sample 143-865A-22-CC, 3-4 cm). This suggests that a system of interconnected cavities must have existed that allowed these sediments to percolate through the section after submergence of the guyot top to pelagic depths. The topography of the upper surface of the limestone near Site 865 (Fig. 4) suggests that several tens of meters of limestone originally lay above the present-day top of the limestone, but has been removed by erosion.

The origin for the cavity system remains unclear: removal of material (in some places, along bedding planes) has created the open porosity in what are otherwise fine-grained rocks. In many places, the host rocks became fragmented, resulting in breccia-like fabrics. In other places, simple dissolution of large aragonitic shells resulted in the production of porosity that was connected to other cavities. Possible mechanisms for these processes include dissolution of the host rock by percolating fluids undersaturated with respect to calcite, such as fresh water.

Another possibility is the removal of soluble minerals, such as evaporites, by circulation of marine or fresh waters. This could have occurred when the section was flushed with seawater, either shortly after drowning of the platform or during a slight rise of sea level during its growth. It could also occur as a result of exposure of the summit above sea level. No other evidence of possible evaporites in the upper part of the section is known from drilling at Allison Guyot.

The initial filling of the cavities with shallow-water carbonate sediments suggests that the porosity was formed either when the platform was still at or near sea level and shallow-water sediments were still being produced, or while such sediments were still unaffected by early cementation or other diagenetic processes and were free to move through the porous, lithified substrate. Below Subunit IIIA, no intervals bearing similar secondary porosity were observed, suggesting that the processes of cavity formation were limited to only the top $150 \mathrm{~m}$ of the shallow-water limestone section. Although abundant moldic porosity occurs below this depth, these molds are nowhere filled with internal sediment, and there is no evidence of interconnection of larger cavities.

\section{Stable Isotopic Analyses}

Samples from Site 865 (Allison Guyot) were analyzed for stable isotopic ratios of oxygen and carbon. The results (Table 1) are plotted in Figure 17, and are shown vs. depth below the top of the shallowwater platform. For oxygen, most of the samples yielded $\delta^{18} \mathrm{O}$ values between $-3 \%$ and $0 \%$, with no significant differences between samples from the top $100 \mathrm{~m}$ and those from deeper in the section. At any given depth, there is some suggestion that the spar cements yield higher (more positive) values of $\delta^{18} \mathrm{O}$ than the shell fragments or the host wackestone samples. This suggests that the cements were precipitated from cooler waters, as might be expected during subsidence of the guyot top from warm surface waters to deeper, cooler waters. These cooling trends are not as well-defined as those inferred from dredged samples from many western Pacific guyots (van Waasbergen, 1993). This may be attributable to the lower water/rock ratios in the drilled section as compared to samples that were collected from the outer slopes of the guyots.

Values of $\delta^{13} \mathrm{C}$ range between $+1.5 \%$ and $+3.5 \%$ (Table 1 ; Fig. 17). Once again, there is no apparent difference between values from the upper and lower parts of the section. The range of isotopic values falls well within that normally associated with calcite precipitated in normal seawater (Lohmann, 1988).

\section{Resolution Guyot}

\section{Morphology of Resolution Guyot Summit Area}

The generalized bathymetry of the summit region of Resolution Guyot (Fig. 18; Res in Fig. 1A), which was drilled at Sites 866, 867, and 868 during Leg 143 (Shipboard Scientific Party, 1993b, 1993c), shows a somewhat rectangular outline and a broadly domal summit about $25 \mathrm{~km}$ across at a water depth between about 1300 and $1400 \mathrm{~m}$. The high point is on the west-central part of the summit, but a small limestone peak in the east-central sector rises to $1280 \mathrm{~m}$. Several round, open depressions into the Lower Cretaceous limestone dot the central region, and one of these is about $80 \mathrm{~m}$ deep and $0.5 \mathrm{~km}$ wide. 
Site 865 (Allison Guyot)

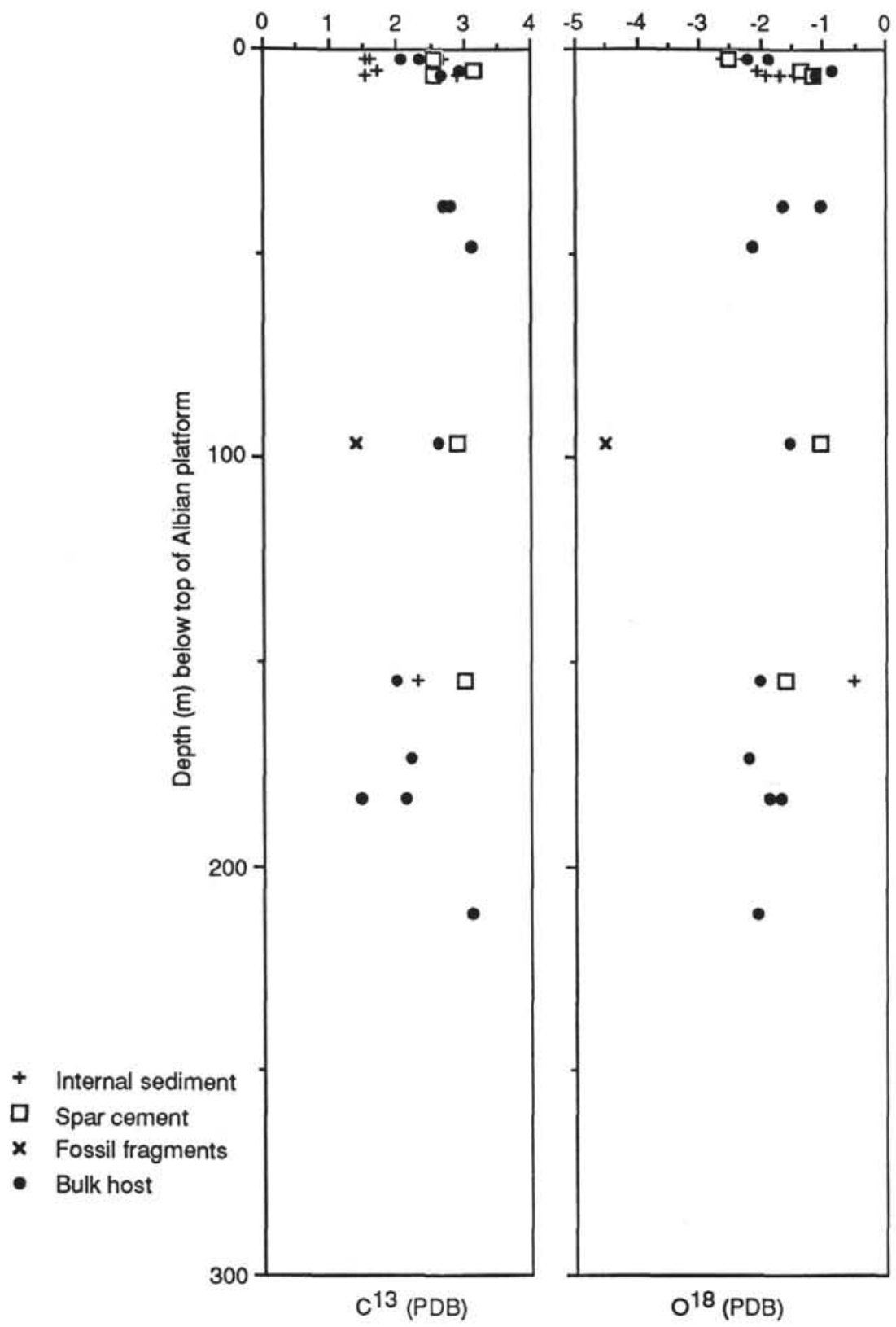

Figure 17. Stable isotopic values of carbon and oxygen at Site 865 (Allison Guyot). The data are plotted vs. depth below the top of the Albian platform to show stratigraphic variation of the isotopic ratios. No clear difference between the upper and lower parts of the section can be seen. In general, samples of spar cement that fill moldic porosity show slightly higher (more positive) isotopic ratios for both carbon and oxygen.

Reflection profiler and $3.5 \mathrm{kHz}$ echo-sounder records show that most of the summit region of Resolution Guyot is covered by a blanket of pelagic sediments, generally from 10 to $25 \mathrm{~m}$ thick, but as much as $75 \mathrm{~m}$ thick in some of the depressions (Fig. 19). Only around the perimeter of the guyot and on a few central peaks does the Albian carbonate platform limestone show through from beneath the pelagic cover.

Contours drawn on the unconformity separating the pelagic cover from the underlying Albian platform limestone (Fig. 20) shows the morphology of the surface. Some of the main features seen on the contour map are

1. A general cross-sectional form of the guyot that is asymmetric, with the shallower side on the southwest.

2. A northwest-trending ridge on the west-central part of the guyot, parallel to the southwest edge of the guyot. Smaller ridges parallel the main ridge farther to the east.

3. An encircling, nearly-continuous outer rim, with a moat-like trough 1 to $2 \mathrm{~km}$ behind it. The moat is typically 30 to $40 \mathrm{~m}$ deeper than the summit of the adjacent rim and about 0.5 to $4 \mathrm{~km}$ wide, within closed contours. Both the rim and moats are deeper on the east than on the west side of the guyot. The deepest section of moat is within the northern cape, where Site 866 is located in the moat and Site 867 is on the adjacent rim.

4. Smaller relief features complicate the domical surface, which is pitted by many oval depressions, some partly or wholly filled by pelagic sediments. One of these, in the east-central sector, is about 80 $\mathrm{m}$ deep. Seismic-reflection profile data (Fig. 21) show that the slopes of the depression truncate adjacent reflectors in the limestone.

Within the central part of the guyot, the broadly domical surface follows the form of the arched seismic reflectors within in the platform limestone (Fig. 21). In detail, the surface of the platform limestone near Site 866 can be seen (Fig. 22) to rise toward the central part of the guyot in a series of broad steps sloping gently outward, parallel to the seismic reflectors. In places, risers separate the steps. As seen 


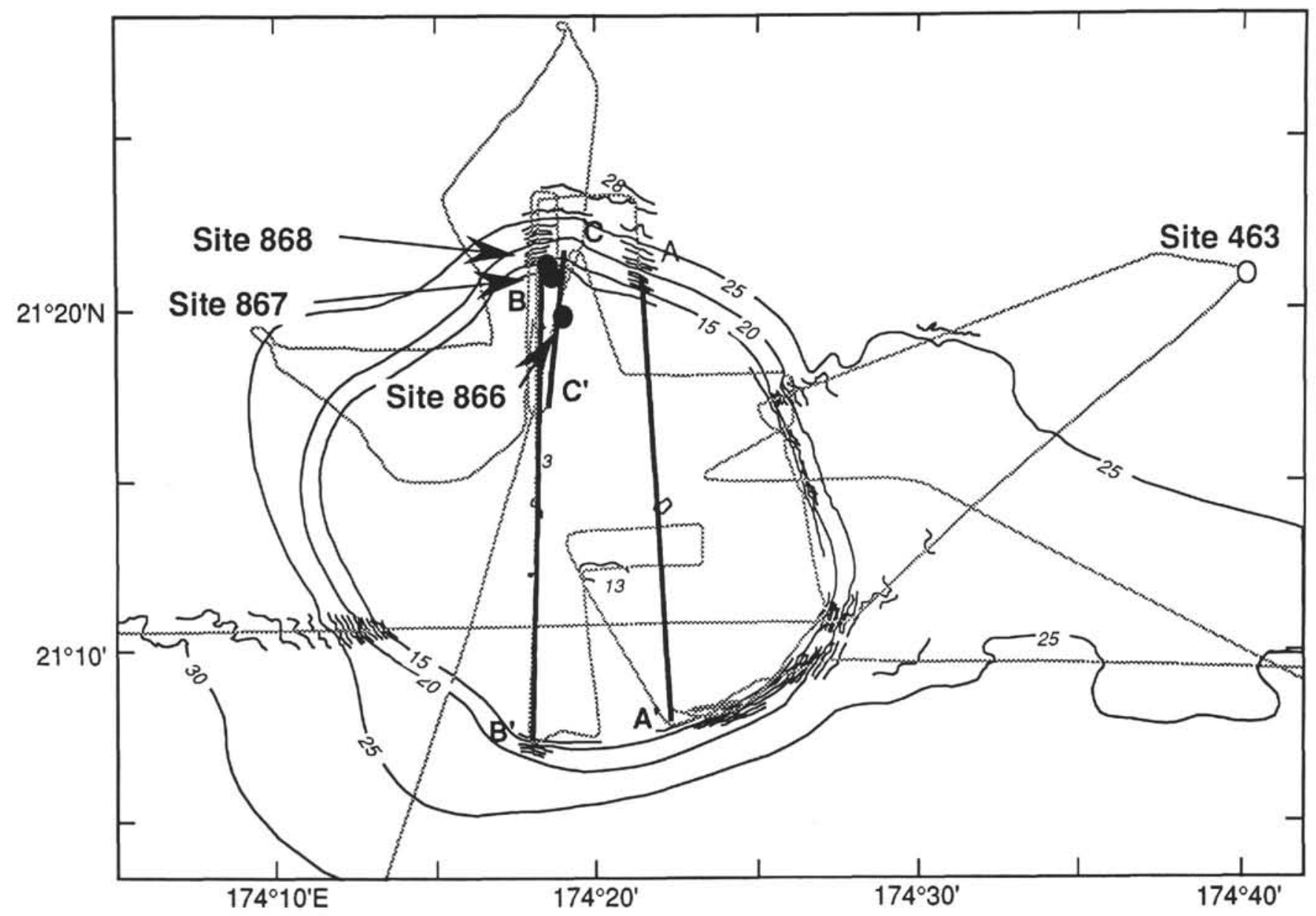

Figure 18. Generalized bathymetry of Resolution Guyot, with location of drill sites for Leg 143 and DSDP Site 463 . Contour interval, $500 \mathrm{~m}$ (bold lines), with 100-m contours locally. From surveys by Thomas Washington during SIO Roundabout cruise, Leg 10, and from JOIDES Resolution during Leg 143. Location of ship's tracks shown, with heavy lines showing location of profiles in subsequent figures.

on the reflection profile across the entire guyot (Fig. 21), the undulating reflectors within the uppermost part of the limestone succession are truncated here and there, in no systematic pattern, by the unconformity at the base of the pelagic strata.

Seaward from the perimeter rim, there is commonly a narrow $(0-200 \mathrm{~m})$ terrace about $30 \mathrm{~m}$ deeper than the top of the rim. The terrace shows in several profiles that cross the platform edge (Fig. 22) and was crossed by JOIDES Resolution during the slow transit from Sites 867 to 868 . The depth recorder showed a steep $\left(>25^{\circ}\right)$ escarpment about $25 \mathrm{~m}$ high between the rim and the terrace, and then a very gradual outward slope across the terrace, which is encrusted with phosphorite and ferromanganese oxides. Site 868 is located close to the outer edge of this terrace.

We interpret the arched, undulating form of the topography of the central part of the guyot as due mainly to differential compaction of limestone (and clay?) over buried volcanic ridges beneath the sedimentary section. At all three drill sites on Resolution Guyot, and in all dredge samples from the guyot (van Waasbergen, this volume) the uppermost layers of limestone sampled were of very shallow-water facies, which indicates that the carbonate platform was virtually flat and essentially at sea level when deposition ceased. This, in turn, implies that the present-day broad relief of the unconformity between platform limestone and overlying pelagic strata has developed as a result of post-Albian, continuing compaction of the platform limestone over the relief on the underlying volcanic basement.

The small-scale depressions and hills on the surface of the platform we interpret as parts of an erosional surface shaped in a subaerial environment, where dissolution of the limestone by meteoric waters left sinkholes and isolated knobs of resistant limestone. The steps on the surface are likely the result of differences in erosional resistance of successive limestone strata. The available seismic and bathymetric data are insufficient to test the hypothesis that the steps are parts of encircling marine terraces, cut during a stepwise fall in sea level. The terrace seaward of the rim at Site 868, we do interpret as a wave-cut bench, with a steep sea-cliff at the back. The bench marks the level of the sea during the time of maximum emergence of the limestone platform. A minimum estimate of the height of the platform above sea level during emergence can be obtained from the depth of sinkholes, which we assume formed in a subaerial environment. The local relief from the top of the small peak in the east-central part of the guyot to the bottom of the sinkhole about $2 \mathrm{~km}$ south of the peak is about 110 m (Fig. 19, upper panel). An unknown thickness of limestone, originally stratigraphically above the top of the hill, may also have been removed by erosion, and thus, only a minimum of $110 \mathrm{~m}$ can be estimated for the relative drop in sea level at this guyot.

We interpret the elevated rim that encircles the platform and gives the guyot its atoll-like appearance as an erosional remnant formed because of the differential rates of subaerial dissolutional erosion of the platform limestone close to the steep outer slopes of the guyot as opposed to rates on the limestone on the relatively flat interior of the platform. At Resolution Guyot, the interior became pocked by sinkholes and dotted with a few resistant knobs, but then later on, in postAlbian time, was gradually deformed by differential compaction. Drilling on the rim, at Site 867, showed the presence of typical quiet- 

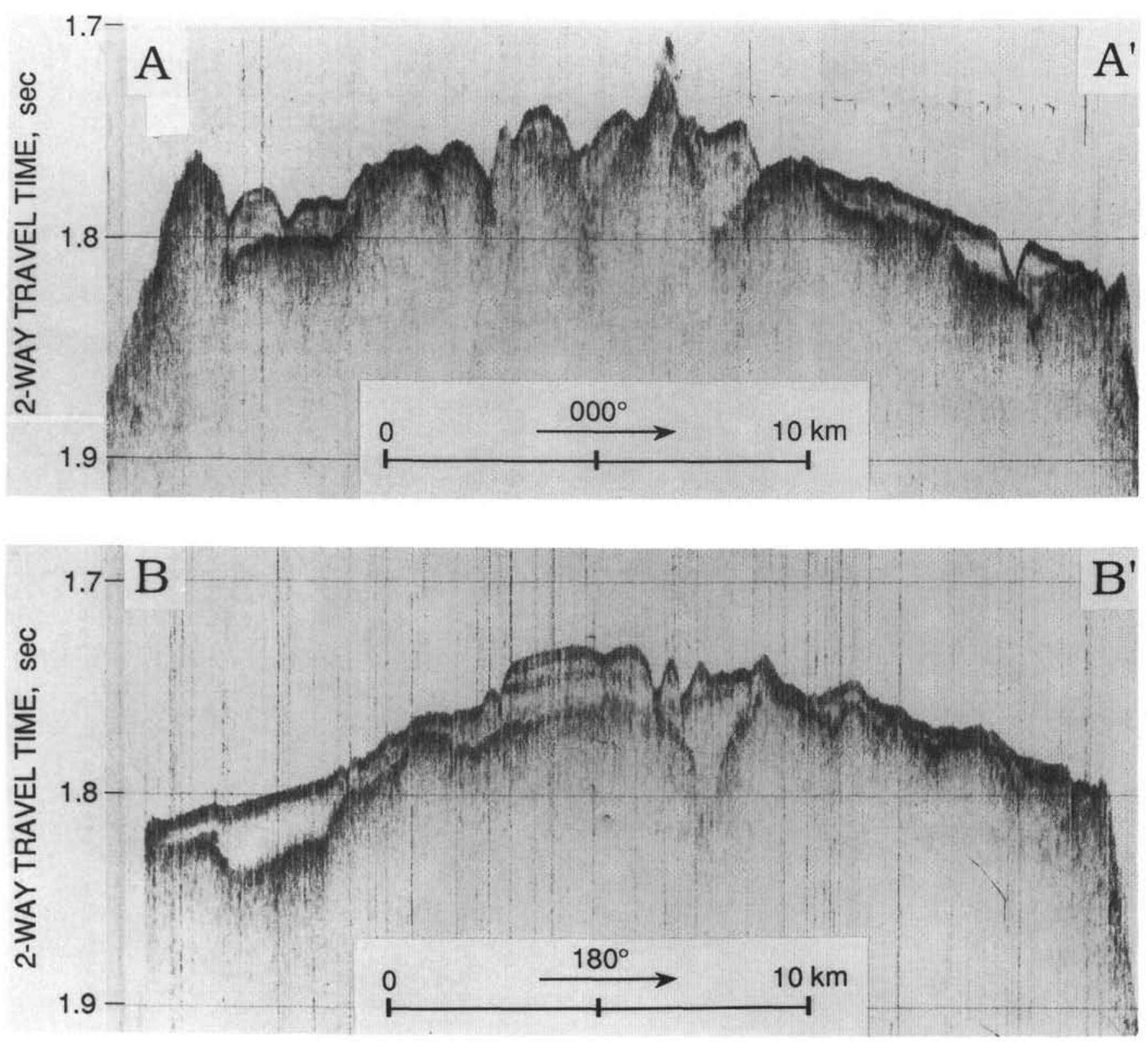

Figure 19. 3.5-kHz reflection profiles across Resolution Guyot along lines A- $\mathrm{A}^{\prime}$ and $\mathrm{B}-\mathrm{B}^{\prime}$ in Figure 18. The pelagic sediments are acoustically nearly transparent, and the prominent reflector is the top of the Albian platform limestone. Both profiles show the marginal rim and the moat behind it. Profile A-A' shows a prominent rim along the left (south) side of the guyot and a remnant peak of Cretaceous platform limestone near the center, with a nearby pelagic-sediment-filled depression. Profile B-B' crosses a pelagic-sediment-filled moat near the left (north) side of the guyot, where Site 866 is located, and a pelagic sediment-filled depression near the summit of the guyot. Profiles taken from Thomas Washington during SIO Roundabout cruise, Leg 10. Vertical exaggeration at seafloor about $67 \times$.

water, platform-interior deposits, interrupted by intervals of storm and foreshore deposits, but with no in-situ biohermal accumulations.

\section{Petrography and Geochemistry of Core Samples from Upper Parts of Limestone}

The upper part of the shallow-water section drilled at Site 866 is lithologically similar to the one drilled on Allison Guyot (Site 865). The dominant lithofacies are fine-grained lime wackestone and packstone of Albian age, deposited in shallow, quiet-water environments with good connections with the open-marine environment, as evidenced by the abundance of mollusks, echinoids, ostracodes, sponges and sponge spicules, and dasycladacean algae that make up the bulk of the grains in these deposits (Shipboard Scientific Party, 1993b). Because the summit morphology of Resolution Guyot suggests that the top 80 to $100 \mathrm{~m}$ of the shallow-water section was partly eroded subaerially prior to drowning, we investigated the diagenetic history of the top portion of the succession recovered at Site 866.

As at Site 865 , core recovery was sparse in the top portion of the shallow-water limestones at Site 866 . The main diagenetic characteristic of these sediments is moldic porosity, especially of mollusk shells and the calcified remains of green algae. None of the recovered intervals at Site 866 contained geopetal, internal-sediment-filled cavities like those on Allison Guyot. Visible diagenetic effects other than moldic porosity include thin, synsedimentary, calcrete-like exposure bands that occur at irregular intervals within the lagoonal mud sequences and open, burrow-like cavities that are commonly coated with yellow-stained spar or filled with white, chalky sediment.

An example of typical porous packstone textures can be seen in Sample 143-866A-6R-CC, 17-19 cm (Fig. 23). Algae and mollusk fragments are preferentially dissolved, whereas echinoid grains are 


\section{E.L. WINTERER ET AL.}

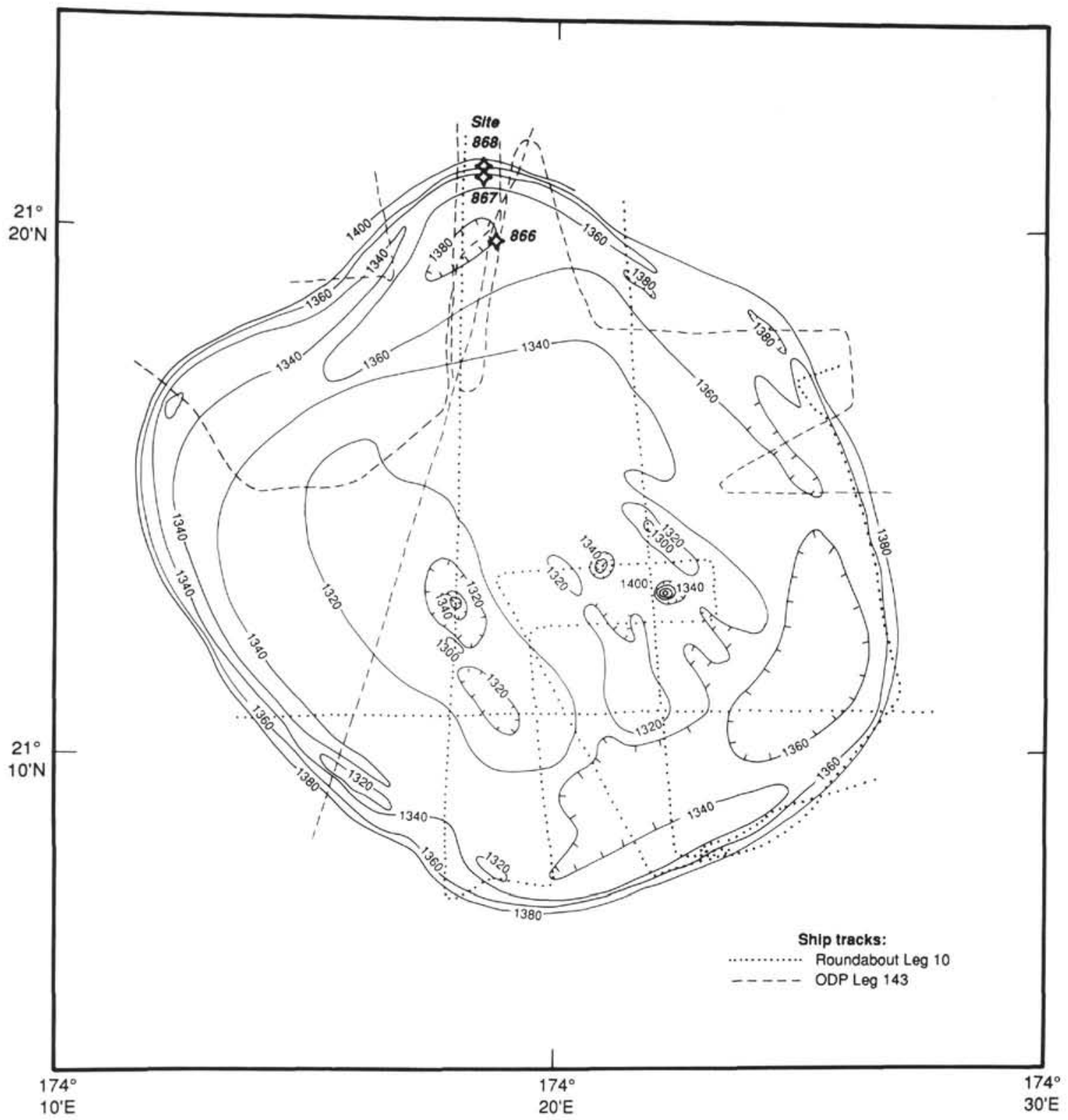

Figure 20. Contour map showing topography on the upper surface of the Lower Cretaceous platform limestone. Control from multibeam and 3.5-kHz echo-soundings and seismic profiles collected from Thomas Washington during SIO Roundabout Cruise, Leg 10, and from JOIDES Resolution during Leg 143. Contour interval, $20 \mathrm{~m}$. A velocity of $1600 \mathrm{~m} / \mathrm{s}$ is used to estimate depths where the limestone is buried by pelagic sediments; where the surface is not buried, a velocity of $1500 \mathrm{~m} / \mathrm{s}$ is used.

preserved, and in many places are overgrown with syntaxial spar cement. Minor fracturing is visible in some intervals. The fractures extend a few millimeters to a few centimeters, and are discontinuous. Most are filled with coarse, clear, equant spar cement. In many places, open, unfilled secondary pore space occurs alongside molds that are completely occluded with equant spar cement. This suggests possibly two separate stages of dissolution, with an episode of cementation between. Most of the second-stage, unfilled porosity is in the form of molds and solution-enhanced molds. No solution-enhanced molds were observed that were filled with cement.

In several intervals, there are thin alteration zones that we interpret as synsedimentary. These take the form of thin (1-2 mm), gray, micritic bands that form irregular surfaces within some limestone samples. An example of these is seen in Figure 24, from Sample $143-866 \mathrm{~A}-25 \mathrm{R}-1,41-42 \mathrm{~cm}$. These bands typically show one boundary that is gradational into the host wackestone, whereas the other is a sharp, irregular contact that truncates grains in the adjacent sediment. Most likely, these micritic bands represent brief episodes of exposure and calcification of the platform surface that resulted in the precipitation of authigenic micrite in the uppermost exposed layers. Isotopic analyses of these bands (Table 2) do not indicate any significant change in fluid composition between the authigenic micrite and the surrounding host wackestone. Only a slight (less then $1 \%$ ) negative shift in $\delta^{18} \mathrm{O}$, which could be attributable to a slight rise in temperature or to alteration by water with low $\delta^{18} \mathrm{O}$, but with a very low water/rock ratio.

In summary, the samples from the upper part of the section at Site 866 show less diagenetic maturity than those at Allison Guyot. The common observable diagenetic sequence is a three-stage dissolutionprecipitation-dissolution pattern, wherein secondary (moldic) porosity is created and then filled with clear, equant spar cement. Finally, more moldic, as well as nonfabric-selective vuggy, porosity that 


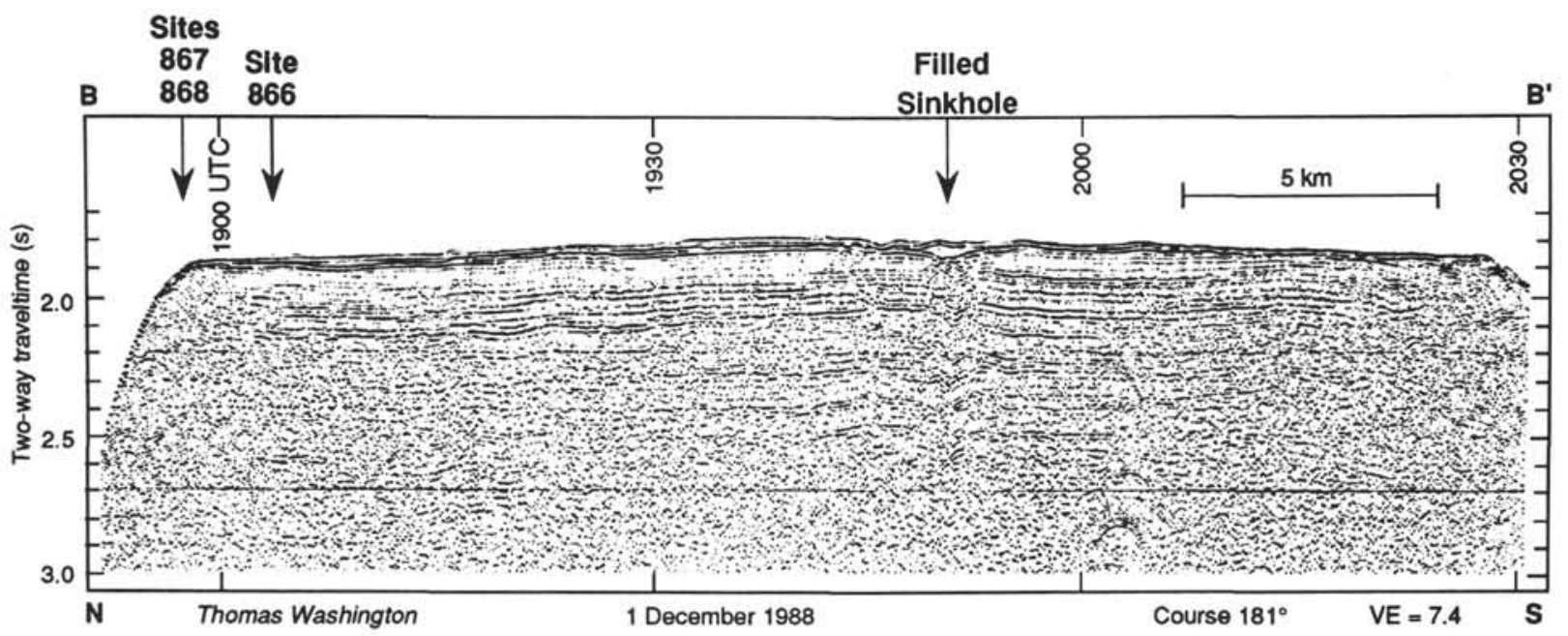

Figure 21. Seismic profile across Resolution Guyot (B-B' in Fig. 18) showing the general arching of seismic reflectors over the south-central part of the guyot, and the deep pelagic-sediment-filled depression. Reflectors in the platform limestone are truncated by the erosion surface that delimits the depression. Profile taken from Thomas Washington on SIO Roundabout Cruise, Leg 10. Vertical exaggeration at seafloor about $7 \times$.

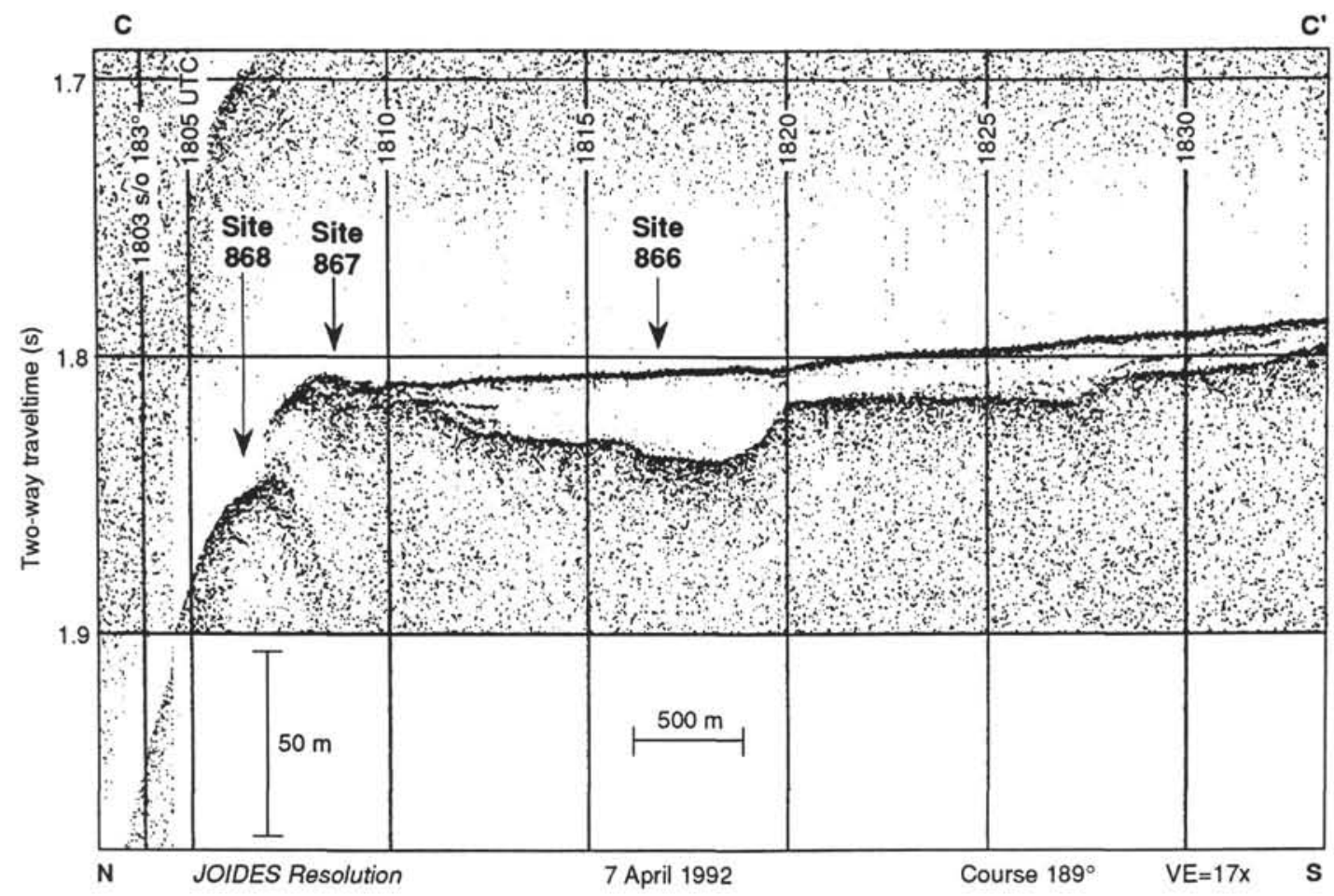

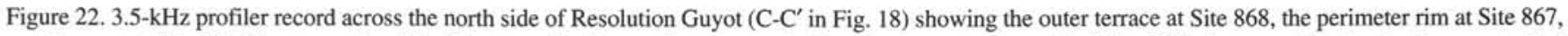
and the moat at Site 866. The stepped profile of the top of the Lower Cretaceous platform limestone to the south of Site 866 is interpreted as having been controlled by differential erosion of limestone strata during emergence. Profile taken from JOIDES Resolution during Leg 143 . Vertical exaggeration at seafloor about $17 \times$.

remains largely unfilled is created. Primary pore space, largely in the form of intragranular pores, such as chambers of foraminifers and cellular algae, is filled with fine equant spar cement. Noteworthy diagenetic features include the occurrence of micrite bands, 1 to $2 \mathrm{~mm}$ thick, that appear to be thin, incipient calcrete layers, formed during episodic, brief exposure events that interrupted normal shallow-water carbonate sedimentation at this site.

Sites 867 and 868 are located near the north edge of the summit platform of Resolution Guyot (Fig. 22). Site 867 penetrated $77 \mathrm{~m}$ into the top of the Cretaceous carbonate section, at a spot where the platform limestones form a generally continuous rim that stands 20 to $40 \mathrm{~m}$ above the surrounding platform. Site 868 was located on a small terrace on the uppermost slope of the guyot, about $400 \mathrm{~m}$ outward from Site 867 (Fig. 22). Core recovery at both sites was markedly better than at Sites 865 and 866 , with recovery rates of $20 \%$ to $60 \%$ over short intervals.

Lithofacies recovered at these sites include mudstone, packstone, grainstone, and floatstone with abundant coarse skeletal material, including rudist bivalves, sponges, and corals (Shipboard Scientific Party, 1993c). These are overlain by a thin crust of phosphatized 


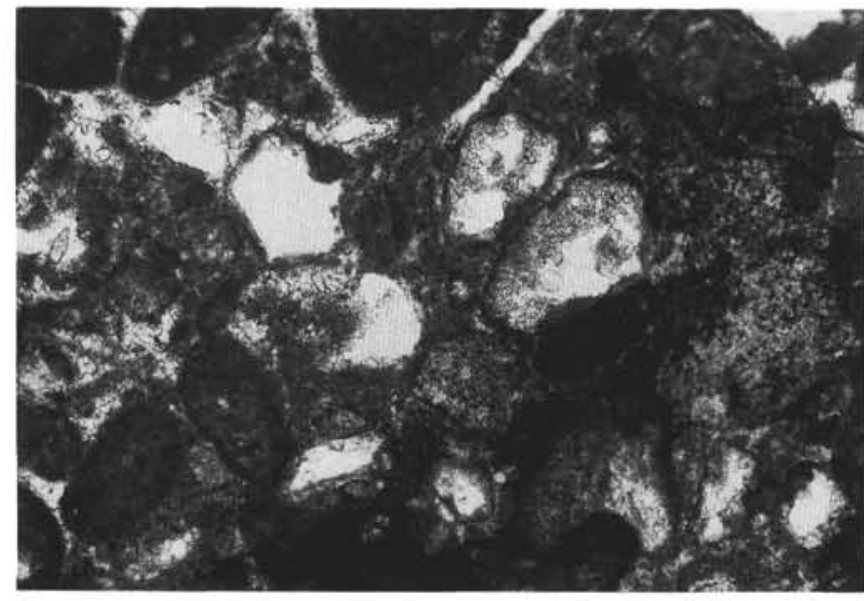

$0.5 \mathrm{~mm}$

Figure 23. Thin-section photomicrograph of Sample 143-866A-6R-CC, 17-19 $\mathrm{cm}$, showing the texture of skeletal packstone with abundant moldic porosity. Most of the molds consist of micrite envelopes surrounding pore space that remains empty, or, in many places, is filled with finely crystalline, equant, calcite cement. Scale bar is $0.5 \mathrm{~mm}$.

pelagic sediments and ferromanganese oxide deposits. Compared to the material recovered at the other sites on Resolution Guyot, these rocks include a far greater proportion of coarse-grained material, as well as abundant whole or nearly whole rudist shells and calcareous sponges that appear to be in life position.

The primary diagenetic feature of these deposits is the presence of large, centimeter-sized cavities that are wholly and partly filled with fine-grained internal sediment and authigenic crystalline cement. In many cavities, sediments form thin, brown (phosphatic) to white laminae with geopetal orientations in the lower parts of the cavity, whereas the open, upper parts of the cavity are lined with successive generations of coarse, crystalline spar cement.

A good example of a fairly complete diagenetic sequence can be seen in Sample 143-867B-4R-3, 120-123 cm. This sample consists of pelletal wackestone with abundant skeletal fragments, mostly of mollusks, algae, and echinoderms (Fig. 25). Within this sample, abundant moldic porosity forms interconnected cavities from where centimetersize bivalve shells have dissolved. Geopetally filling these pores is shallow-water-derived, pelletal mud with bioclastic fragments. In many places, the mud is succeeded by unfossiliferous crystal silt made of equant, 20-mm calcite crystals. In some places, the remainder of the secondary pore space is filled by coarse crystalline calcite cement that overlies the first, shallow-water-derived internal sediment. In other places, enhanced moldic porosity remains open and is thinly coated with phosphatized pelagic material (Fig. 26).

Many cavities, especially in the upper part of the section above Core 143-867B-5R, are partially to completely filled with fine-grained phosphatic sediments. In some places, these form isolated pebbles in the cores, some of which, including one from Sample 143-867B-2R-1, $60-62 \mathrm{~cm}$, show evidence that the phosphatic material not only includes fine-grained phosphatic internal sediments, but also that phosphatization has affected the in-situ host sediments as well (Fig. 27). No internal sediments of pelagic origin were observed below Core 143 867B-5R ( $24 \mathrm{~m}$ below the top of the shallow-water section).

The grainstone intervals recovered at Sites 867 and 868 commonly show well-developed, early marine cementation that has occluded all primary porosity with sparry calcite. The cements typically consist of two types: early, fringing, fibrous cement that coats sediment grains, and clear, blocky calcite spar that fills the remainder of the pore space between these grains. The early, fringing spar may originally have been aragonitic, but was altered to more stable calcite,

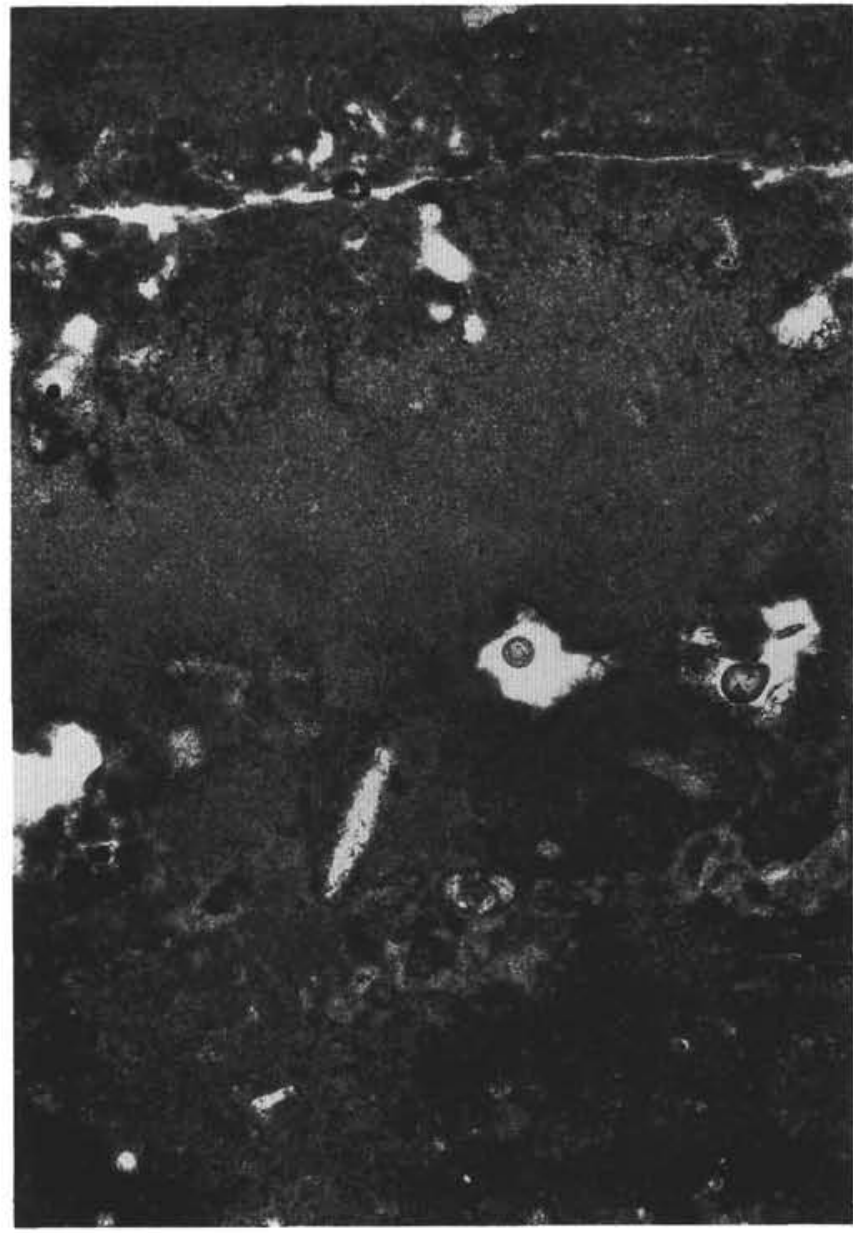

$0.5 \mathrm{~mm}$

Figure 24. Thin-section photomicrograph of Sample 143-866A-25R-1, 41-42 $\mathrm{cm}$, showing a cross section of a thin (about $1 \mathrm{~mm}$ ) layer of incipient calcretization that indicates a brief exposure episode during the depositional history of the shallow-water section. One boundary of the micrite band is gradational (bottom, with small miliolid foraminifer), whereas the other one is more abrupt and has narrow tendrils of the overlying mudstone that extend into the micrite band (near top). Moldic porosity is common throughout. Scale bar is $0.5 \mathrm{~mm}$.

leaving a coarser crystal structure with many microinclusions (cloudy spar). An example of this can be seen in Sample 143-867B-1R-3, 34-39 cm (Fig. 28). Many of the mollusk shell fragments in these deposits retain a fine, laminar microstructure, but others have been neomorphosed to a coarse crystalline structure in which the fine growth-laminae of the original shell were preserved as ghosts.

A common late-stage cement in some of these deposits, especially in the top parts of cavities filled with laminated, pelagic sediment, is radiaxial, fibrous cement. Examples of this can be seen in Sample 143-868A-3R-1, 46-50 cm, where the cement interrupts laminated, phosphatic, internal sediments of pelagic origin that fill a large cavity in algal-mat deposits (Fig. 29).

A few intervals associated with large cavities show an uncommon form of alteration of the host sediments. A spectacular example of this is in Section 143-867B-4R-1, 123-130 cm (Figs. 30 and 31). This interval includes a cavity nearly $5 \mathrm{~cm}$ in diameter that is partially filled with several generations of crystalline cement. The shape of the cavity appears constrained by the former presence of a large rudist shell, the dissolution of which influenced the size and shape of the cave. The rudist shell was in a well-cemented, pelletal grainstone with abundant, small, skeletal fragments of mollusks. Surrounding the dissolved shell 


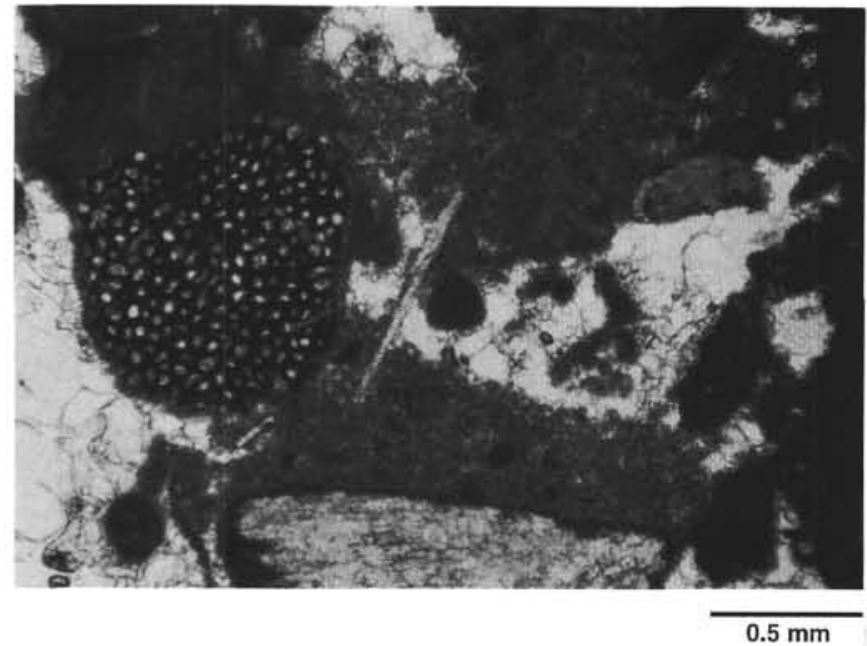

Figure 25. Thin-section photomicrograph of Sample 143-867B-4R-3, 120-123 $\mathrm{cm}$, showing fragments of red algae (dark, cellular) and mollusks (light gray, with some preserved growth-banding). Abundant enhanced-moldic porosity is partially filled with clotted, micritic, internal sediment perched on the skeletal grains, and clear, blocky, crystalline calcite cement. Scale bar is $0.5 \mathrm{~mm}$.

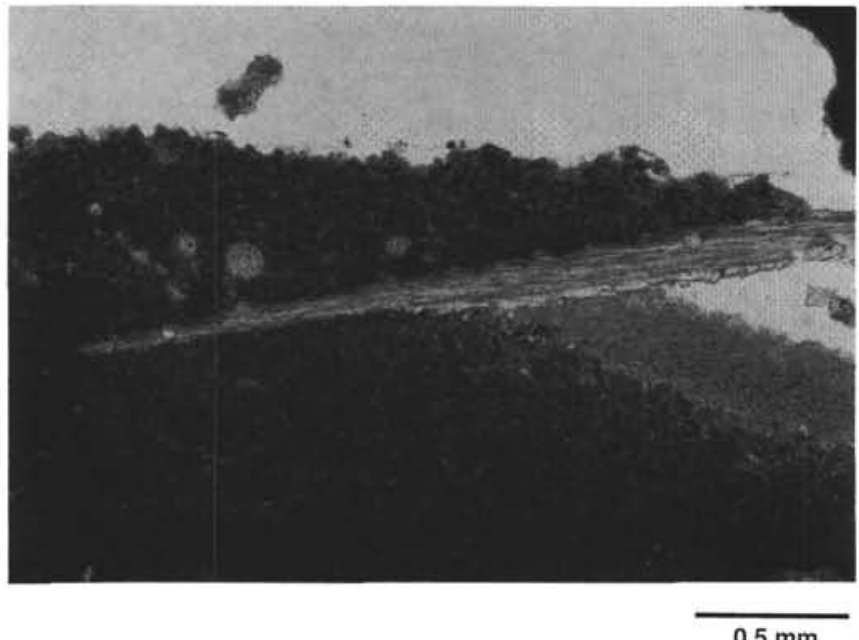

Figure 26. Thin-section photomicrograph of Sample 143-867B-4R-3, 120-123 $\mathrm{cm}$, showing several generations of internal sediment that fill a large cavity in packstone. The earliest clotted micrite (bottom) is overlain by crystal silt (light gray) and partially phosphatic mud that contains poorly preserved planktonic foraminifers (dark gray, with small circular shapes). These are separated by a narrow, elongate fragment of a bivalve shell. The remainder of the cavity remains unfilled (white). Scale bar is $0.5 \mathrm{~mm}$.

is a zone of alteration that extends several centimeters into the host sediment and that is bounded by a 1- to 2-mm-thick micritic band. Inside the zone bordered by this band are micritic particles and skeletal grains similar those in the host pelsparite, as well as micritized algal fragments and the micrite envelopes that surround mollusk skeletal molds. Isolated pockets of clotted micrite occur, but the predominant textural feature is an irregular meshwork of thin $(20 \mathrm{~mm})$ micrite walls that appear to connect detrital grains, in some places spanning gaps more then $1 \mathrm{~mm}$ wide (Fig. 32). The wall structures make arcuate, concavingupward spans and strongly resemble an alveolar texture commonly associated with diagenesis in the vadose zone (Esteban and Klappa, 1983). Alveolar texture is thought to be the result of root-penetration

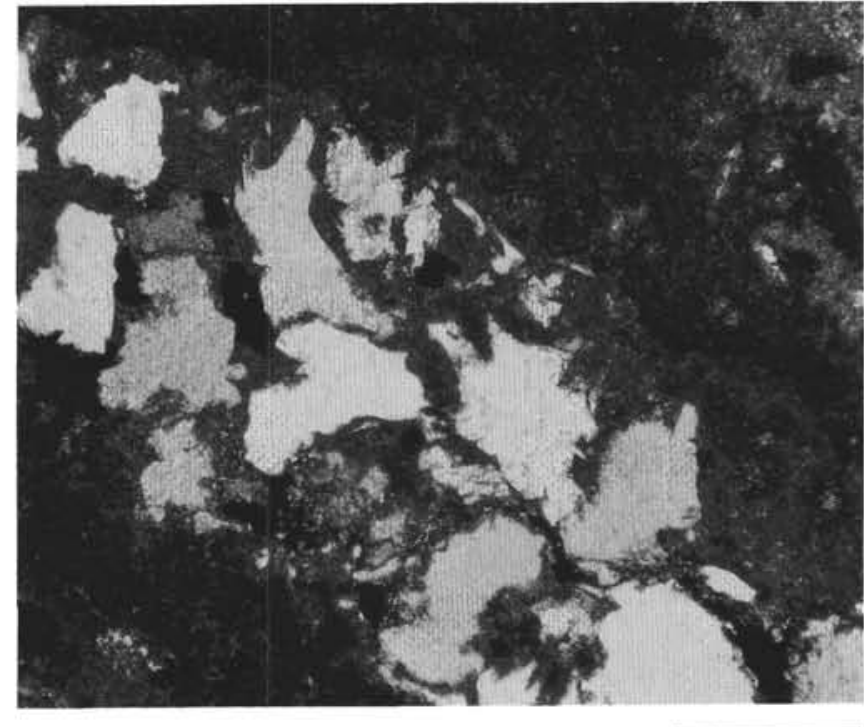

$0.5 \mathrm{~mm}$

Figure 27. Thin-section photomicrograph of Sample 143-867B-2R-1, 60-62 $\mathrm{cm}$, showing crystalline cement in a mold in wackestone that was invaded and replaced by fine grained phosphatic material. This indicates phosphatic sediment not only filters into the cavity spaces of the limestone, but phosphatization also affects in-situ limestone directly. Scale bar is $0.5 \mathrm{~mm}$.

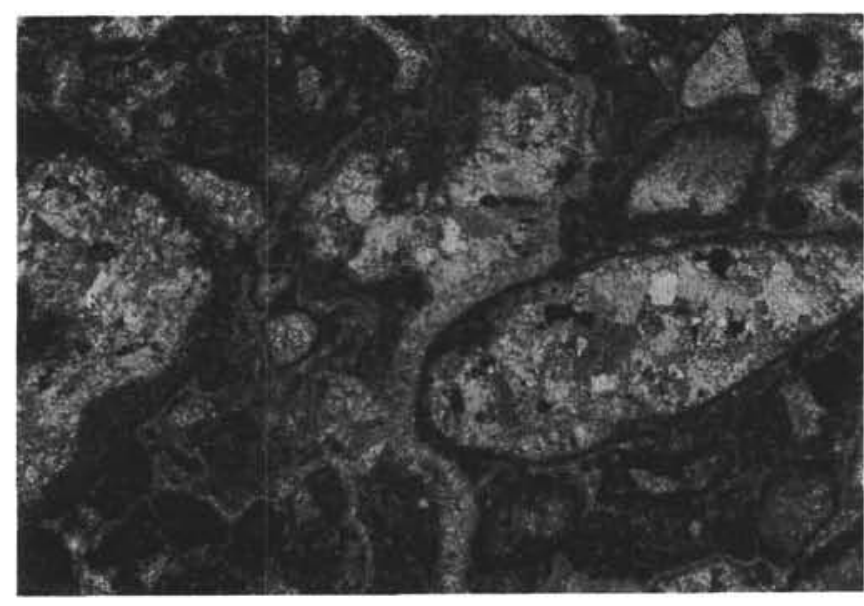

$0.5 \mathrm{~mm}$

Figure 28. Thin-section photomicrograph of Sample 143-867B-1R-3, 34-39 $\mathrm{cm}$, showing the grainstone texture of sand-sized skeletal fragments, with early cementation by isopachous fringing cement that was probably originally aragonitic. Finely clotted micritic mud was introduced subsequent to this early cement, followed, finally, by equant, crystalline spar that filled the remainder of the primary and most of the secondary pore space. Scale bar is $0.5 \mathrm{~mm}$.

in a caliche-like setting. This explanation for the features observed in this sample seems unlikely, because it appeared to have formed through diagenesis fairly deep $(20 \mathrm{~m})$ in a limestone section having no apparent association with a soil profile. The structures might possibly have been formed by encrusting organisms, such as certain foraminifers or algae, but because they appear to occur inside secondary pore space in a dissolved mollusk shell, this too is unlikely. Throughout the altered zone, the micrite walls appear to be consistently oriented in a concaving-upward position, which suggests that their occurrence 


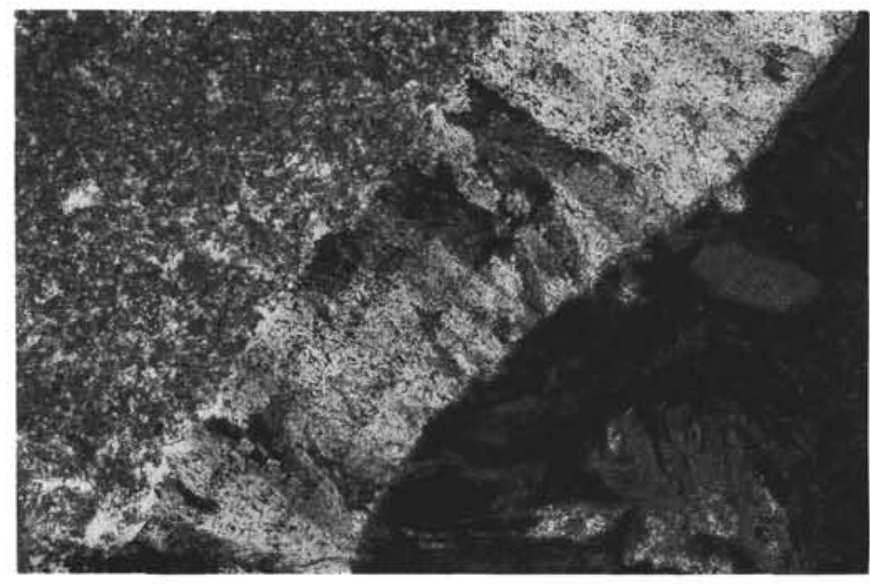

$0.5 \mathrm{~mm}$

Figure 29. Thin-section photomicrograph of Sample 143-868A-3R-1, 46-50 $\mathrm{cm}$, showing radiaxial-fibrous cement crystals that line the wall of a solution cavity in algal-laminated mudstone (dark). The remainder of the cavity is filled with fine mud (light gray) that contains pelagic components (not shown). Scale bar is $0.5 \mathrm{~mm}$.

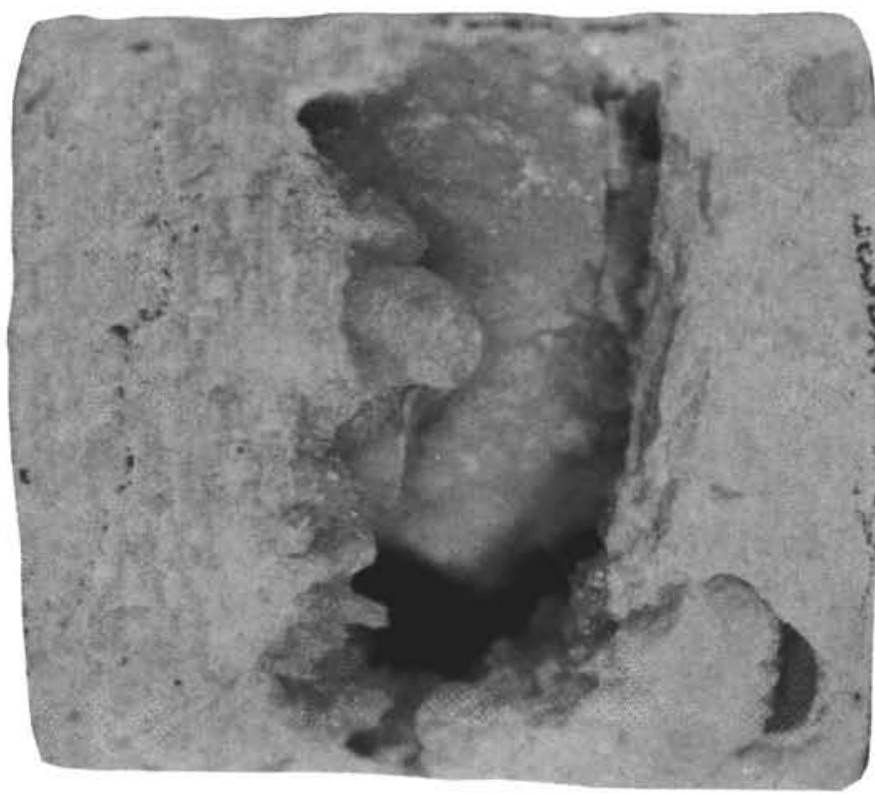

\section{$1 \mathrm{~cm}$}

Figure 30. Close-up of core sample from interval 143-867B-4R-1, 123-130 cm, collected as a whole-round specimen (not cut). A solution cavity several centimeters in diameter in the center of the sample is partially filled with bladed and coarse, dog-toothed, calcite crystals. A small knob resembling a stalagmite rises from the bottom of the cavity. A second, smaller cavity that is partially filled with sandy sediment is visible above the larger one. Scale is in centimeters.

was controlled somewhat by gravity and that they may have precipitated on the surfaces of water droplets during a period of emergence in the vadose zone. The occurrence of perched sediments and pendant micrite (Fig. 33) within the alteration zone further supports this notion.

Stable-isotopic measurements of various components in this sample show a trend of fairly low (negative) $\delta^{18} \mathrm{O}$ values that suggest alteration with nonmarine, isotopically light water, such as fresh water (Fig.

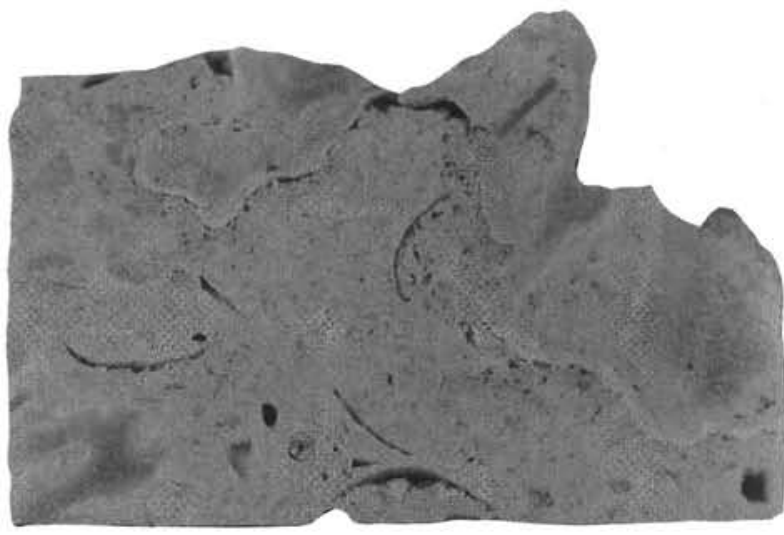

Figure 31. Close-up of core sample from interval 143-867B-4R-1, 123-130 $\mathrm{cm}$, showing the bottom of the large cavity that occurs in this interval. A thin, irregular micrite band (white) separates partially cemented, pelletoidal grainstone (below) from a zone of sediment that has been diagenetically altered in a vadose environment (above). The black line on the scale is $3 \mathrm{~cm}$ long.

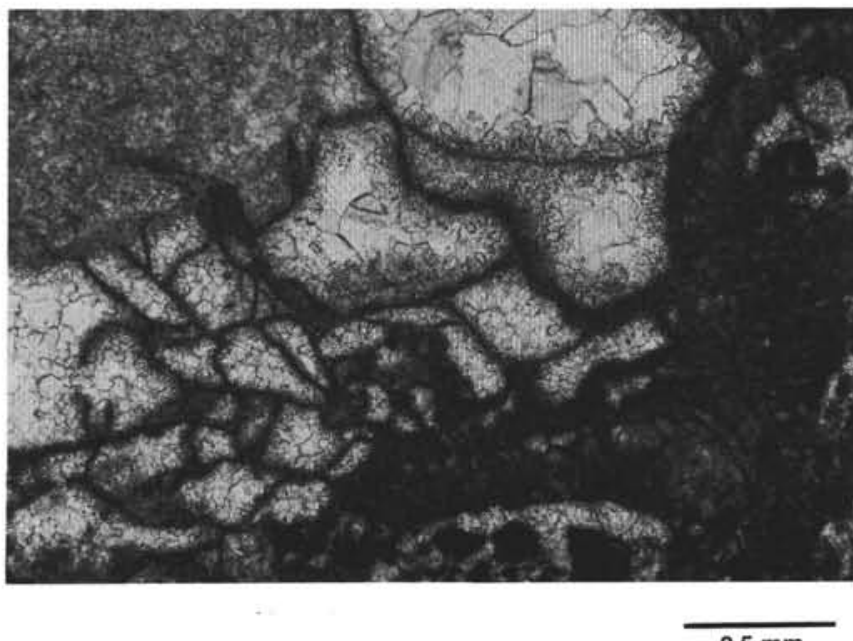

$0.5 \mathrm{~mm}$

Figure 32. Thin-section photomicrograph of Sample 143-867B-4R-1, 123-130 $\mathrm{cm}$, showing concaving-upward walls of micrite that resemble "alveolar" texture. Some of the small chambers in this texture are floored by fine crystal silt. The remaining pore space was filled with coarse, equant, spar cement. The micrite walls bridge a gap created by dissolution of a large mollusk shell. Scale bar is $0.5 \mathrm{~mm}$.

34). The most negative values $\left(\delta^{18} \mathrm{O}<-8.0 \%\right.$ ) were in some coarse, spar cements that formed inside the open-cavity walls, and these may also be associated with cementation in meteoric water. Late-stage spar cement that fills primary pore spaces in the unaltered grainstone gives the highest values for $\delta^{18} \mathrm{O}$, suggesting that they precipitated late in the diagenetic history, in cooler marine waters. Late-stage cavity-filling internal sediments give similar cool-water values for $\delta^{18} \mathrm{O}$.

The basic diagenetic history seen in the material from Sites 867 and 868 is similar to that seen at Site 866 : moldic porosity formed early in the diagenetic history, and was in many places filled with equant spar cement. Some molds were infiltrated by internal sediments, derived first from shallow-water sources, but commonly succeeded by pelagic material. Cavities in which such internal sediments occur are typically 


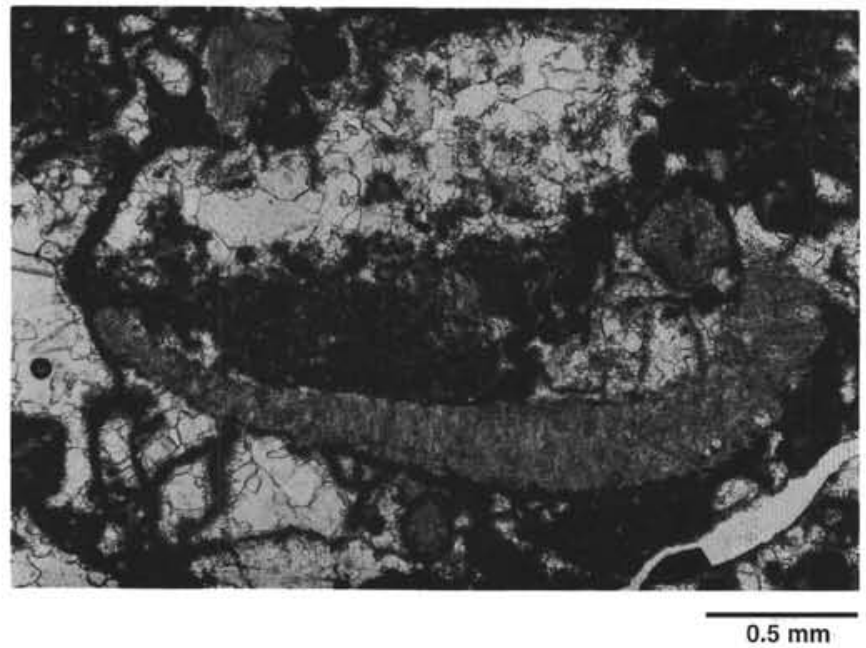

Figure 33. Thin-section photomicrograph of Sample 143-867B-4R-1, 123-130 $\mathrm{cm}$, showing an elongate skeletal fragment with perched, clotted, internal sediment on top, and a rounded, dark, micritic, pendant cement below. Thin, micritic walls resembling "alveolar" texture also visible. Scale bar is $0.5 \mathrm{~mm}$.

not filled with early equant spar and are commonly nonfabricselective, indicating a second episode of secondary-porosity formation, after the first moldic pores had filled with cement. The latest, pelagic, internal sediments are commonly phosphatic. Phosphatization has also affected in-situ deposits and even coarse cements, especially in the top $20 \mathrm{~m}$ of the section.

In coarse-grained intervals, early cementation by aragonitic fibrous cements occurred, resulting in beach-rock-like textures. Such grainstone intervals appear to be well cemented. The latest stage of cementation appears to have followed, or coincided with, the deposition of phosphatic pelagic sediment. These coarse radiaxial-fibrous spar cements line the walls and roofs of solution cavities and most likely formed during continued subsidence of the guyot top into deeper waters.

\section{Stable Isotopic Analyses}

Samples from Site 866 (Resolution Guyot) show ranges in isotopic ratios that are similar to those of Site 865 (Table 2; Fig. 35). Values for $\delta^{18} \mathrm{O}$ range between $-6 \%$ and 0 relative to the PDB scale. Most of the samples that yielded values more negative than $-3 \%$ are from fragments of mollusk shells that may not have been in isotopic equilibrium with seawater when they formed and from phosphatic internal sediments, for which the isotopic ratios are suspect because of the presence of carbonate-bearing apatite. Samples of host wackestone and spar cements with oxygen isotopic ratios less than $-4 \%$ occur at great depth in the section, where burial diagenesis may become a factor.

Values for $\delta^{13} \mathrm{C}$ from samples from Site 866 range from $+1 \%$ to $3.5 \%$. There does not appear to be a significant difference between samples from the upper $100 \mathrm{~m}$ and deeper samples (but see Jenkyns, this volume, for a detailed account of $\delta^{13} \mathrm{C}$ variations with depth at Site 866). Stable isotopic ratios for samples from Site 866 indicate that most of the components were precipitated in isotopic equilibrium with normal seawater. There is some suggestion in the oxygen isotopes of increasing $\delta^{18} \mathrm{O}$ in younger diagenetic components (bulk host vs. spar cements) that may signify diagenesis over a long period of time, from warm surface waters to cooler deeper waters.

Results of isotopic analyses of a small number of samples from Sites 867 and 868 are shown in Tables 3 and 4 and in Figures 34 and 36. At Site 867, somewhat negative values of $\delta^{18} \mathrm{O}$ are found in an interval that appears to be dominated by the results of vadose-zone diagenesis, which produced unusual textures of meniscus and drip-

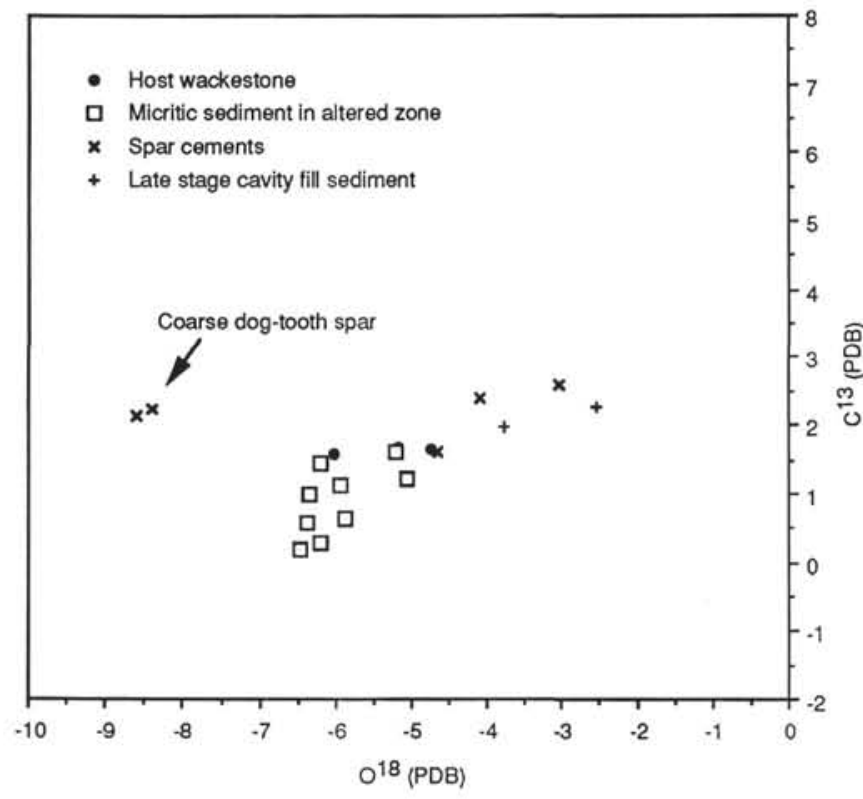

Figure 34. Stable isotopic values of different components sampled from interval 143-867B-4R-1, 123-130 cm (Resolution Guyot), showing distinctly more negative oxygen isotopic ratios for materials from the zone affected by vadose diagenetic processes.

stone cements, as discussed above. The samples from Site 868 were taken from intervals in which a great deal of internal sedimentation could be observed within complex interconnected cavities. These samples were dominated by the presence of early (shallow-waterderived) and late (pelagic-derived, phosphatic) internal sediment and an abundance of late-stage radiaxial spar cement. The values of $\delta^{18} \mathrm{O}$ and $\delta^{13} \mathrm{C}$ from these samples range from $-3 \%$ to $-1 \%$ and from $+1.5 \%$ to $+3 \%$, respectively, and reflect the origin of these components in equilibrium with normal seawater.

\section{"Jacqueline" Guyot}

The informally named "Jacqueline" Guyot (Ja in Fig. 1A) was surveyed during Scripps Institution of Oceanography (SIO) cruise Aries, Leg 5, and then again, using a multibeam echo-sounder, during SIO cruise Roundabout, Leg 10, both on the Thomas Washington. The combined data from both cruises (Fig. 37) shows the bathymetry of the summit region of the guyot. The general form is an elongate dome with its shallowest part, in the north central region, about 150 $\mathrm{m}$ higher than the average depth of the break in slope at the edge of the summit.

In cross section (Fig. 38), the Cretaceous shallow-water limestone beds are seen to be overlain by a discontinuous blanket of younger pelagic sediments. The unconformity between platform limestones and pelagic sediments has considerable local relief. A contour map of this surface (Fig. 39) shows that the limestone in the central part of the guyot has been carved by erosion to a depth of about $50 \mathrm{~m}$ below the general domical surface, creating a wide valley that heads in the west-central part of the guyot and curves down and around to the northeast edge of the guyot. The upper part of this valley is now a closed, elongate depression. Where the older limestones are not covered by pelagic sediments (e.g., at the south end of the guyot), multibeam bathymetric data show a complex erosional surface, including a narrow winding valley. A narrow perimeter ridge edges the guyot along its southeast rim.

We interpret the general elongate domical form of the guyot as the result of differential compaction of limestone layers over an underlying basement volcanic ridge. The basement ridge is visible on the 
Figure 35. Stable isotopic values of carbon and oxygen at Site 866 (Resolution Guyot). The data are plotted vs. depth below the top of the Albian platform to show stratigraphic variation of the isotopic ratios. No clear difference between the upper and lower parts of the section can be seen.

Table 4. Stable isotopic analyses of samples from Site 868.

\begin{tabular}{|c|c|c|c|c|}
\hline $\begin{array}{l}\text { Core, section, } \\
\text { interval }(\mathrm{cm})\end{array}$ & $\begin{array}{l}\delta^{13} \mathrm{C} \\
(\%)\end{array}$ & $\begin{array}{l}\delta^{18} \mathrm{O} \\
(\%)\end{array}$ & Sample description & $\begin{array}{l}\text { Depth } \\
\text { (mbsf) }\end{array}$ \\
\hline \multicolumn{5}{|l|}{$143-868 \mathrm{~A}-$} \\
\hline IR-2, 64-66 & 2.457 & -2.367 & Pebble of brown limestone & 2.15 \\
\hline $1 \mathrm{R}-2,64-66$ & 2.553 & -2.439 & White sediment & 2.15 \\
\hline $1 \mathrm{R}-2,64-66$ & 2.328 & -2.716 & Spar layer below white sediment & 2.15 \\
\hline IR-2, $64-66$ & 2.169 & -2.469 & Reddish host limestone & 2.15 \\
\hline $1 \mathrm{R}-2,64-66$ & 2.245 & -2.781 & White internal sediment in reddish host & 2.15 \\
\hline $1 \mathrm{R}-2,64-66$ & 2.193 & -2.780 & Pelsparite pocket & 2.15 \\
\hline $1 \mathrm{R}-2,64-66$ & 2.148 & -2.886 & Crystalline clast & 2.15 \\
\hline $3 R-1,46-50$ & 1.961 & -2.759 & Bulk host wackestone (matrix) & 11.60 \\
\hline $3 R-1,46-50$ & 2.650 & -2.860 & Pink mud layer & 11.60 \\
\hline $3 R-1,46-50$ & 2.485 & -2.851 & White rubbly layer & 11.60 \\
\hline $3 R-1,46-50$ & 1.899 & -2.954 & Yellow-brown spar & 11.60 \\
\hline $3 \mathrm{R}-1,46-50$ & 2.446 & -2.130 & Laminated sediment above brown layer & 11.60 \\
\hline $3 R-1,46-50$ & 2.532 & -2.262 & Pelsparite lamina & 11.60 \\
\hline $3 R-1,46-50$ & 2.492 & -1.478 & Fossiliferous internal sediment & 11.60 \\
\hline $3 R-1,46-50$ & 2.602 & -2.021 & Spar cement lining cavity & 11.60 \\
\hline $3 \mathrm{R}-1,46-50$ & 2.627 & -2.067 & Spar on bottom of cavity & 11.60 \\
\hline
\end{tabular}

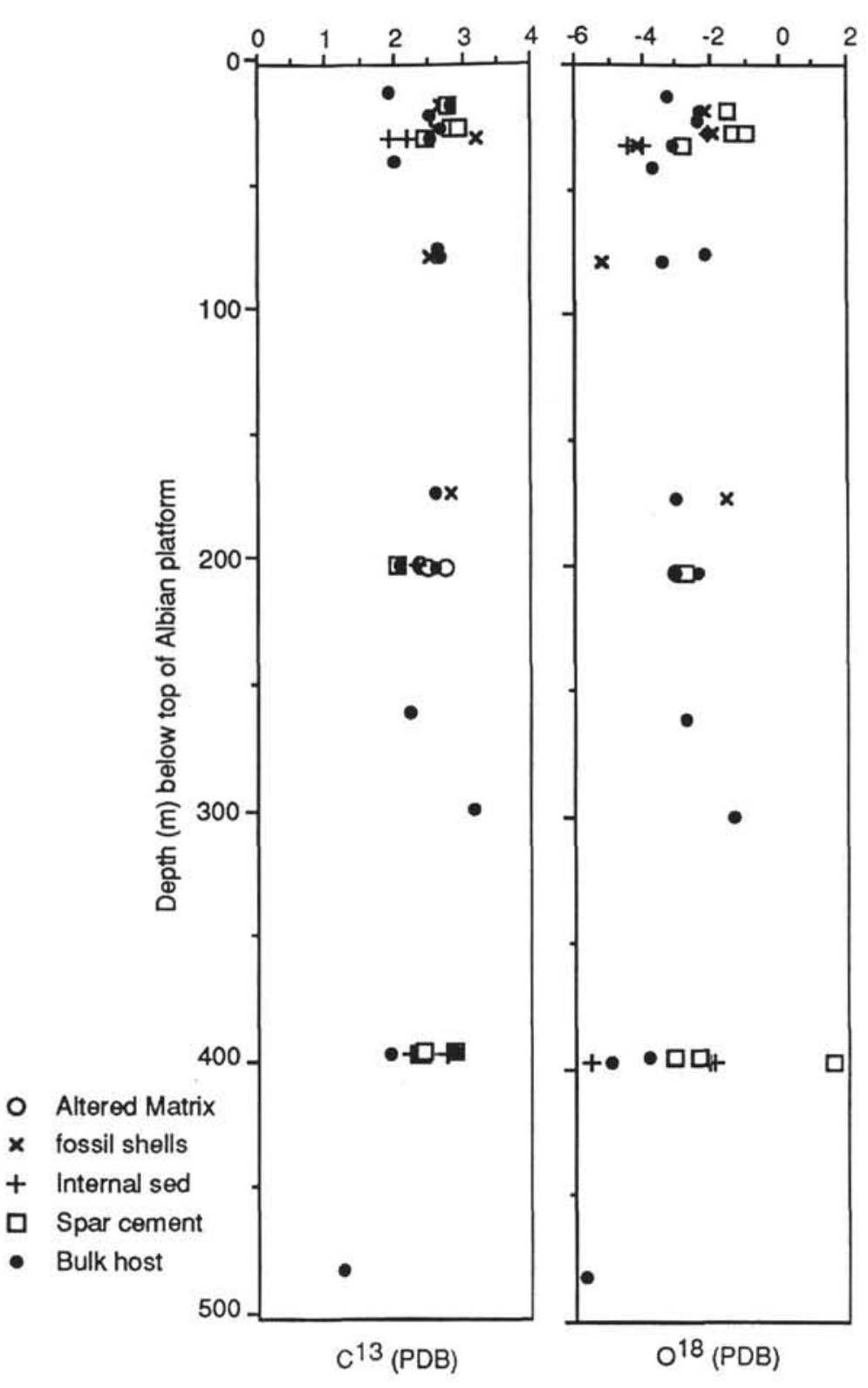

cross section (Fig. 40) beneath a limestone section that increases in thickness from about 0.3 to $0.4 \mathrm{~s}$ TWT, or about 450 to $600 \mathrm{~m}$, using an average sound velocity of $3 \mathrm{~km} / \mathrm{s}$, as determined at nearby Allison Guyot (Shipboard Scientific Party, 1993a).

The relief on the unconformity is partly the result of the arching by differential compaction, but the local, steep relief we ascribe to erosion of the limestone during an episode of emergence, either by streams (small canyons on south part of guyot), or perhaps by wave planation (the large cliffed-rimmed alcove in the central part of the guyot).

\section{"Renard" Guyot}

In plan view (Fig. 41), "Renard" Guyot (Ren in Fig. 1B) is an arcuate seamount, with the dimensions of about $30 \mathrm{~km}$ east-west and $15 \mathrm{~km}$ north-south within the 1900 -m isobath. In cross section (Fig. 42 ), pelagic sediments on the guyot are seen to blanket a buried topography on the underlying Cretaceous platform limestone. Along the eastern arm of the guyot, as shown in the contour map of the buried surface (Fig. 43), the relief consists of a narrow, flat-topped 


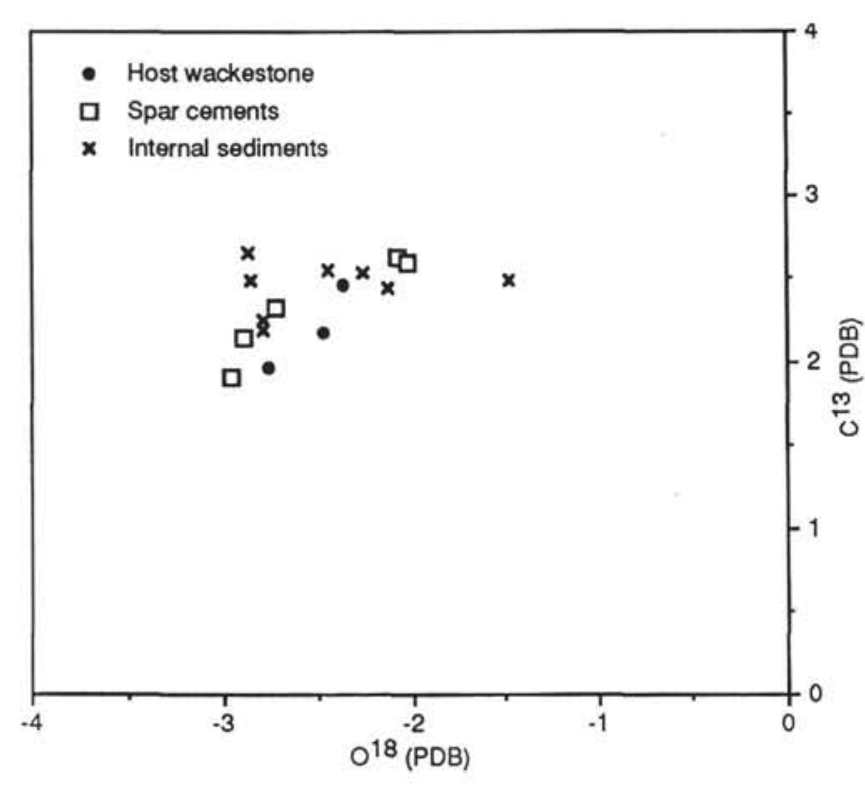

Figure 36. Stable isotopic values of carbon and oxygen at Site 868 (Resolution Guyot). The data fall largely in the field of isotopic values commonly associated with Cretaceous marine surface waters. ridge, separated by a line of steep slopes about $100 \mathrm{~m}$ high from outward-sloping platforms that extend to the break in slope at the edge of the platform. The south side of the guyot is blanketed by pelagic sediments about $1 \mathrm{~km}(1 \mathrm{~s}$ TWT) thick.

The possibility that the steep escarpments seen in the profiles are the result of faulting is negated by the sharp, hairpin trace of the slope (Fig. 43). Instead, we interpret the topography as erosional, and most plausibly, as the result of incomplete wave planation of the guyot during an episode of emergence.

The outward slope of the lower platform surface may partly reflect the original form of the supposed wave-cut bench, but is more likely the result of differential compaction of the underlying limestone strata over a buried volcanic ridge along the axis of the eastern arm of the guyot. The evidence for this is that the erosion surface slopes gently north and south away from the axis, but does not slope westward from the base of the steep slope. Reflectors deeper in the limestone section similarly slope outward from the central axis, and deeper reflectors have steeper dips than shallower layers.

The southwestern part of the guyot presents a somewhat different picture. In cross-section (Fig. 42, right panel), the Cretaceous limestone layers all dip eastward, with deeper layers rising steeply westward near the west edge of the guyot. We suggest that either the underlying volcanic ridge was asymmetric, or that it was truncated, most likely prior to accumulation of the limestone platform, by massive faulting or slumping that carried away the western half of the southern arm of the guyot, leaving only the eastern slopes of the volcanic ridge. Differential compaction of the limestone layers over the sloping volcanic basement surface, in large part following deposition of the topmost limestone beds, imposed the present-day eastward dips.

\section{"Heezen" Guyot}

"Heezen" Guyot, in the westernmost part of the MPM (He in Fig. 1A), was surveyed during the SIO Roundabout cruise, Leg 10, using multibeam and $3.5-\mathrm{kHz}$ echo-sounders and reflection-seismic gear. Essentially, no pelagic sediments can be discerned in the $3.5 \mathrm{kHz}$ records, and thus, the bathymetric map (Fig. 44) is a good representation of the upper surface of the Cretaceous platform limestones on this guyot. At the 20 -m contour interval shown for the summit region, the map shows a surface of low relief, consisting of low hills and shallow closed depressions over the central part of the guyot, and a discontinuous perimeter rim, typically 20 to $40 \mathrm{~m}$ high, around the central region.

In cross section (Fig. 45), a thickness of about $1200 \mathrm{~m}$ of limestone is discernable above the deepest reflector at about $0.7 \mathrm{~s}$ beneath the seafloor, which we interpret as volcanic basement. The absence of any discernable arching of the top surface of the guyot is consistent with the lack of any but minor relief on the top of volcanic basement.

We interpret the perimeter rim as an erosional remnant, carved during a time of emergence of the guyot. The relief from the top of the highest parts of the rim to the depressions on the floor of the central part of the guyot is about $60 \mathrm{~m}$, which gives a measure of the amount of limestone removed by erosion prior to final drowning of the guyot. Reflectors that are traceable across the central region lose their coherence beneath the rim, an effect that may be caused by meteoric-water diagenesis of the rim during emergence of the guyot, producing limestone with very high acoustic impedance at the surface.

\section{Horizon Guyot (at DSDP Site 171)}

Survey tracks around Deep Sea Drilling Project (DSDP) Site 171, located in a plateau-like saddle between Horizon Guyot (Ho in Fig. 1B) and an unnamed guyot to the west are fairly close-spaced and allow for the construction of a contour map showing the topography of the top of the Lower Cretaceous shallow-water platform limestone beneath hemipelagic and pelagic sediments of Turonian to Cenozoic age. As shown in the contour map (Fig. 46), the surface is irregular, with local relief of several hundred meters. A steep north-trending escarpment, possibly a fault, separates the region around Site 171 from the main mass of Horizon Guyot. The limestone layers, as shown in seismic reflection profiles (Fig. 47), are nearly flat-lying.

At Site 171, drilling (Shipboard Scientific Party, 1973) documented about $287 \mathrm{~m}$ of Cenozoic and Upper Cretaceous calcareous pelagic sediments, about $43 \mathrm{~m}$ of ashy Turonian-Campanian sandstone and siltstone with redeposited land-plant fragments, and then about $8 \mathrm{~m}$ of undated subaerial basalt overlying $7 \mathrm{~m}$ of breccia of lagoonal limestone and basalt fragments. Below, $134 \mathrm{~m}$ of shallowwater limestone was penetrated, but with poor recovery. A tentative age assignment for the limestone of early Cenomanian was based on one planktonic foraminifer, which might have fallen from farther up the hole. Petrographic study of fragments of the limestone suggested that cementation took place partly under the influence of meteoric waters, during emergence (Shipboard Scientific Party, 1973). The hole bottomed in tholeiitic basalt.

We interpret the erosional unconformity seen on the reflection profile as pre-late Campanian, perhaps formed during an emergence associated with Campanian volcanism in the MPM, which is manifested at DSDP Site 313, about $180 \mathrm{~km}$ northwest of Site 171 (Shipboard Scientific Party, 1975). This episode of volcanism may have 


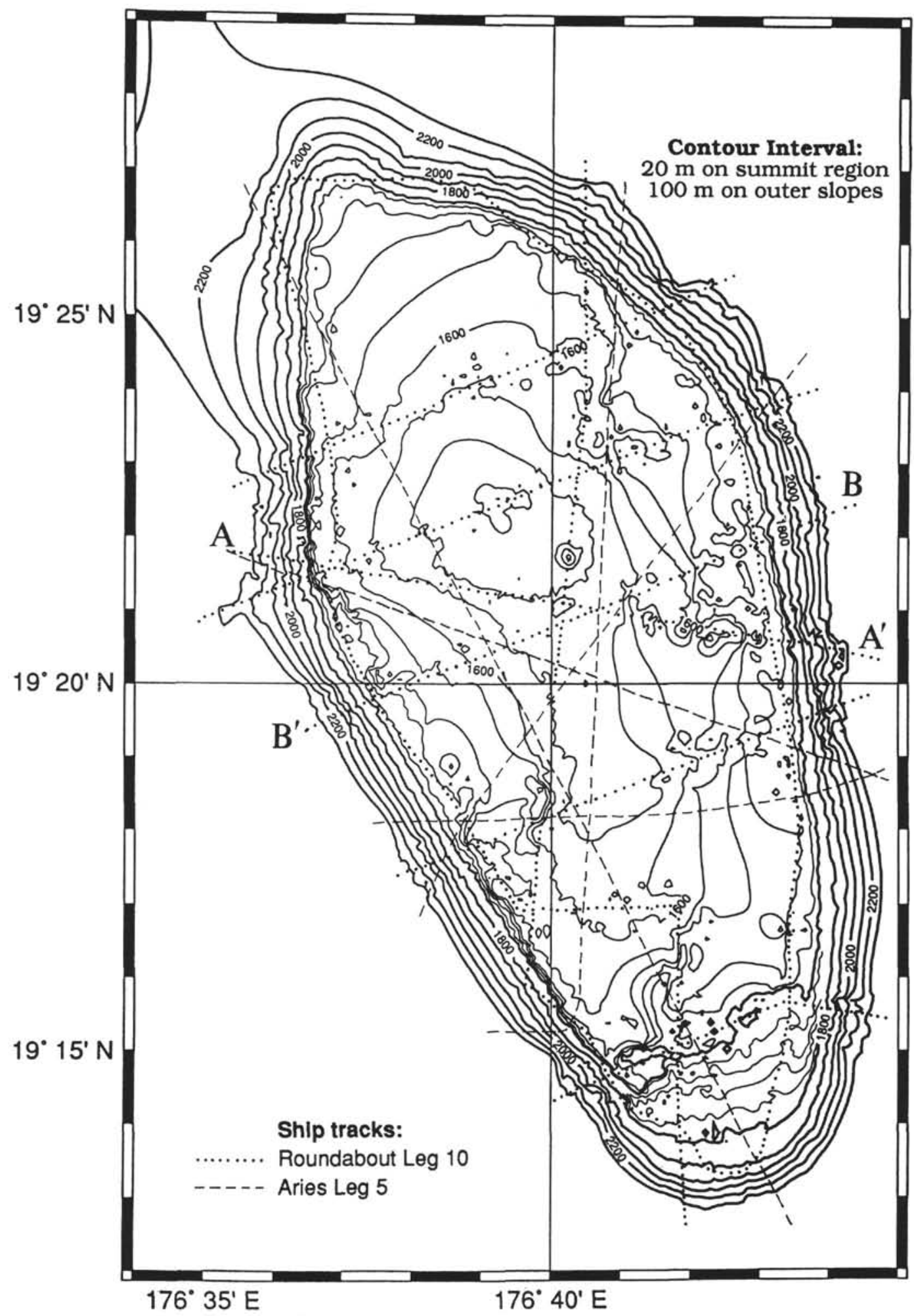

Figure 37. Bathymetry of the summit of Jacqueline Guyot. Tracks of cruise data used are SIO Thomas Washington, Aries, Leg 5 (standard echo-sounder), and Roundabout, Leg 10 (multibeam echo-sounder). 


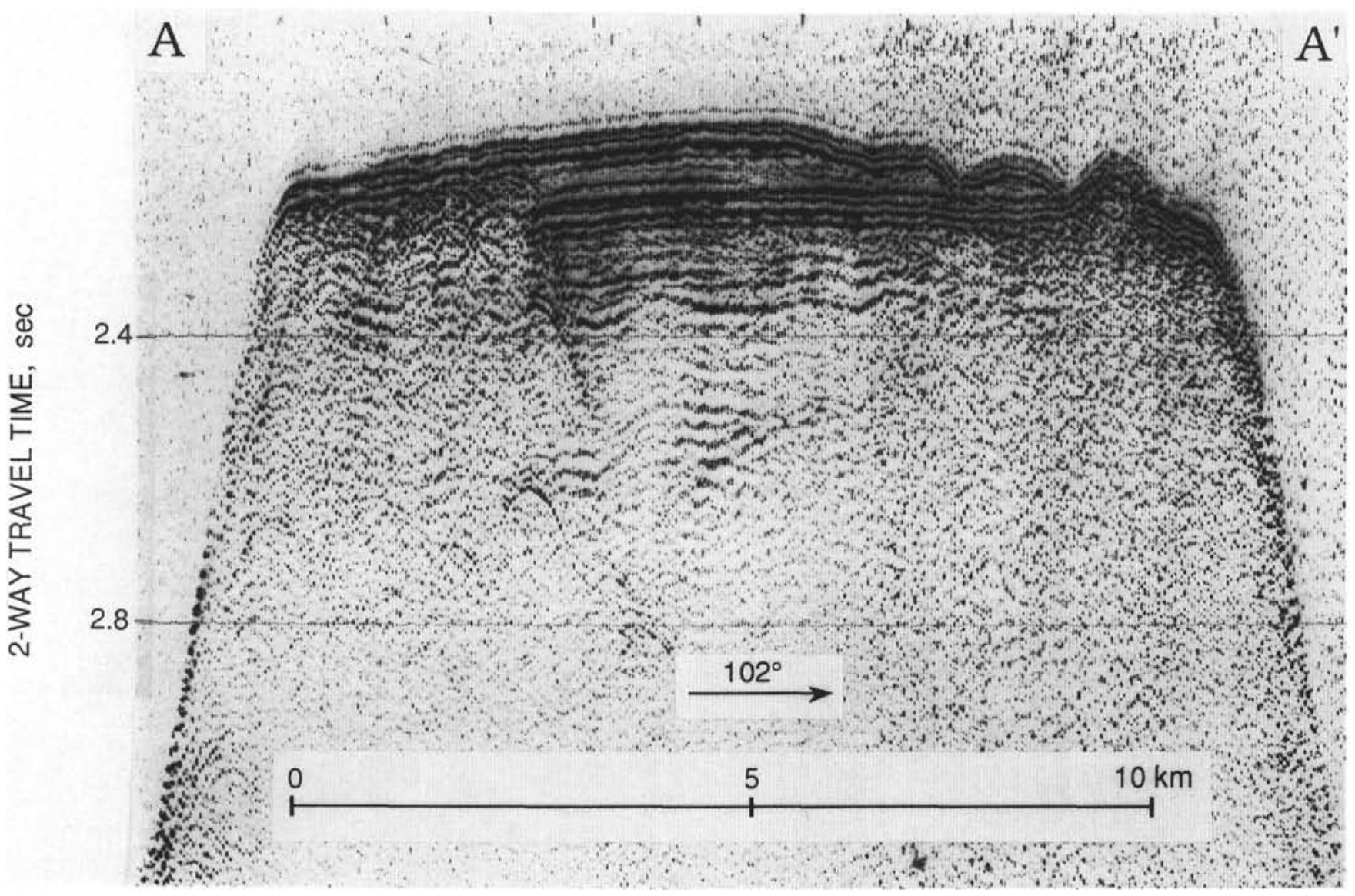

Figure 38. Seismic-reflection profile A-A' across Jacqueline Guyot, showing pelagic sediments covering an irregular surface on the underlying Cretaceous platform limestone. The top of the limestones is at about $2.2 \mathrm{~s}$ TWT on the left (west) side of the guyot, where the pelagic cover is thin $(<0.05 \mathrm{~s}$ TWT). About $2.5 \mathrm{~km}$ from the west side of the guyot, the unconformity slopes steeply down to the east and continues as a smooth, gently arched surface to a point about $2 \mathrm{~km}$ from the right (east) side of the guyot, where the limestone emerges from beneath the cover of pelagic sediments to form a hill. The pelagic cover over the central part of the guyot is about $0.1 \mathrm{~s}$ TWT in thickness. The clarity of reflections within the limestone sequence changes from excellent, beneath where the pelagic cover is thick, to mediocre, where the pelagic cover is thin or absent. Nonetheless, major reflectors within the platform limestone succession can be traced continuously across the guyot, showing that the relief results from erosion, not faulting. We interpret the reflector at about $2.55 \mathrm{~s}$ TWT, beneath the summit, to be the top of volcanic basement. Note that it is shallowest in the center of the guyot and slopes down to the west (left). Profile taken from SIO Thomas Washington, Roundabout, Leg 10. Vertical exaggeration at seafloor about $11 \times$.

begun as early as Turonian time, as evidenced by the Turonian sediments, and plausibly also the subaerial basalt flow and conglomerate at Site 171. We suggest that the faulting between Site 171 and Horizon Guyot dates from that episode.

\section{Sio Guyot}

Sio Guyot, the large guyot at the southwest corner of the MPM (Si in Fig. 1A), was surveyed by Nemoto and Kroenke (1985) (Fig. 48), but reflection data are not sufficiently dense to construct a reliable contour map of the surface of unconformity between Cretaceous platform limestone and overlying pelagic sediments. Instead, we show here a $3.5-\mathrm{kHz}$ profile (Fig. 49) and a seismic-reflection profile (Fig. 50), both taken from JOIDES Resolution during Leg 143, that indicate a highly irregular surface beneath the pelagic sediment cover. The total relief on this surface is at least $225 \mathrm{~m}$. The highest part of the erosion surface consists of a block having nearly vertical side slopes, similar to the high block on "Renard" Guyot (Fig. 43).

We interpret the irregular surface as an erosional surface, carved during an episode of emergence of the guyot to a height of at least 225 $\mathrm{m}$ above sea level. The rocks beneath the unconformity may include both platform limestone and volcanic breccia. Volcanic breccia was dredged by Nemoto and Kroenke (1985) from high on the steep outer slopes of the guyot (Dredge Site RD68 in Fig. 48). A possibly similar unit of volcanic breccia, interbedded in the platform limestones, is also reported from MIT Guyot, about $2200 \mathrm{~km}$ northwest of Sio Guyot (Shipboard Scientific Party, 1993c). At Sio Guyot, the high impedance of reflectors in the upper part of the guyot mask any deep-lying volcanic basement that may be present. Nemoto and Kroenke (1985) interpreted their reflection data as showing a thickness of about $200 \mathrm{~m}$ of limestone above basement on a small guyot adjacent to Sio Guyot.

\section{SYNTHESIS AND CONCLUSIONS}

\section{Arching of Upper Surface of Platform Limestone Strata}

Seismic-reflection data for MPM guyots show that remnant relief on the volcanic basement beneath the capping platform limestone tends to be reflected in a subdued form in the topography of the upper surface of the limestone cap. This form is commonly a broad dome or arch. Because the platform limestone strata were deposited very close to sea level, judging by drilling results on Allison and Resolution guyots (Shipboard Scientific Party, 1993a, 1993b, 1993c), the warped form of the upper limestone strata must have developed after cessation of platform construction. 


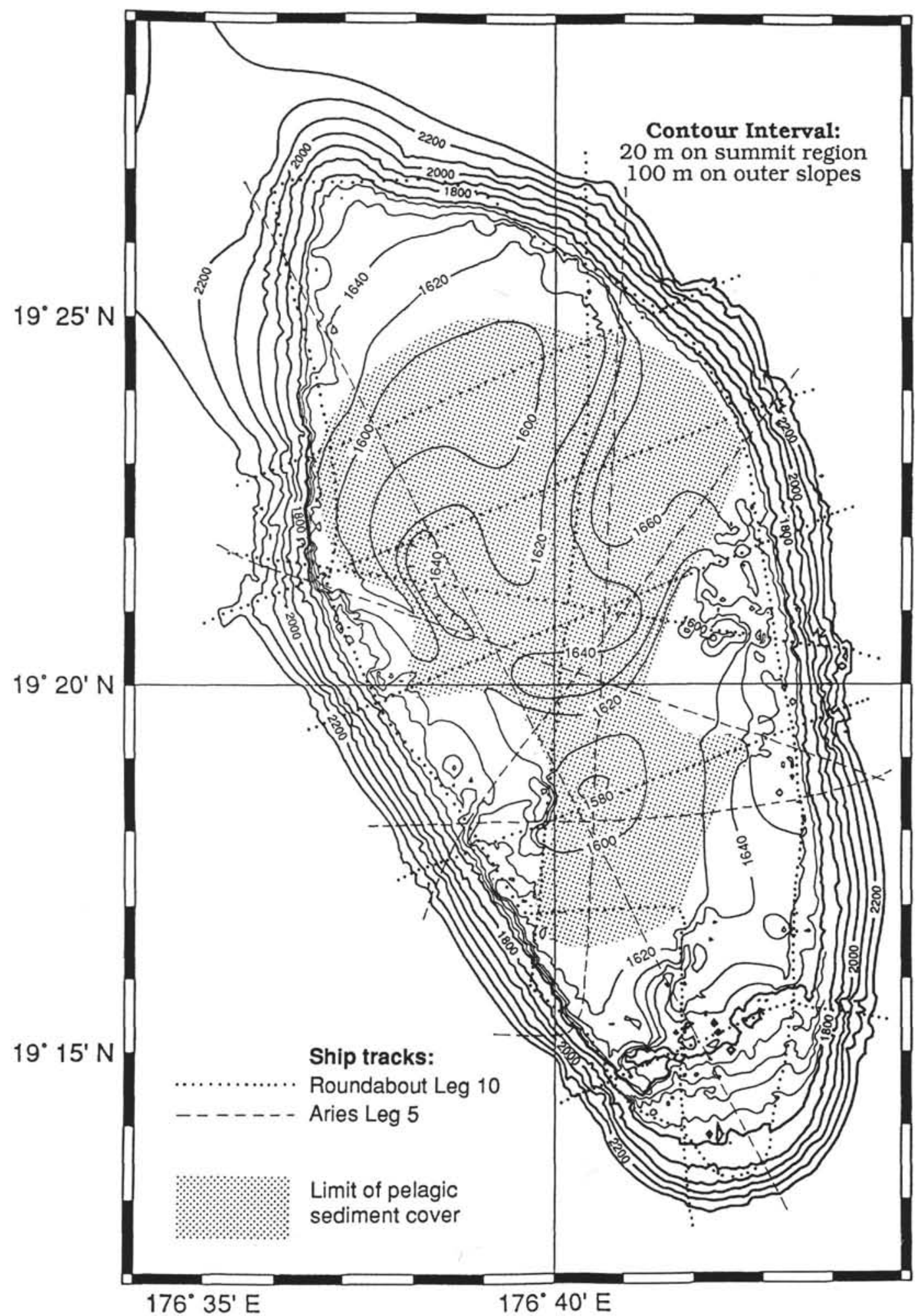

Figure 39. Contour map showing the top of Cretaceous platform limestone beneath the cover of pelagic sediments on Jacqueline Guyot. Note the small canyons and the partial perimeter rim at the south end of the guyot. The slopes around the reentrant in the central part of the guyot may be steeper than shown here: the reflection profiling system cannot resolve slopes steeper than about $20^{\circ}$. 


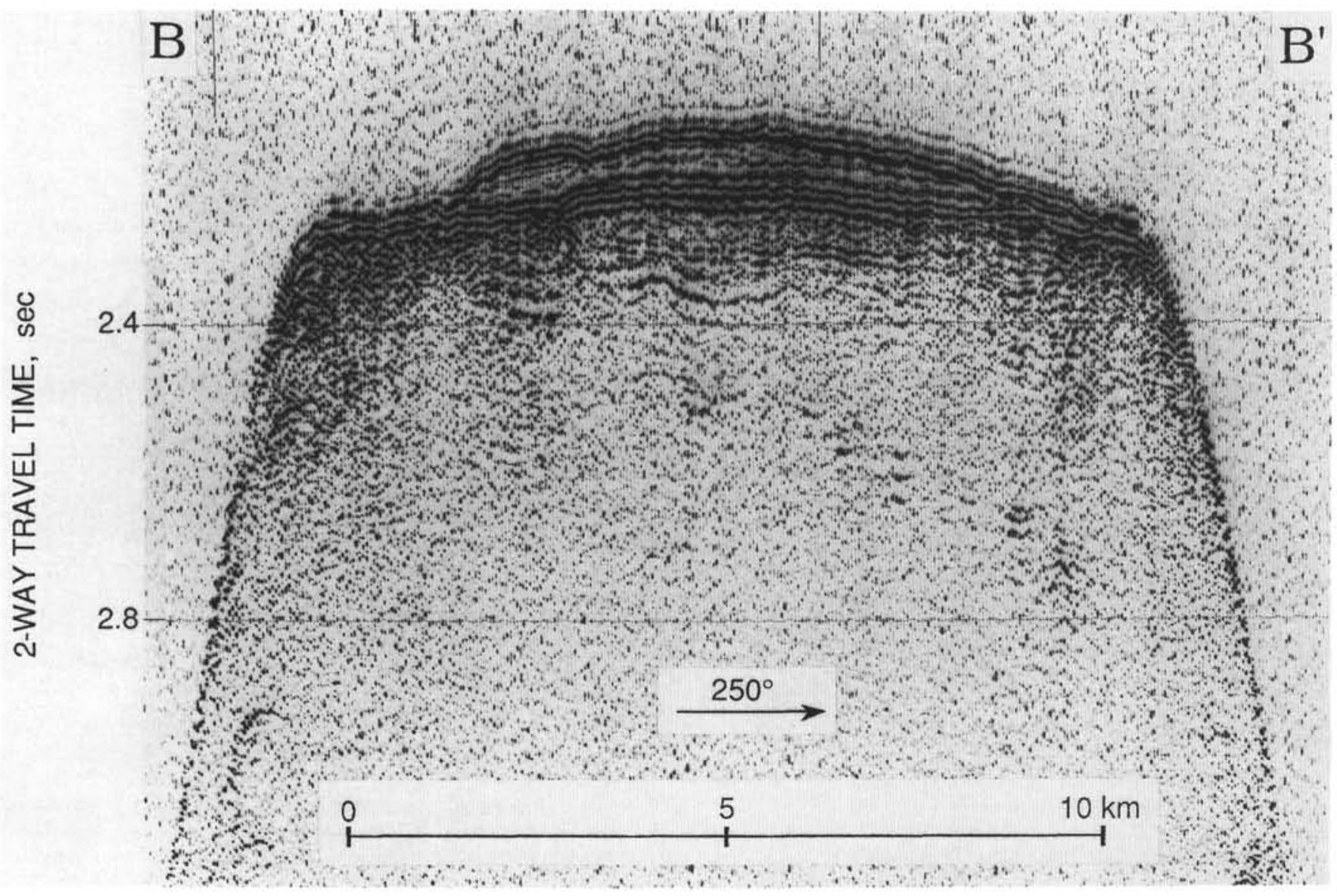

Figure 40. Seismic-reflection profile B-B' across Jacqueline Guyot, showing the reflector interpreted as the top of volcanic basement at about $2.55 \mathrm{~s}$ TWT under the center of the guyot. From there, the reflector slopes away to the west (right). Note that the clarity of reflectors in the platform limestone succession deteriorates as the pelagic sediment cover becomes thinner. Where pelagic sediments are absent, as at the left (east) end of the profile, no coherent reflectors can be discerned beneath the seafloor. Profile taken from SIO Thomas Washington, Roundabout, Leg 10. Vertical exaggeration at seafloor about 13x.

On some guyots, where the seismic data are clear, as for example, on Allison Guyot, the lower beds in the platform sequence onlap the remnant relief on the volcanics, with the result that the thickness of limestone is less over volcanic hills than over valleys or side slopes. Further, the dips of older limestone layers are commonly less than dips in overlying layers (Fig. 2). We interpret these relations as supporting differential compaction of the limestone as the prime cause of the relief on the upper limestone surface. A thicker section, other factors being equal, will compact more than a thinner section.

An important additional cause of differential compaction is the presence of clayey layers interbedded in the limestone, which the drilling on Allison Guyot showed to be abundant in the lower part of the section, deposited when some remnant volcanic relief was still supplying detritus to its surroundings. There doubtless remained at least modest remnant relief on virtually every guyot at the time of inception of sedimentation on the eroded volcanic basement, though on some guyots, for example, on "Heezen" Guyot, the relief was small, and consequently the effects of differential compaction were small-although still visible in the seismic records.

Compaction of onlapping layers against a buried hill will produce a supratenuous fold in the upper layers. In beds of uniform lithology, compaction is a function of overburden, and the greater thickness of beds away from the hill results in compaction that deforms the originally flat layers to conform with the shape of the underlying uncompactable hill. Inspection of the contour maps and seismic profiles of Allison, Resolution, and Jacqueline guyots, where adequate seismic control is available, shows that the upper surface of the platform limestone conforms fairly well with what can be inferred about the underlying volcanic basement topography. Added to this purely geometrical effect, there may also be lithologic differences in strata, for example, more clayey or marly layers in the lower part of the sequence, deposited while the hill was still not completely buried. These strata may be more compactable than clay-free limestone layers deposited after burial of the volcanic hill.

Compaction will proceed apace with deposition, and lower layers continue to compact (ever more slowly) as new layers are added to the top of the stack. The compactional response to loading, especially in limestone, is not instantaneous because of the complex processes of intrastratal dissolution and recrystallization that must take place to compact limestone. Thus, compaction continues even after deposition of the last layer of limestone. Given that the final layer of platform limestone was essentially flat and at sea level, all the relief that we see today on the unconformity between platform limestone and pelagic sediments was developed after cessation of limestone deposition.

\section{The Emergence Hypothesis}

\section{Conclusions from Lithologic, Petrographic, and Geochemical Studies}

Lithologic, petrographic, and isotopic data indicate the presence of interconnected dissolution cavities that extend down into the Albian limestone strata on Allison and Resolution guyots to depths of as much as $100 \mathrm{~m}$, into which pelagic sediments trickled after the guyot drowned. The diagenetic history of the upper few hundred meters of 


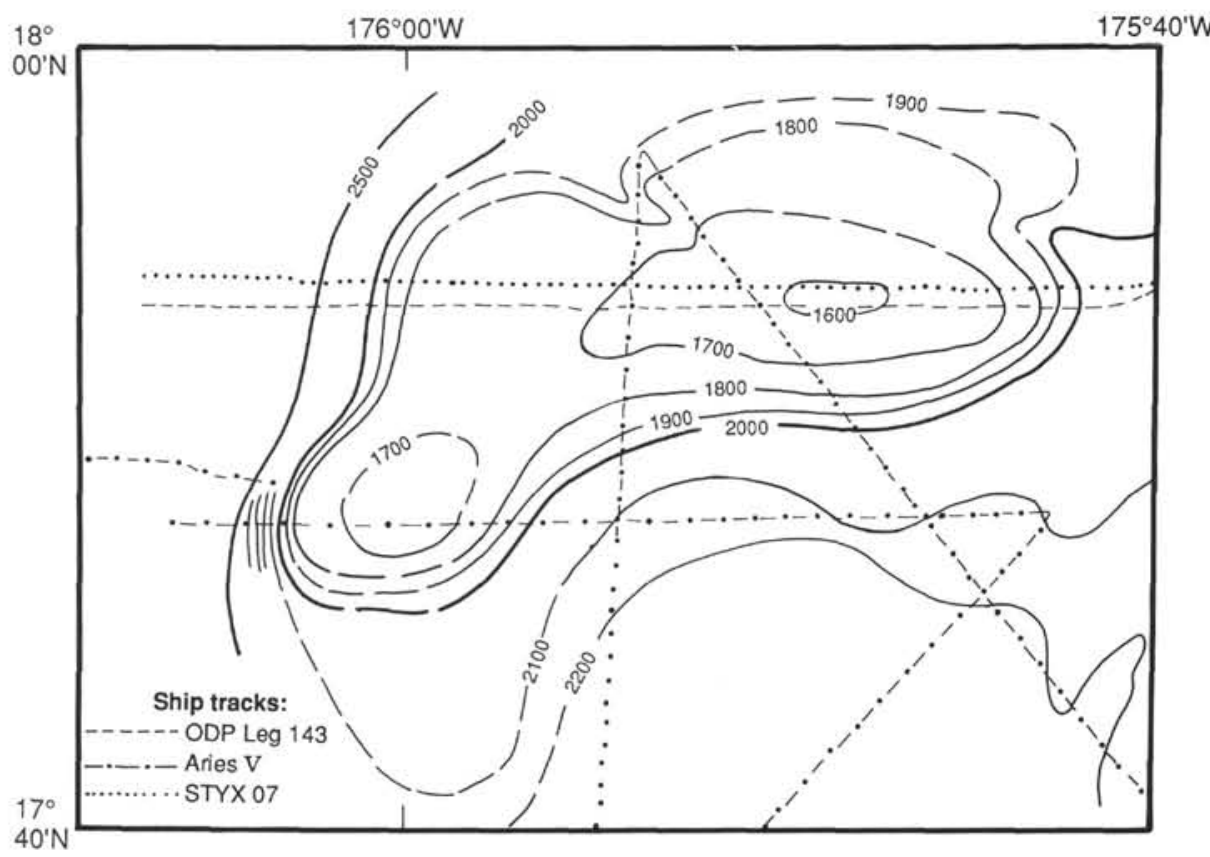

Figure 41. Bathymetry of Renard Guyot. Contour interval, $100 \mathrm{~m}$. Tracks of cruises with precision echo-soundings shown.

Albian-age shallow-water limestones on Allison and Resolution guyots included several stages of dissolution, cementation, and infilling of secondary pore space with internal sediments. Textural relationships indicate that most of the secondary porosity formed when the platform was still at or very close to sea level, early in the history of these sediments. The first materials to fill these pores were of shallow-water origin, but an open-pore textures persisted, resulting in the infiltration of younger (Upper Cretaceous) pelagic sediments to depths of several tens of meters into the shallow-water section at later stages. In many places, a second episode of dissolution can be inferred from the co-occurrence of moldic pores that are filled with crystalline calcite cements, of enhanced moldic pores, and even of nonfabric-selective vugs that remain unfilled by crystalline cements.

Most of the large secondary pores and cavities can be attributed to dissolution of large aragonitic shell fragments, especially rudists. Intervals that contain many such large shells, such as those at Sites 867 and 868 , contain more cavities. The occurrence of planar cavities, especially in the platform-interior facies at Site 865, suggests that material may have been removed along bedding planes, perhaps as the result of dissolution of evaporitic deposits.

Stable isotopic analyses show little distinction between the uppermost parts of the limestone successions and those below. Most of the isotopic values can be interpreted as progressive diagenesis from warm surface waters to cooler, deeper waters. Most of the coarse, crystalline cements that line and fill some of the secondary pore spaces formed late in the diagenetic history of the sediments, probably in cooler waters.

A single interval, $23 \mathrm{~m}$ below the top of Site 867 , shows textural and geochemical evidence of diagenesis in a vadose zone. This suggests that an episode of exposure of the summit of Resolution Guyot did occur, but that it left only sparse evidence in the rocks. Apparently, the main effect of exposure was dissolution of limestone. Possibly, meteoric-water diagenesis occurred preferentially along discrete pathways within the porous rocks, and left little evidence in the recovered core samples. Other atolls having evidence of emergence also show no evidence of meteoric-water effects in the isotopic composition of the limestones (e.g., Aissaoui, 1988).

\section{Conclusions from Morphologic Data}

The morphologic data are much less equivocal in indicating an episode of emergence of the guyots prior to final subsidence. Evidence of erosion of the upper parts of the platform limestone is evident at all the guyots described above. On some guyots (e.g., Allison), there is evidence of an old surface drainage system; on others (e.g., Resolution) the erosional forms include sinkholes and remnant pinnacles; and on some others (e.g., "Renard" and "Jacqueline"), lines of steep cliffs are at the back of a sloping bench. On several of the guyots, a partial to complete perimeter was formed by an erosional ridge bordered on the inside by a chain of moat-like depressions.

The local erosional relief visible in profiler records of guyots in the MPM ranges from about $60 \mathrm{~m}$ at "Heezen" Guyot to about $200 \mathrm{~m}$ at Allison Guyot, to perhaps $300 \mathrm{~m}$ near DSDP Site 171 at Horizon Guyot. An unknown thickness of limestone overlying the highest platform limestone beds was removed by erosion.

The seismic evidence (e.g., from Allison Guyot, Fig. 8) supports an erosional origin for the ridge-moat pair in showing that reflectors in the perimeter rim are truncated at the moat. Such evidence is not everywhere clearly seen because reflectors within the rim ridge are generally nearly to completely obscured by the effects of the high impedance of the seafloor close to the perimeter. Pelagic sediments are virtually absent around the edges of the platform, which is open to sweeping by oceanic currents. At Resolution Guyot, both dredging and drilling (van Waasbergen and Winterer, 1993; Shipboard Scientific Party, 1993c) show that a dense crust of phosphorite and ferromanganese oxides caps the platform limestone around the perimeter. Bottom photographs taken during the transit across the perimeter terrace at Resolution Guyot from Sites 867 to 868 show a pavement of phosphorite and ferromanganese oxides that is broken into large slabs a few meters across, some of which are tilted at angles to the horizontal (Shipboard Scientific Party, 1993c). The combination of high impedance contrast between water and the pavement on the one hand, and the roughness of the pavement on the other, gives rise to a strong seismic reflector with many corner reflections that create hyperbolic traces in the record and mask and interfere with reflections from buried reflectors. 

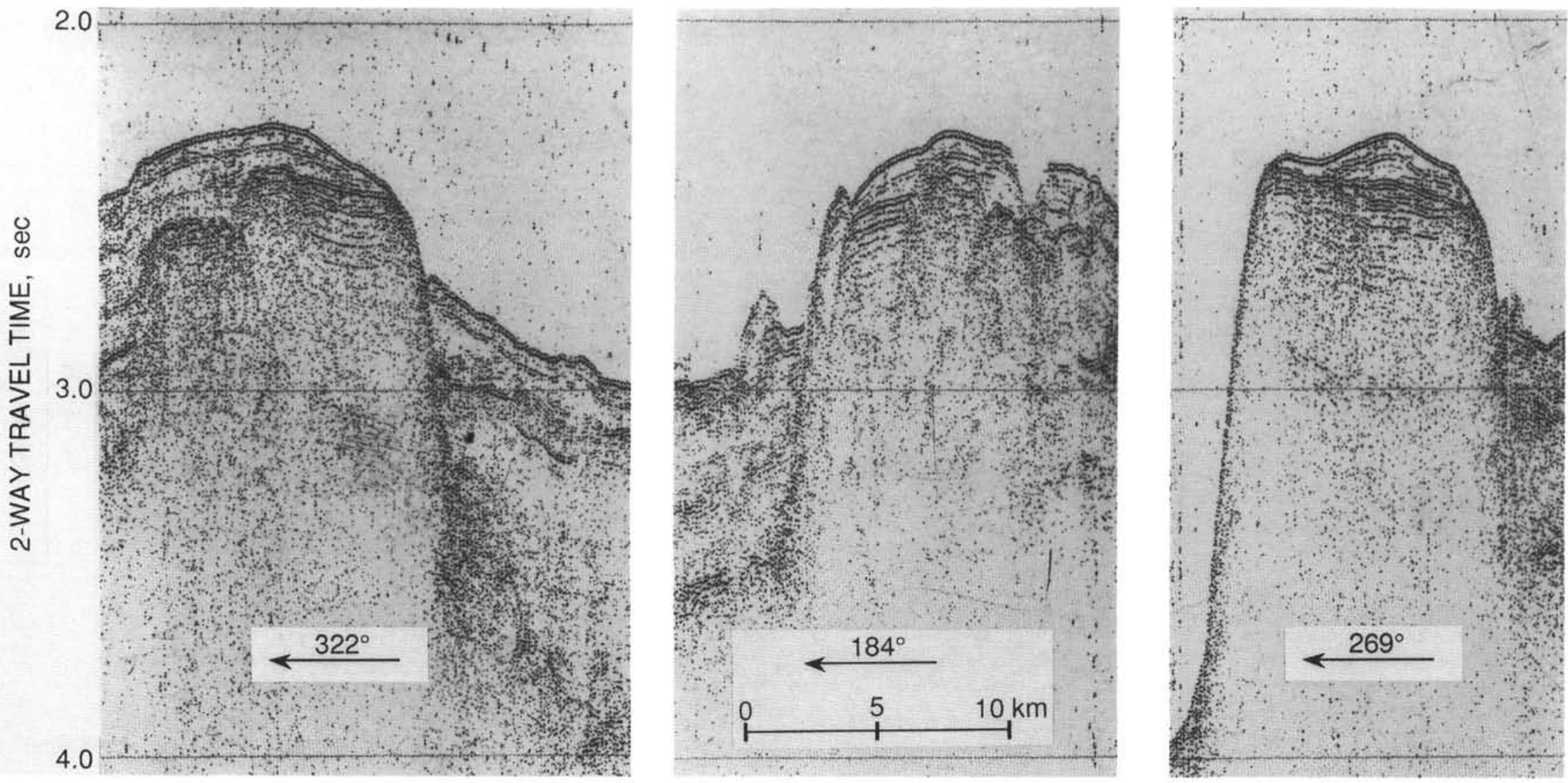

Figure 42. Seismic-reflection profiles across Renard Guyot, showing (left and center panels) the buried escarpments of Cretaceous limestone on the eastern arm of the guyot. Note the outward dip of reflectors in the limestone. Volcanic basement is interpreted to be at about 3.0 to $3.1 \mathrm{~s}$ TWT beneath the guyot. The profile across the southern arm (right panel) shows the east dip of Cretaceous limestone layers. The reflection representing the top of volcanic basement is interpreted to be at about $3.0 \mathrm{~s}$ TWT. Note the steepening of this reflector westward, toward the west edge of the guyot. We suggest that the western part of this sector of the guyot was carried away by mass wasting, leaving only the east part. Using an average sound velocity of $3 \mathrm{~km} / \mathrm{s}$, as determined from drilling at Site 865 on nearby Allison Guyot (Shipboard Scientific Party, 1993a), the limestone section is estimated to be about $900 \mathrm{~m}$ thick. Profiles taken from SIO Thomas Washington (Aries, Leg 5). The left panel shows the entirety of the northwest-directed Aries, Leg 5 track; the center panel, the entirety of the south-directed track; and the right panel, the western two-thirds of the west-directed track. Vertical exaggeration at seafloor about $17 \times$. 


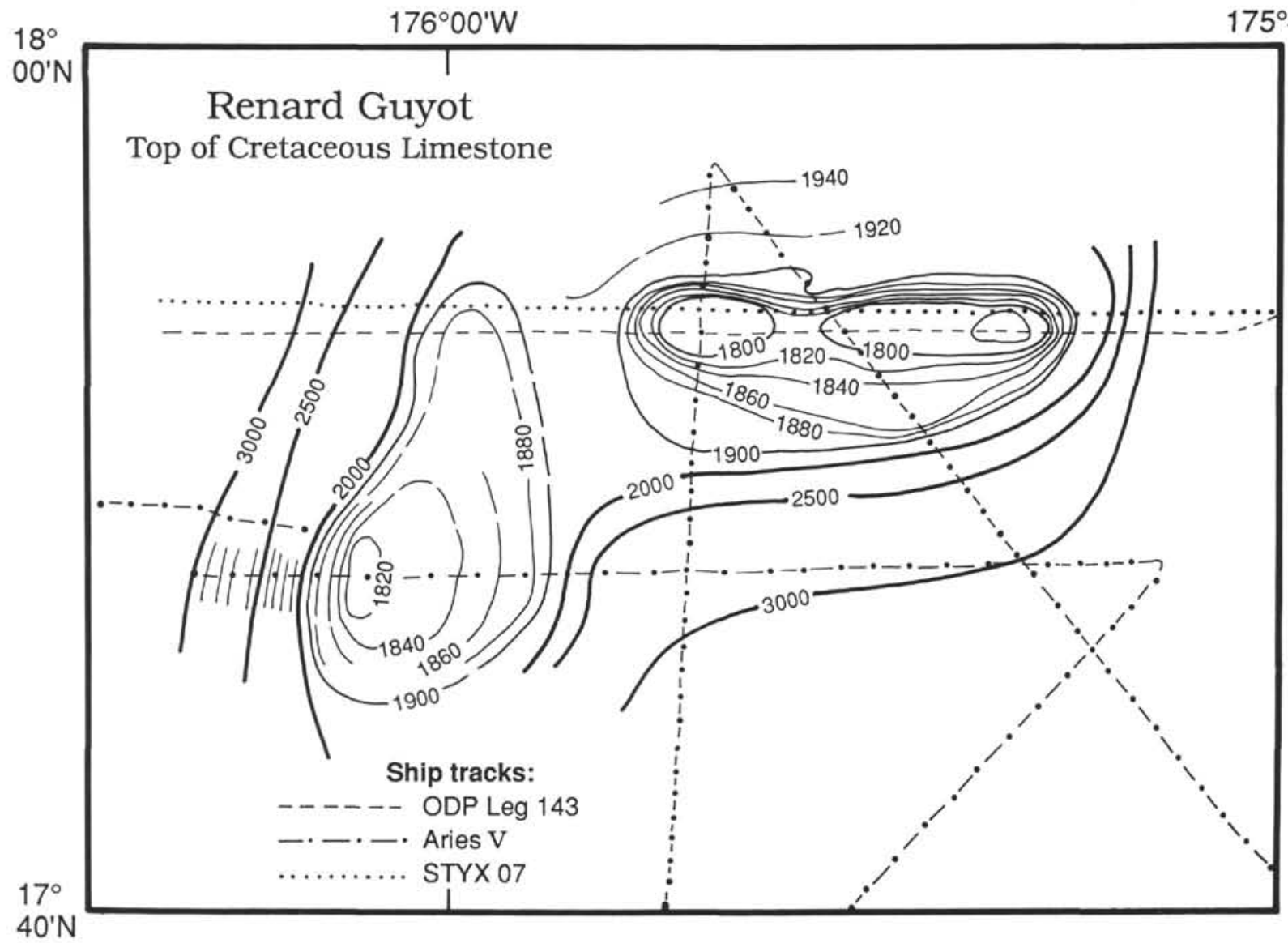

Figure 43. Contour map of the unconformity between pelagic sediments and the underlying Cretaceous platform limestone (summit area). Below the summit area, the contours depict the limestone and volcanic slopes beneath any pelagic cover. Contour interval, $20 \mathrm{~m}$ over the summit region of the guyot, with 100- and 500-m contours on the steep slopes below. From seismic-reflection data collected from SIO Thomas Washington during Roundabout expedition, Leg 10, and from JOIDES Resolution during Leg 143.

Pelagic sediments overlie and seal the erosional surface, and thus, the episode of erosion pre-dates the oldest pelagic sediments. Drilling data from Allison Guyot (Shipboard Scientific Party, 1993a) show pelagic sediments as old as middle Turonian in cavities of upper Albian platform limestone. At Site 865, the oldest pelagic sediments drilled on the platform limestone are Paleocene in age. The maximum time available between cessation of platform limestone accumulation and deposition of pelagic sediments on the drowned and eroded platform thus is about 9 m.y., mainly during the Cenomanian, but it could, of course, have been a much shorter time. Farther west, at MIT Guyot, a manganese nodule containing fossils of latest Albian age is embedded in pelagic sediments that rest directly on shallow-water platform limestone of late Albian age (Shipboard Scientific Party, 1993d).

Two plausible hypotheses for the origin of the erosional topography present themselves:

1. The erosion took place in the submarine environment, during subsidence of the guyot from sea level to the depths at which pelagic sediments permanently accumulated.

The present depth to the top of the limestone at the MPM guyots ranges from about $1300 \mathrm{~m}$ (Resolution) to $2400 \mathrm{~m}$ (Horizon, Site 171 area), and we assume the subsidence history, especially in the first 10 m.y., did not carry the guyots significantly deeper than their present depths. Subsidence rates, as estimated from the thickness of Albian and Aptian limestone strata deposited prior to drowning, was about $60 \mathrm{~m} / \mathrm{m}$.y. at Allison and about $30 \mathrm{~m} / \mathrm{m}$.y. at Resolution, and subsi- dence rates would have suddenly to have increased by a factor of roughly two to four times to carry guyots into water as much as 1000 $\mathrm{m}$ deep after 10 m.y. We postulate that this amount of increase is unlikely. To develop the deep, closed, sinkhole-like depressions required dissolution of limestone, and we consider this to be unlikely at such shallow depths. Good preservation of Albian-Turonian planktonic foraminifers can be seen in pelagic carbonate sediments deposited about $1600 \mathrm{~m}$ deeper than the summit of Resolution Guyot, in the adjacent basin, at DSDP Site 463 (Fig. 18) (Thiede et al., 1981), indicating that significant dissolution at the summit of the guyot would be extremely unlikely during this time interval.

Erosional forms also include a surface drainage pattern of valleys on Allison Guyot and sinuous lines of steep erosional slopes above formerly flat benches on Jacqueline, Renard, and, perhaps, Sio guyots. We cannot think of simple ways to produce such forms in the submarine environment. The gradients of the valleys on Allison Guyot are too flat for them to have been carved as submarine canyons by turbidity currents, and the small area of the summit would likely be inadequate to supply turbid water for such currents.

2. The erosion took place during an episode of emergence of the guyot summits above sea level, following which the guyots sank below sea level. This was prior to much of the arching of the guyot surface by differential compaction.

In this hypothesis, the valleys on Allison Guyot are subaerial stream courses, the closed depressions are karstic sinkholes, and the 


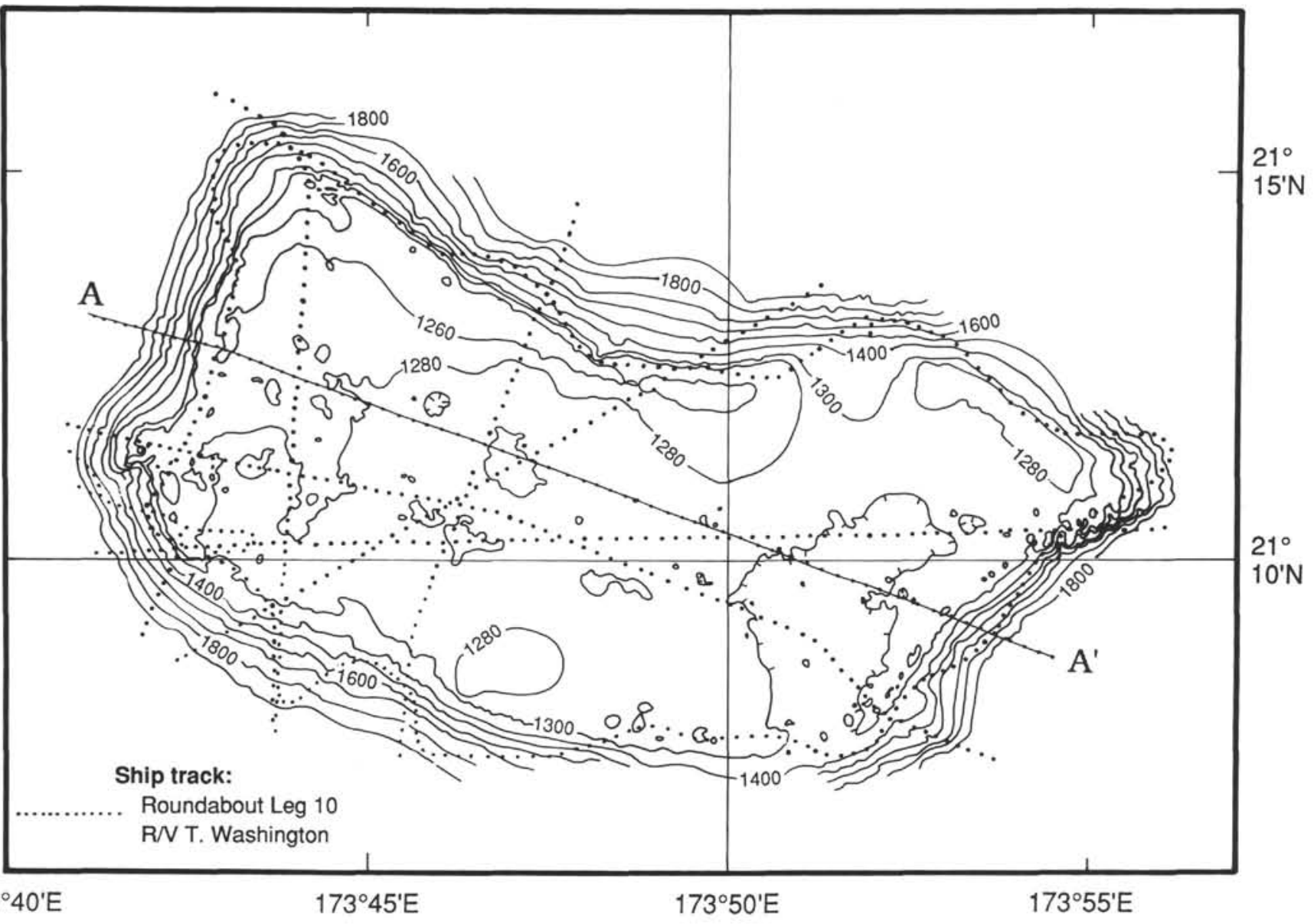

Figure 44. Bathymetric map of summit region of "Heezen" Guyot, using multibeam data collected from Thomas Washington during SIO Roundabout expedition, Leg 10. Contour interval, $20 \mathrm{~m}$ on top surface of guyot, $100 \mathrm{~m}$ on upper slopes. Note perimeter rim, which is highest along the northwest part of the guyot. Line $\mathrm{A}-\mathrm{A}^{\prime}$ shows the location of the seismic profile shown in Figure 45.

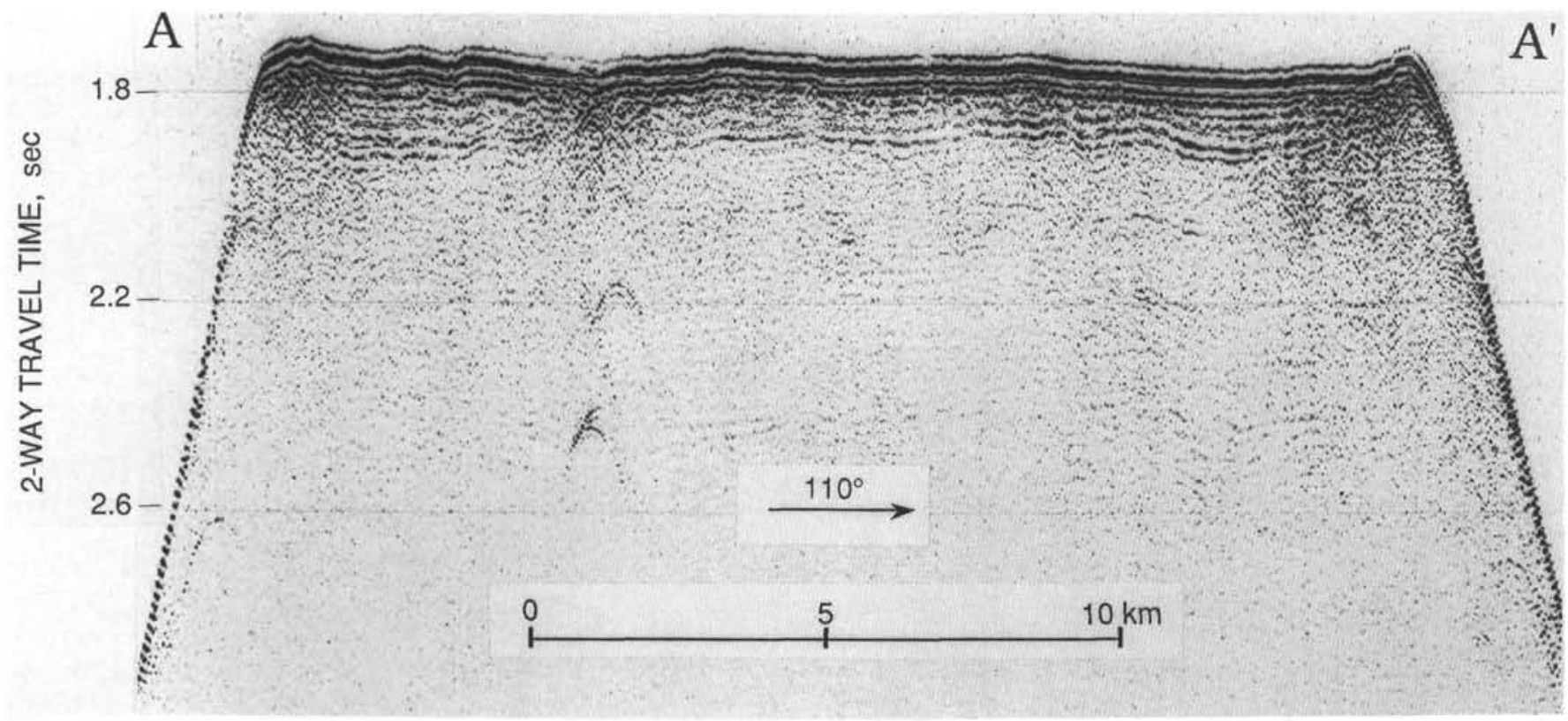

Figure 45. Seismic-reflection profile (A-A' in Fig. 44) across "Heezen" Guyot. The reflector at about $0.7 \mathrm{~s}$ TWT beneath the seafloor (bsf) is the deepest coherent reflector, and may be either the top of volcanic basement or may correlate with the strong reflector at 1200 mbsf at Site 866 on Resolution Guyot, about $50 \mathrm{~km}$ west of "Heezen" Guyot. At Site 866, a similar reflector marks the contact between Barremian limestones and dolomites (Shipboard Scientific Party, 1993b). Because the first multiples of reflectors on this profile do not appear until about $3.5 \mathrm{~s}$ total TWT, we regard the reflectors between the seafloor and $0.7 \mathrm{~s}$ bsf as coming from real interfaces, except for the reflector at about $0.3 \mathrm{~s}$ bsf, which is probably an internal multiple. Profile taken from Thomas Washington during SIO Roundabout expedition, Leg 10 . Vertical exaggeration at seafloor about $12 \times$. 


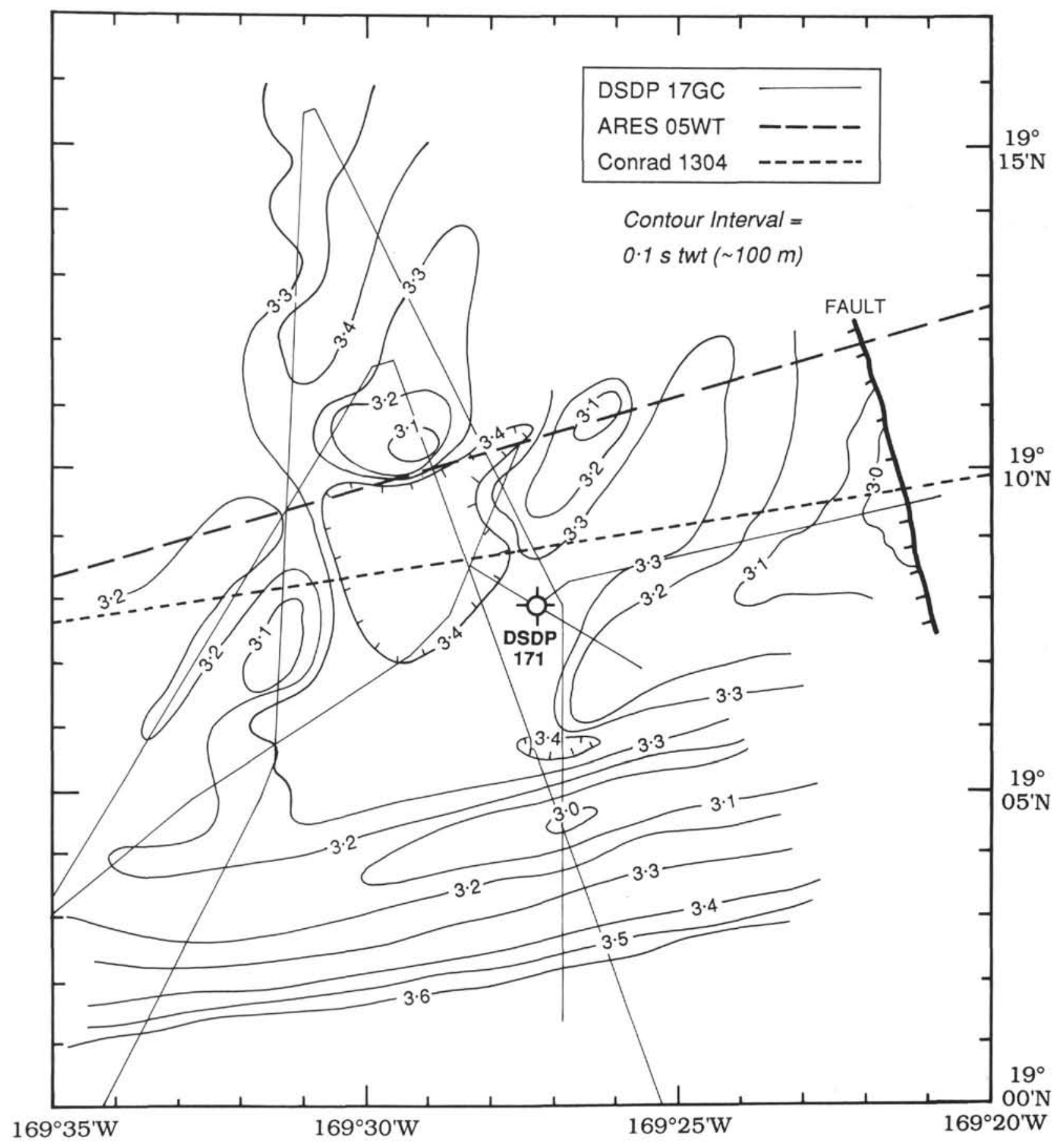

Figure 46. Contour map of the unconformity at the base of the pelagic sediments in the region around DSDP Site 171, in the saddle immediately southwest of Horizon Guyot. The tracks of seismic lines used as control are shown. We have poor information on the actual velocities for the pelagic sediments in this area, so have contoured in two-way traveltime. The heavy dashed line shows the location of the seismic profile in Figure 47.

flats below the steep bluffs are wave-cut benches. The perimeter rim may find its explanation in the experimental and observational data of Purdy (1974). He suggested that subaerial dissolution of limestone in a rainy climate is inhibited in places where slopes are steep and the dissolving waters can run quickly off the limestone surface. Thus, when there is a relative fall of sea level around a flat platform, meteoric waters drain directly and quickly seaward from the steep platform edge, which thus escapes significant dissolution. By contrast, waters falling on the flat interior have a longer residence time on the platform and thus can react to dissolve limestone. The integrated result of this process on a flat platform is a drainage divide, or rim, around the perimeter. The emergent carbonate platform of Makatea in the Tuamotu Archipelago is a modern example of an atollshaped island having a perimeter ridge carved by subaerial erosion from Miocene platform limestone during several episodes of emergence (Montaggioni, 1985). Uplifted Miocene platform limestones on a number islands in the Lau Group, in the Southwest Pacific, have atoll shapes, with a high rim around a central depression. As described 


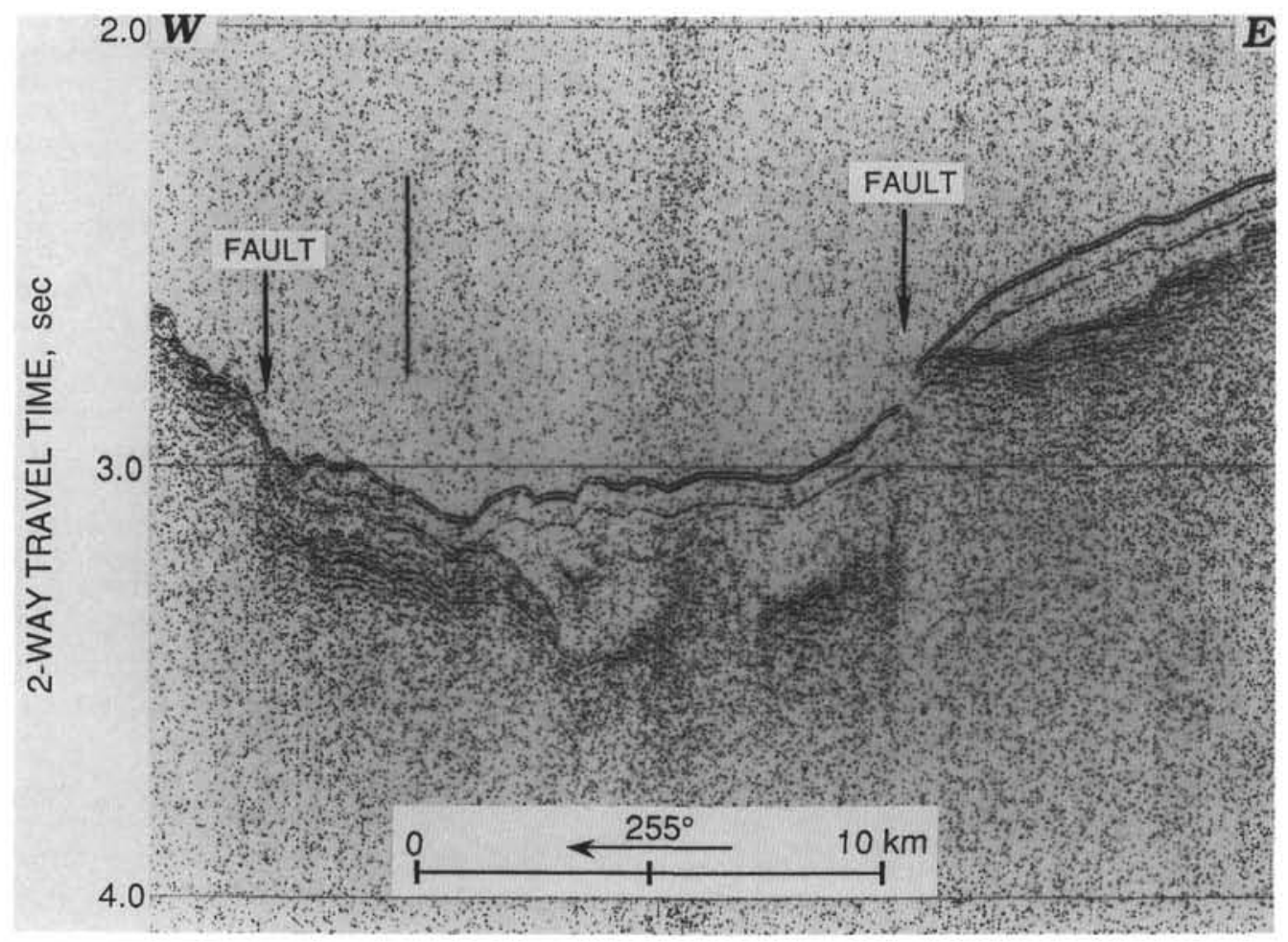

Figure 47. Seismic-reflection profile along Aries, Leg 5, line in Figure 46, showing relief on the unconformity between pelagic sediments and underlying, gently-dipping, mid-Cretaceous limestone and basalt. We interpret the steep offsets on the profile as faults bounding a graben. Profile taken from Thomas Washington during Aries cruise, Leg 5 . Vertical exaggeration at seafloor about $13 \times$.

by Ladd and Hoffmeister (1945), the atoll-like forms are entirely erosional, being carved mainly out of platform-interior strata lacking in framework corals and algae. A particularly graphic example of such a rimmed, high island is the island of Tuvutha in the Lau Group, described by Rodda (1981), whose report includes a detailed topographic map. The uplifted upper Miocene platform limestone strata are riddled by caves and eroded into pinnacle topography by subaerial dissolution of the limestone

The evidence favors the subaerial hypothesis, but this alternative is not without its problems. One problem is the apparent lack of postAlbian shallow-water carbonates on any of the MPM guyots so far sampled. The paleolatitude of Allison guyot was about $15^{\circ} \mathrm{S}$ at the time of emergence near the end of the Albian (Shipboard Scientific Party, 1993a), and the Pacific Plate was probably moving north-northwest, toward the equator at about $52 \mathrm{~km} / \mathrm{m}$.y. during the Cenomanian and Turonian (Pringle, 1993). Why conditions for carbonate platform initiation and growth were unfavorable at this time, not only here but elsewhere in the Pacific and Caribbean, is a matter of speculation. For a discussion of various hypotheses for this dearth of carbonates, as well as a discussion of the possible causes of regional emergence, see the synthesis chapter by Winterer and Sager (this volume).

A result of this episode of emergence and subsequent drowning without renewed platform growth, is that the MPM guyots, as well as a number of Lower Cretaceous guyots elsewhere in the northwest Pacific (van Waasbergen and Winterer, 1993), preserve in their morphology the erosional forms produced during emergence, including in some places, an erosional perimeter ridge. The guyots thus may provide us with examples of potential atolls that never went beyond the stage of creation of the ring-like substrate. As Purdy (1974) and Purdy and Bertram (1993) have suggested, an elevated ring-like substrate, produced by karstic erosion during Neogene glacially controlled fall of sea level, is then colonized by reef-building organisms during sea-level rise, and these grow upward apace with rising sea level, while the adjacent inner and lower parts of the platform cannot catch up with the perimeter rim in rate of upward growth. The result is an atoll. The Early Cretaceous guyots in the northwest Pacific were never atolls, but only proto-atolls.

\section{ACKNOWLEDGMENTS}

We thank the U.S. Science Advisory Committee of the Joint Oceanographic Institutions, Inc., for financial assistance when preparing the manuscript, and Ms Jo Griffith for drafting many of the figures. We are indebted to $\mathrm{C}$. Charles for assistance in running samples in the SIO stable-isotope laboratory. The manuscript was greatly improved by the constructive reviews by E. Purdy, R. Moberly, and W. Sager.

\section{REFERENCES}

Assaoui, D.M., 1988. Magnesian calcite cements and their diagenesis, dissolution and dolomitization, Mururoa Atoll. Sedimentology, 35:821-841.

Daly, R.A., 1934. The Changing World of the Ice Age: New Haven (Yale), 211-261.

Darwin, C., 1842. The Structure and Distribution of Coral Reefs: London (John Murray).

Esteban, M., and Klappa, C.F., 1983. Subaerial exposure environment. In Scholle, P.A., Bebout, D.G., and Moore, C.H. (Eds.), Carbonate Depositional Environments. AAPG Mem., 33:1-54.

Heezen, B.C., Matthews, J.L., Catalano, R., Natland, J., Coogan, A., Tharp, M., and Rawson, M., 1973. Western Pacific guyots. In Heezen, B.C., MacGregor, I.D., et al., Init. Repts. DSDP, 20: Washington (U.S. Govt. Printing Office), 653-723.

Hoffmeister, J.E., and Ladd, H.S., 1944. The antecedent platform theory. $J$. Geol., 52:388-402.

Kuenen, P.H., 1950. Marine Geology: New York (Wiley).

\footnotetext{
Abbreviations for names of organizations and publications in ODP reference lists follow the style given in Chemical Abstracts Service Source Index (published by American Chemical Society).
} 
Ladd, H.S., and Hoffmeister, J.E., 1945. Geology of Lau, Fiji. B.P. Bishop Mus., Honolulu, Bull., 1-181.

Lohmann, K.C., 1988. Geochemical patterns of meteoric diagenetic systems and their application to studies of paleokarst. In James, N.P., and Choquette, P.W. (Eds.), Paleokarst: New York (Springer-Verlag), 58-80.

Montaggioni, L.F., 1985. Makatea island, Tuamotu archipelago. In Delesalle, B., Galzin, R., and Salvat, B. (Eds.), French Polynesian Coral Reefs. 5th Internat. Coral Reef Congr., 1:103-158.

Nemoto, K., and Kroenke, L.W., 1985. Sio guyot: a complex volcanic edifice in the western Mid-Pacific Mountains. Geo-Mar. Lett., 5:83-89.

Pringle, M.S.,1993. Age progressive volcanism in the Musicians seamounts: a test of the hot-spot hypothesis for the Late Cretaceous Pacific. In Pringle, M.S., Sager, W.W., Sliter, W.V., and Stein, S. (Eds.), The Mesozoic Pacific: Geology, Tectonics, and Volcanism. Am. Geophys. Union, Geophys. Monogr. Ser., 77:187-215.

Purdy, E.G., 1974. Reef configurations: cause and effect. In Laporte, L.F. (Ed.), Reefs in Time and Space. Spec. Pub.-Soc. Econ. Paleontol. Mineral., 18:9-76.

Purdy, E.G., and Bertram, G.T., 1993. Carbonate concepts from the Maldives, Indian Ocean. AAPG Stud. Geol., 34.

Rodda, P., 1981. The phosphate deposits and geology of Tuvutha. Econ. Invest.-Fiji, Miner, Resour. Dep., 3:1-43.

Shinn, E.A., and Robbin, D.M., 1983. Mechanical and chemical compaction in fine-grained shallow-water limestones. J. Sediment. Petrol., 53:595618.

Shipboard Scientific Party, 1973. Site 171. In Winterer, E.L., Ewing, J.I., et al., Init. Repts. DSDP, 17: Washington (U.S. Govt. Printing Office), 283-334.

, 1975. Site 313: Mid-Pacific Mountains. In Larson, R.L., Moberly, R., et al., Init. Repts. DSDP, 32: Washington (U.S. Govt. Printing Office), 313-390.
1981. Site 463: western Mid-Pacific Mountains. In Thiede, J., Vallier, T.L., et al., Init. Repts. DSDP, 62: Washington (U.S. Govt. Printing Office), 33-156.

, 1993a. Site 865. In Sager, W.W., Winterer, E.L., Firth, J.V., et al., Proc. ODP, Init. Repts., 143: College Station, TX (Ocean Drilling Program), 111-180.

, 1993b. Site 866. In Sager, W.W., Winterer, E.L., Firth, J.V., et al., Proc. ODP, Init. Repts., 143: College Station, TX (Ocean Drilling Program), 181-271.

, 1993c. Sites 867/868. In Sager, W.W., Winterer, E.L., Firth, J.V., et al., Proc. ODP, Init. Repts., 143: College Station, TX (Ocean Drilling Program), 273-296.

, 1993d. Site 878. In Premoli Silva, I., Haggerty, J., Rack, F., et al., Proc. ODP, Init. Repts., 144: College Station, TX (Ocean Drilling Program), 331-412.

van Wassbergen, R.J., 1993. Western Pacific guyots: summit geomorphology, sedimentology and structure of drowned Cretaceous carbonate platforms [Ph.D. dissert.]. Univ. of California San Diego, La Jolla, CA.

van Waasbergen, R.J., and Winterer, E.L., 1993. Summit geomorphology of Western Pacific guyots. In Pringle, M.S., Sager, W.W., Sliter, W.V., and Stein, S. (Eds.), The Mesozoic Pacific: Geology, Tectonics, and Volcanism. Am. Geophys. Union, Geophys. Monogr. Ser., 77:335-366.

Winterer, E.L., and Metzler, C.V., 1984. Origin and subsidence of guyots in Mid-Pacific Mountains. J. Geophys. Res., 89:9969-9979.

Date of initial receipt: 29 November 1993

Date of acceptance: 10 May 1994

Ms 143SR-243 


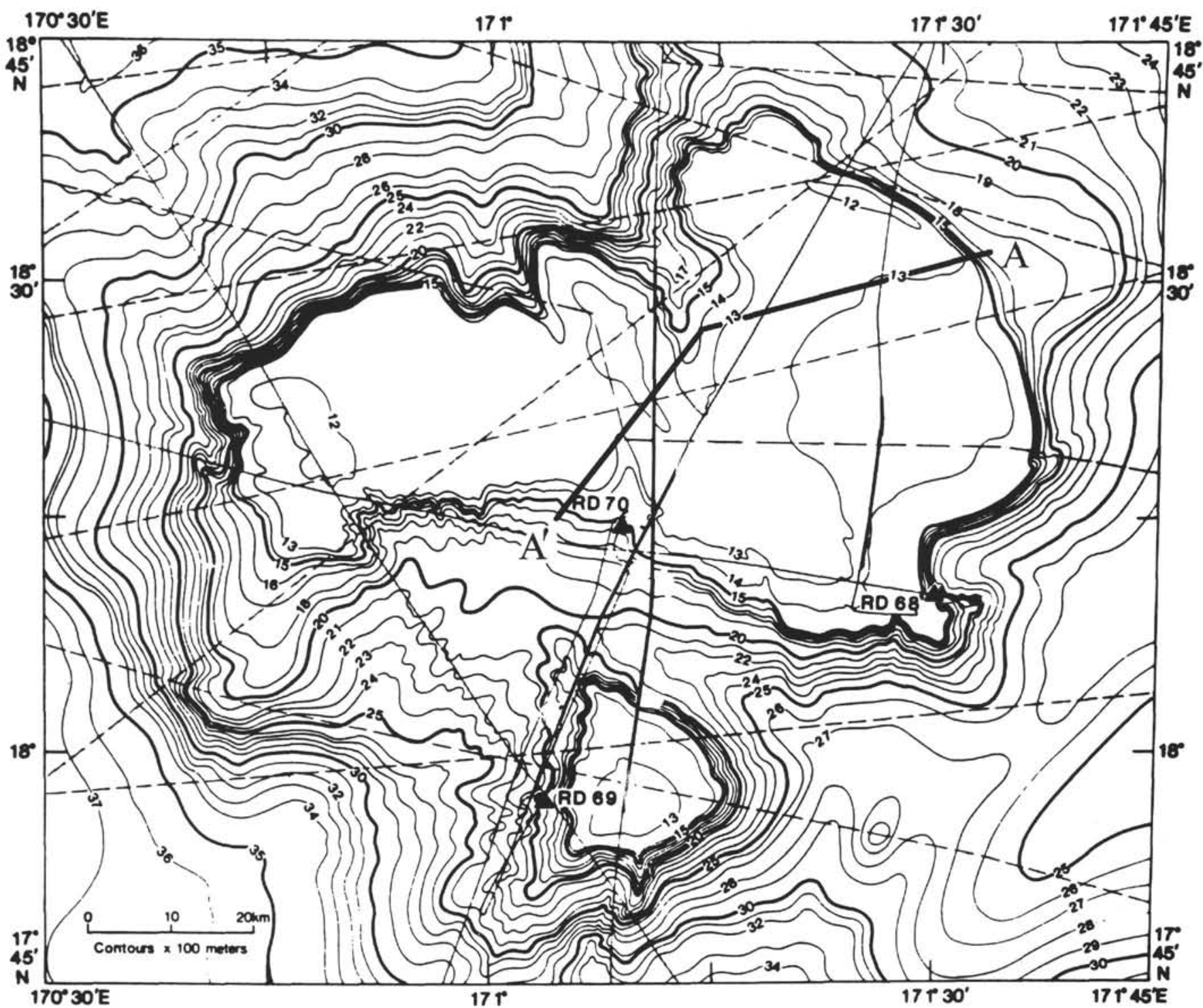

Figure 48. Bathymetric chart of Sio Guyot, from Nemoto and Kroenke (1985). The location of profile A-A', shown in Figure 49, is indicated. RD 68 through 70 are dredge locations.

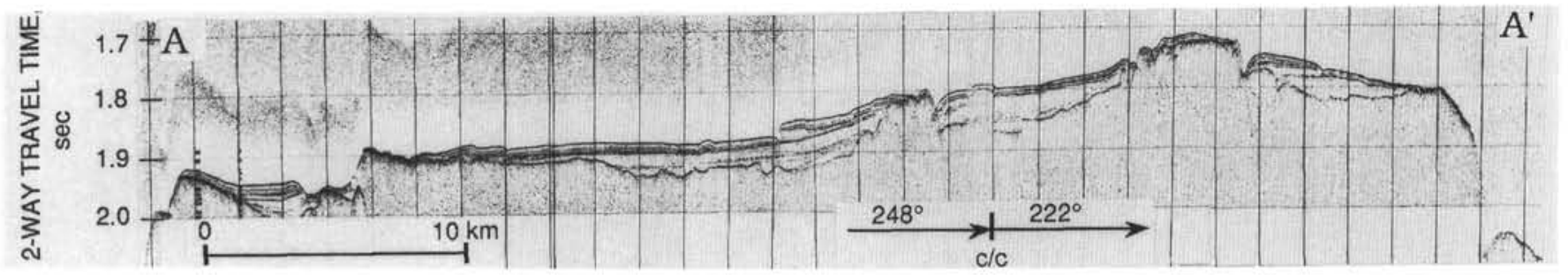

Figure 49.3.5-kHz profile across Sio Guyot along line A- $\mathrm{A}^{\prime}$ in Figure 48, showing the irregular surface of unconformity between pelagic sediments and the strata below. Note the near-vertical slope at the south (right) end of the highest-standing block. Vertical exaggeration at seafloor about $27 \times$. 


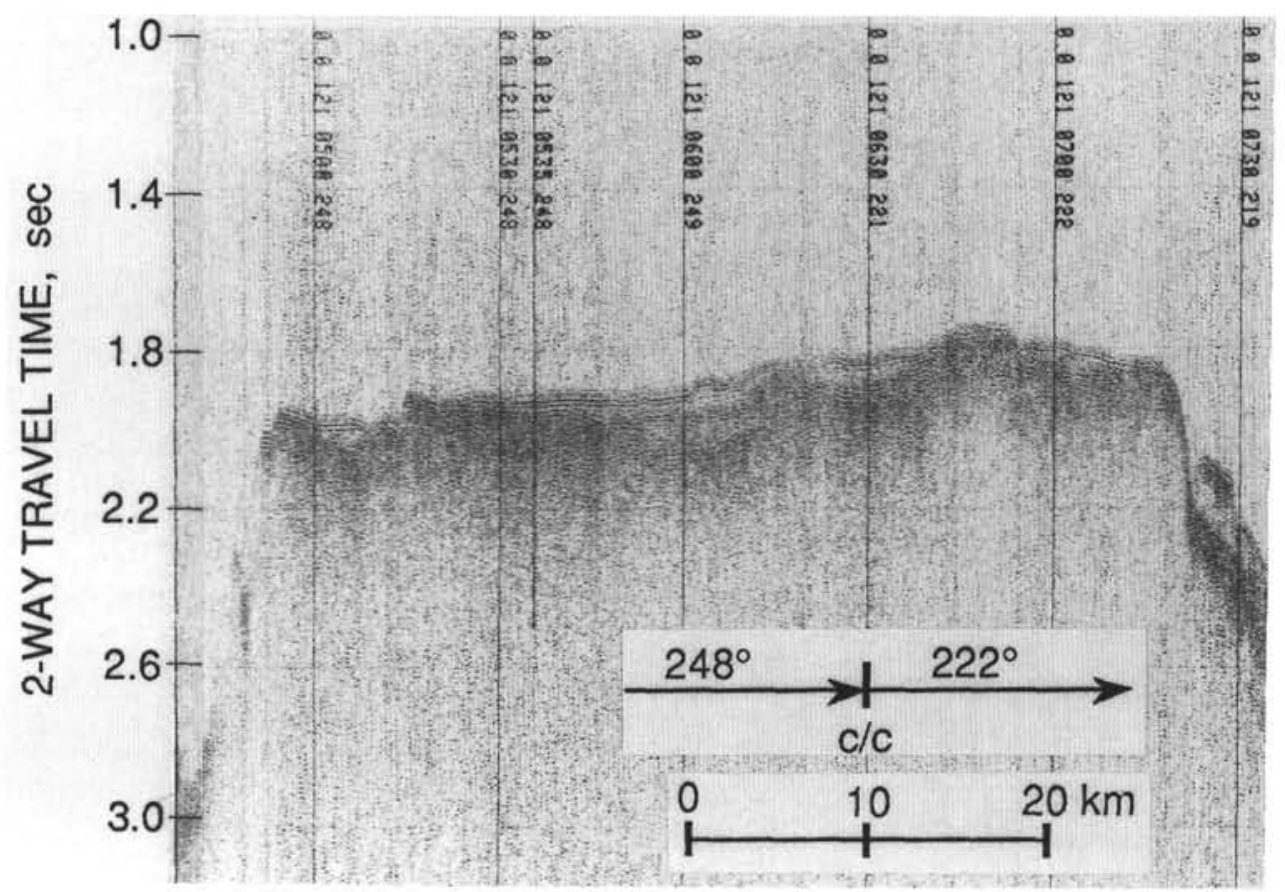

Figure 50. Seismic-reflection profile across Sio Guyot along line A-A' in Figure 48. Note that reflectors in the platform sequence are truncated at the unconformity, indicating that this is a surface of erosion. Profile taken from JOIDES Resolution during Leg 143. Vertical exaggeration at seafloor about $29 \times$. 